\title{
7. SITES 405 AND 406
}

\author{
The Shipboard Scientific Party ${ }^{1}$ \\ With a Special Contribution by \\ D. Mann, Dept. of Energy, Thames House South, London, U.K. \\ and an Appendix by \\ R. R. Harding
}

\section{SITE DATA, SITE 405}

Position: $55^{\circ} 20.18^{\prime} \mathrm{N}, 22^{\circ} 03.49^{\prime} \mathrm{W}$

Water Depth (sea level): 2958 corrected meters echo-sounding

Bottom Felt at: 2974 meters drill-pipe

Penetration: 407.0 meters

Number of Holes: 1

Number of Cores: 43

Total Core Recovered: 172.05

Percentage Core Recovery: 42.7 per cent

Oldest Sediment Cored:

Depth sub-bottom: 407.0 meters

Nature: Claystone

Age: Early Eocene

\section{Basement:}

Not reached

Principal Results: Site 405 was drilled at the foot of the east-west-trending transform fault which defines part of the southwest margin of the Rockall Plateau (Figure 1). The principal objective of the site (with Site 406) was to examine the structural and stratigraphic evolution of a transform margin also exposed to a subsequent phase of rifting and subsidence as recorded at Sites 403 and 404 . The site was cored continuously to a total sub-bottom depth of 407 meters.

Within the drilled section, two lithologic units and six sub-units were recognized. Unit $1(0-65 \mathrm{~m})$, which extends from the sea floor to the late Miocene/middle Eocene hiatus (43 m.y.), consists of marly foraminifer nannofossil ooze, foraminifer nannofossil ooze, and nannofossil ooze; it represents fragments of the Quaternary, lower Pliocene, and upper Miocene stratigraphic record. Unit $2(65-407 \mathrm{~m})$ consists in its upper part of foraminifer nannofossil ooze, nannofossil

'Lucien Montadert (Co-Chief Scientist), Institut Français du Pétrole, Rueil-Malmaison, France; David G. Roberts (Co-Chief Scientist), Institute of Oceanographic Sciences, Surrey, England; Gerard A. Auffret, Centre Océanologique de Bretagne, Brest, France; Wayne D. Bock, Rosenstiel School of Marine and Atmospheric Science, Miami, Florida; Pierre A. Dupeuble, Université de Rouen, Mont-Saint-Aignan, France; Ernest A. Hailwood, University of Southampton, Southampton, United Kingdom; William E. Harrison, University of Oklahoma, Norman, Oklahoma; Hideo Kagami, University of Tokyo, Tokyo, Japan; David N. Lumsden, Memphis State University, Memphis, Tennessee; Carla M. Müller, Geologisch-Paläontologisches Institut der Universität, Frankfurt am Main, Federal Republic of Germany (now at: Institut Français du Pétrole, Rueil-Malmaison, France); Detmar Schnitker, University of Maine, Walpole, Maine; Robert W. Thompson, Humboldt State University, Arcata, California; Thomas L. Thompson, University of Oklahoma, Norman, Oklahoma; and Peter P. Timofeev, USSR Academy of Sciences, Moscow, USSR. ooze, and siliceous nannofossil ooze; in its lower part, the principal lithologies are well-laminated siliceous mudstones with interbedded chert layers. The hole terminated in claystones of early Eocene age, in which dips of up to 30 degrees were recorded. Benthic foraminiferal assemblages of Eocene age are a mixture of bathyal and upper-slope to shelf species. The middle Eocene/late Miocene hiatus is considered to indicate a prolonged period of non-deposition and/or erosion at the site.

\section{SITE DATA, SITE 406}

Position: $55^{\circ} 15.50^{\prime} \mathrm{N}, 22^{\circ} 05.41^{\prime} \mathrm{W}$

Water Depth (sea level): 2907 corrected meters echo-sounding

Bottom Felt at: 2923 meters drill-pipe

Penetration: 831.5 meters

Number of Holes: 1

Number of Cores: 52

Total Core Recovered: 189.42

Percentage Core Recovery: 38.69 per cent

Oldest Sediment Cored:

Depth sub-bottom: 831.5 meters

Nature: Claystone

Age: Middle Eocene

\section{Basement:}

Not reached

Principal Results: Site 406 is situated about $8 \mathrm{~km}$ south of Site 405 and was drilled to provide, with Site 405 , a composite stratigraphic record of the history of a transform margin. The hole was also designed to penetrate the Pliocene to middle Eocene section missing at Site 405 . The hole was spot cored to a depth of 413.5 meters and then cored continuously to the final sub-bottom depth of 822.0 meters.

Hiatuses were found between the upper and middle Miocene, within the lower Miocene, between the middle Oligocene and the upper Eocene, and between the upper Eocene and the middle Eocene. Five lithologic units and three sub-units were recognized. Unit $1(0-71.5 \mathrm{~m})$ consists of rhythmically interbedded calcareous mud, marly foraminifer nannofossil ooze, and foraminifer nannofossil ooze. Unit 2 (110-557.5 m) comprises bluish white nannofossil ooze and gray siliceous chalk of Pliocene to middle Miocene age. Unit 3 (557.5-617.5 $\mathrm{m})$ of early Miocene to late-middle Oligocene age, consists principally of diatomaceous chalk with interbeds of calcareous diatomite. Unit $4(617.5-765.0 \mathrm{~m})$ of late Eocene age consists of calcareous chalks interbedded with diatomites. Slumping is common within the unit. Unit $5(765.0-822.0 \mathrm{~m})$ of middle Eocene age comprises marly calcareous chalk and limestone representing the uppermost part of the fan-like body observed on the seismic profiles. 


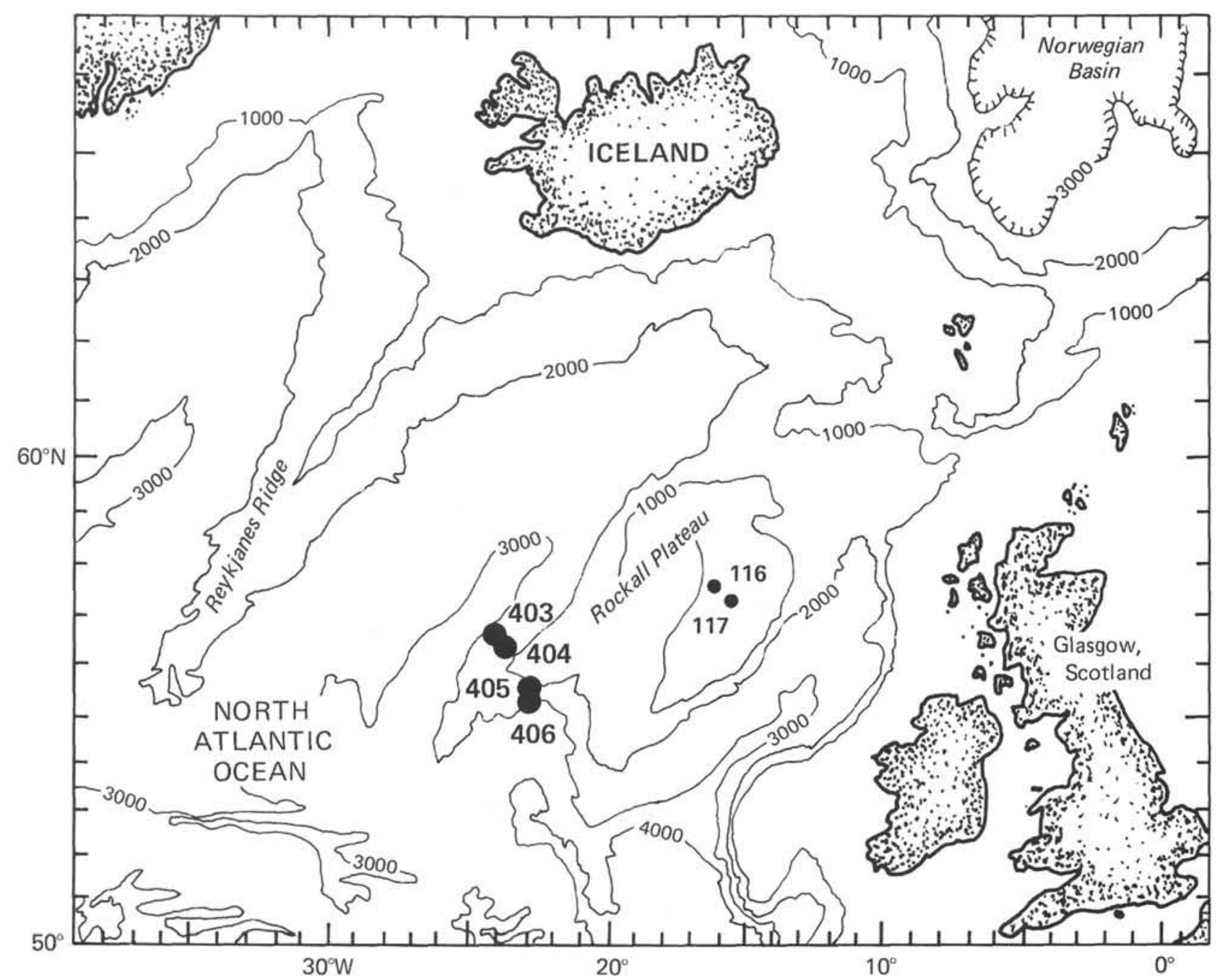

Figure 1. Northeast Atlantic bathymetry showing location of Sites 403, 404, 405, 406, 116, and 117.

The lower-middle Eocene sediments drilled at Sites 405 and 406 are interpreted as a large submarine fan built out from the foot of the transform fault in bathyal depths. The hiatuses are tentatively attributed to periods of intensified bottom circulation perhaps associated with wider ocean circulation changes. The alternations of carbonate and diatomite may include periodic local upwelling; slumping effects are attributed to bottom currents. The thick section of Miocene calcareous ooze is probably the product of sediment drifting. Seismic and paleobathymetric data suggest that $16 \mathrm{~km}$ of subaerial relict may have existed along the transform fault. The total relief of about $5.5 \mathrm{~km}$ was apparently created by Eocene time.

\section{BACKGROUND AND OBJECTIVES}

The regional geology and structure of the Rockall Plateau micro-continent were reviewed in the preceding chapter. Three distinct phases of rifting and spreading have structurally isolated the Rockall Plateau micro-continent. Preceded by the Kimmeridgian epeirogeny of northwest Europe, the first, in Early/Middle Cretaceous time, may have opened contemporaneously the Rockall Trough and Bay of Biscay. This spreading phase of unknown speed and duration, split the Greenland-Rockall-North America plate off Eurasia (Roberts, 1971; Roberts et al., 1973a; Roberts, 1974, 1975; Jones and Roberts, in preparation). By 73 m.y. spreading had ceased in the Rockall Trough and the axis shifted to the line of the Labrador Sea, spreading Greenland-Rockall away from North America and creating the Gibbs fracture zone (Vogt et al., 1971; Laughton, 1971; Le Pichon et al., 1972; Olivet et al., 1974; Roberts, 1974, 1975). In the final phase, followed by spreading at 53 to 55 m.y. about the incipient Reykjanes Ridge axis, rifting split Greenland and Rockall apart thereby completing isolation of the Rockall Plateau (Vogt et al., 1971; Laughton, 1971; Vogt and Avery, 1974; Roberts, 1974, 1975). On the Reykjanes Ridge, spreading decelerated from $1 \mathrm{~cm} / \mathrm{yr}$ between 55 and $38 \mathrm{~m} . \mathrm{y}$. to $0.7 \mathrm{~cm} / \mathrm{yr}$ between 38 and 10 $\mathrm{m} . \mathrm{y}$, and accelerated to its present rate of $1.1 \mathrm{~cm} / \mathrm{yr}$ at 10 m.y. (Vogt et al., 1971; Vogt and Avery, 1974).

Sites 405 and 406 are situated on and to the south of the prominent east-west scarp that forms part of the rectilinear southwest margin of the Rockall Plateau (Figures 1, 2). In the adjacent oceanic crust, the magnetic anomalies are younger westward, from anomaly 31-32 close to Lorien Bank to anomaly- 24 at $25^{\circ} 30^{\prime} \mathrm{W}$, but are truncated northward at the foot of the east-west scarp. The anomaly 


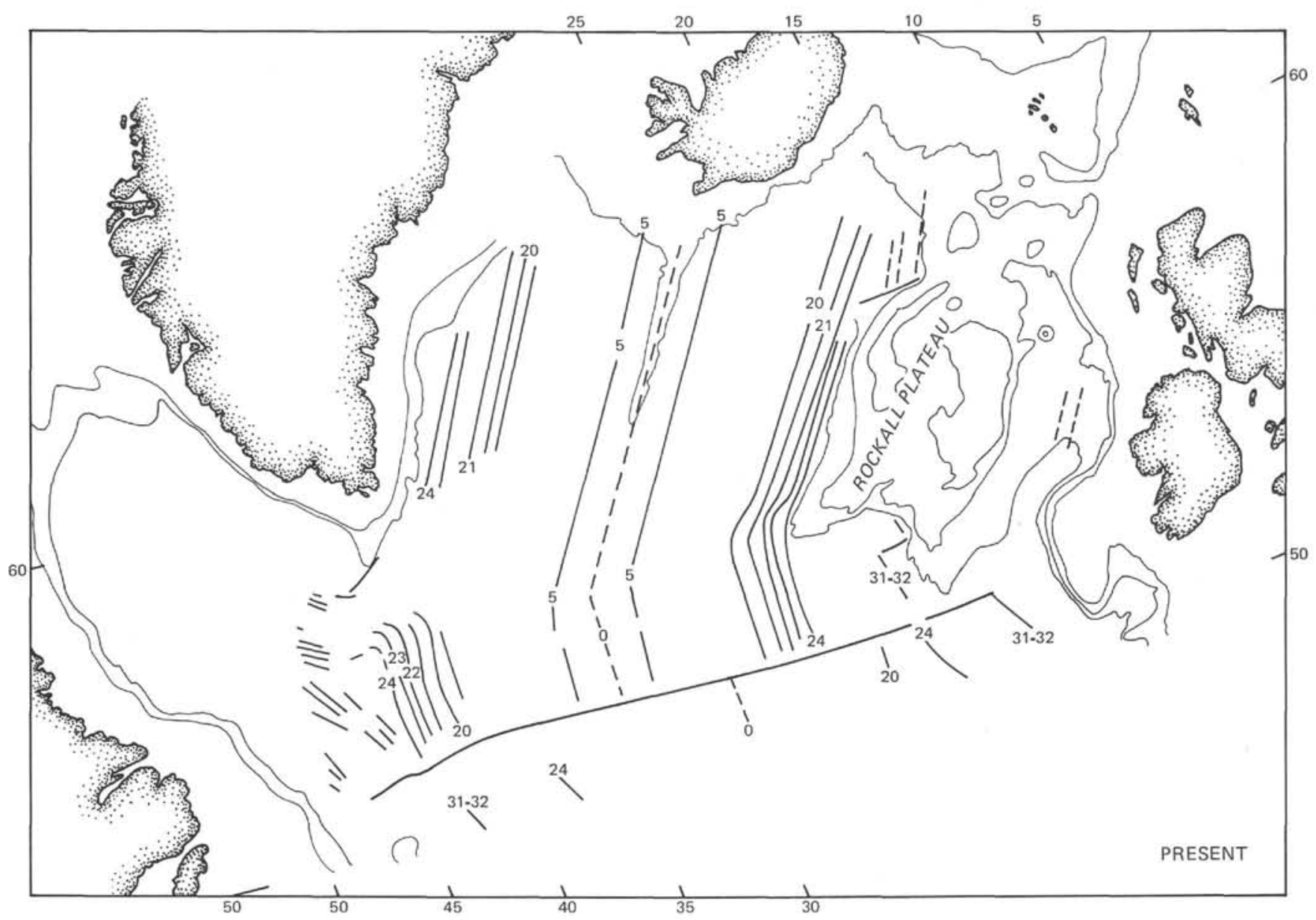

Figure 2. Magnetic anomalies in the North Atlantic Ocean.

data indicate that spreading began at $73 \mathrm{~m} . \mathrm{y}$. and that the east-west margin may have been a transform fault with an offset of 100 miles active between 73 and 55 m.y. during the early opening of the Labrador Sea (Olivet et al., 1973; Vogt and Avery, 1974; Roberts, 1974, 1975). Seismic profiles across the east-west margin (Roberts et al., this volume) show an underlying basement scarp with a relief of 3 to $4 \mathrm{~km}$ that trends parallel to the contemporaneous segment of the Gibbs fracture zone (Figures 2 to 5). Pre-drift reconstructions of the North Atlantic hint that the transform fault may have been controlled structurally by the eastward continuation of the Grenville Front (Roberts et al., 1973b). In contrast, the adjoining north-south margin was formed by rifting, presumably to become passive at the onset of spreading at 73 m.y. It should be noted that motion along the transform fault may have been partly contemporaneous with the rifting that initially formed the younger northeastsouthwest margin to the north.

The choice of Sites 405 and 406 was made from single-channel and 24-fold 48-trace seismic surveys made by the Institute of Oceanographic Sciences supplemented by single-channel seismic profiles of the Lamont-Doherty Geological Observatory and U.S. Navy Oceanographic Office (Ruddiman, 1972; Roberts, 1975; Roberts et al., this volume). From these data, isochron and structure maps show that the southwest margin of the Rockall Plateau is structured into a series of northeasterly trending basins that change course southward to converge with the transform fault.

The multichannel seismic section (Figure 5) shows a prominent basement fault scarp with a relief of about 3.5 seconds (two-way time). At the foot of the topographic scarp, presumed continental basement lies at about 0.5 seconds depth, but south of the scarp, presumed oceanic basement lies at about 4.0 seconds depth. Within the overlying section, five prominent reflectors are present. The strong flat-lying reflector 5 at about 1.0 seconds depth, previously considered to be the oceanic basement, is underlain by a sequence of strong flat-lying reflectors of unknown origin that infill the irregular oceanic basement. Above reflector 5, a prominent fan-like sedimentary wedge, defined by reflector 4 , thickens northward at about the fault and nearly outcrops at the base of the scarp. Reflectors 1, 2, and 3 in the uppermost part of the section pinch out northward against reflector 4 .

Site 406 was located at the southern edge of the channel aligned to the base of the fault scarp and drilling there was designed to penetrate to reflector 5 through the outer part of the fan-like body. Site 405 was situated at the base of the scarp for the purpose of penetrating through much of the inner part of the fan. Collectively, the two sites were drilled to yield a composite stratigraphic section to reflector 5 . 


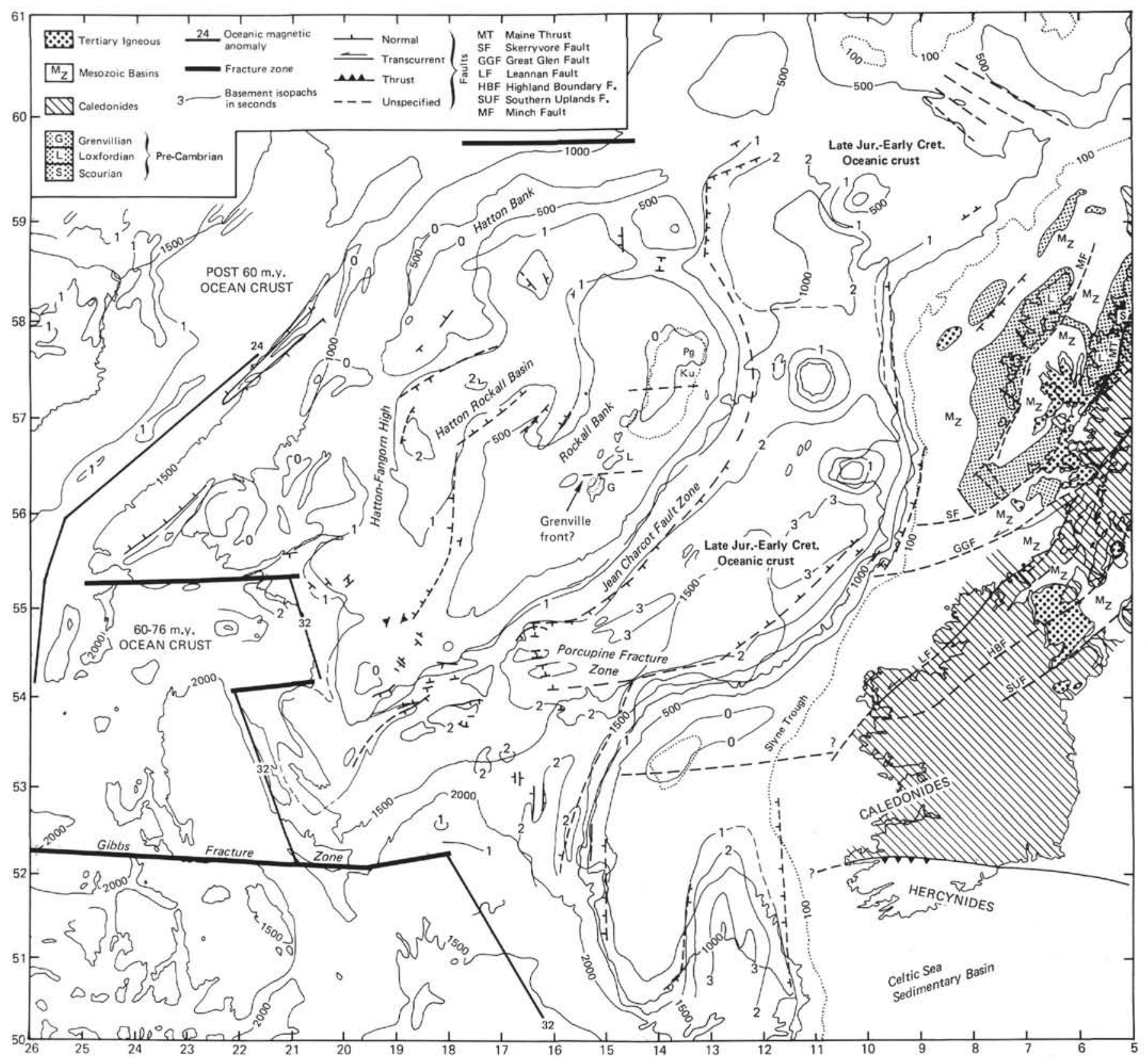

Figure 3. Main structural elements of the Rockall Plateau and Trough (from Roberts, 1975).

\section{Scientific Objectives}

The tectonic fabric of passive ocean margins can be broadly classified into rift and transform types.

The structure of a rifted margin typically consists of a number of tilted and rotated fault blocks often oriented sub-parallel to the margin. Active rifting only takes place during the "pull apart" of the continental lithosphere and ceases at the onset of spreading when the tectonic regime changes from extension to accretion, causing the rift margin to become passive and then subside through time.

In contrast, transform passive margins lie obliquely to the regional trend of the rift margin and are the loci of shear motion along offsets in the trailing edges of the diverging continents. Depending on the length of the offset, and rate of divergence or spreading apart of the continents, segments of transform margins may remain sites of active shear long after rifting has ceased and spreading has begun. Transform margins can become passive only when the offset trailing edges of the continents have moved past each other.

Although many passive margins are associated with transform faulting, little is known of the nature of contemporaneous and subsequent vertical movements on such faults and the changing thermal regime imposed by the juxtaposition of a continent and spreading mid-ocean ridge along a transform fault.

The principal objective of Sites 405 and 406, comprising a transect across a transform fault, was to examine the 


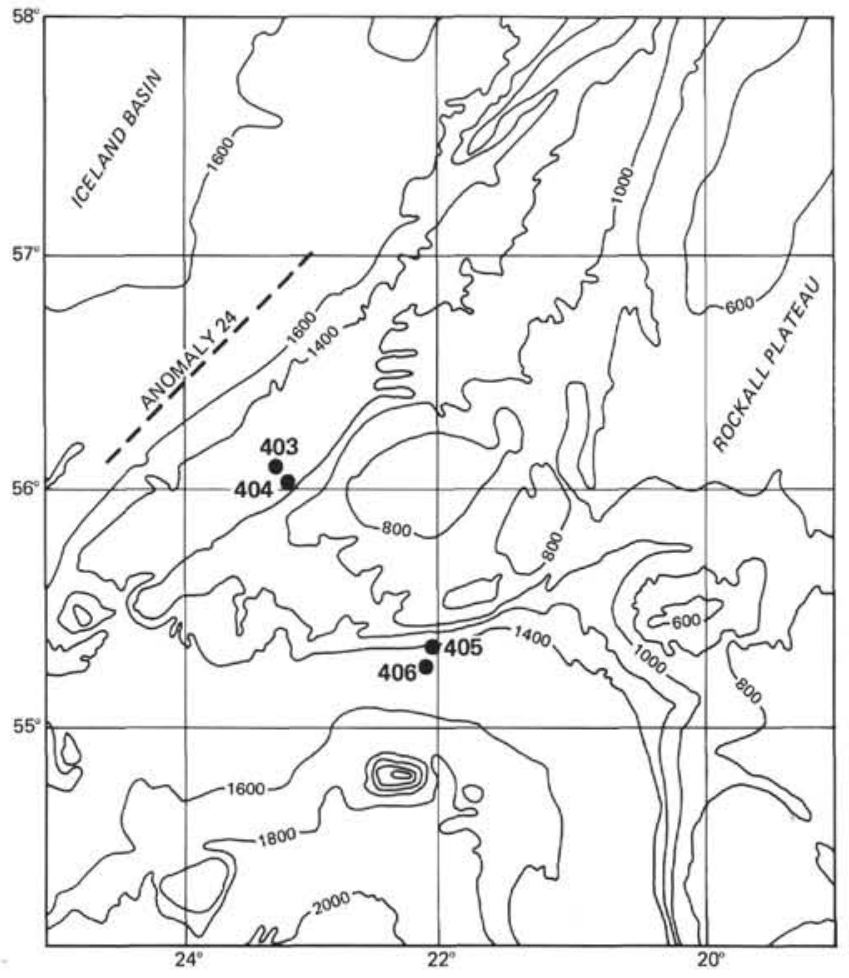

Figure 4. Bathymetry Sites 405 and 406, Rockall Plateau.

structural and stratigraphic evolution of a transform margin. Within this broadly stated objective, the following specific problems were to be examined.

\section{Rifting Environment}

The crust south of the transform fault is substantially older than that west of Sites 403 and 404 . The overlying sediments may therefore contain a record of the rifting and spreading that formed the younger margin to the north. Of particular interest was the paleobathymetry of the rift and transform margins.

\section{Unconformities}

Within the deeper section, several reflectors and unconformities are present that may be related to the rifting and transform episodes as well as to the subsidence history of the margin.

\section{Subsidence}

Little is known of the subsidence history of transform faults and the geological processes responsible for their substantial relief. Comparison with the results of Sites 403 and 404 would provide data on the role, if any, of vertical decoupling along transform faults.

\section{Comparative Lithofacies Studies}

The prime objective was to examine the factors controlling the facies of sediments deposited contemporaneously on rift and transform margins.

\section{Paleoceanography}

Changes in bottom water circulation during the Tertiary that have resulted in part from subsidence of the Iceland-Faeroe Ridge, have profoundly influenced sediment distribution and deposition in the North Atlantic Ocean. The paleontologic and stratigraphic record of the Tertiary at Site 406 would provide insight into the nature and timing of these changes.

\section{Diagenesis}

It was intended to examine the influence on the diagenesis of the sediments by the rapidly changing thermal conditions on a transform margin.

\section{Paleomagnetism}

The objective was to correlate the magnetic reversal history with the biostratigraphic data in the lower Tertiary sequence especially with reference to anomalies 20 to 24 .

\section{Well Logging}

It was hoped to use the logging results to correlate the deeper section of Sites 405 and 406 and to correlate the log parameters with the seismic data, physical properties data, and lithologies.

\section{SITE APPROACH AND DRILLING OPERATIONS}

\section{Site 405}

After steaming eastward from Site 404, Glomar Challenger altered course to 178 degrees at 0945 hours on 29 June to directly cross the site (Figure 6). The vessel passed east of the site at 1345 hours and, at 1445 hours, course was altered to intercept the site position at the foot of the scarp. On identifying the site with the PDR and shipboard seismic profile, a $13.5-\mathrm{kHz}$ beacon was deployed at 1547 hours.

Site 405 was spudded at 0400 hours on 30 June in 2974 meters depth. An 8.58-meter core of Pleistocene foraminifer nannofossil ooze was cut at the mudline and the hole was thereafter continuously cored to TD. Ten barrels of 8.9 wt 6.7 vis mud were spotted at 0902 hours. Some problems were experienced with the core barrel sticking at 106 meters above the pipe shoe. Following zero core recovery in Cores 20 and 21, a further 10 barrels of mud were spotted and a sock was inserted in the core catcher to contain unconsolidated sediments. Recovery improved slightly, but remained poor at less than 1 meter. Subsequently, core recovery improved to about 40 per cent on penetrating more indurated claystones at 283.0 meters. Drilling terminated in lower Eocene claystones at 407.0 meters at 1043 hours on 2 July (Table 1). Preparations for logging began by wiping the hole clean and spotting 20 barrels of mud. The bit release tool was then run-in and the bit released at 3381 meters ( $407.0 \mathrm{~m}$ sub-sea) at 1410 hours. After filling the hole with 155 barrels of 8.9 wt 6.7 vis mud, the string was pulled back to 3092 meters sub-sea. The gamma-sonic-caliper log was run-in first, but was stopped by a "bridge" at 3213 meters. Following the repeated 

SONOBUOY LAUNCHED
S $4650 \downarrow 4700 \downarrow 4750$ \
4900\%
4950
5000
4650
1
-0.0 (n)
$-1.0$
$\begin{array}{ll}V & V \\ V^{5150} & 5200\end{array}$

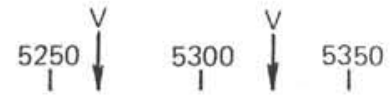

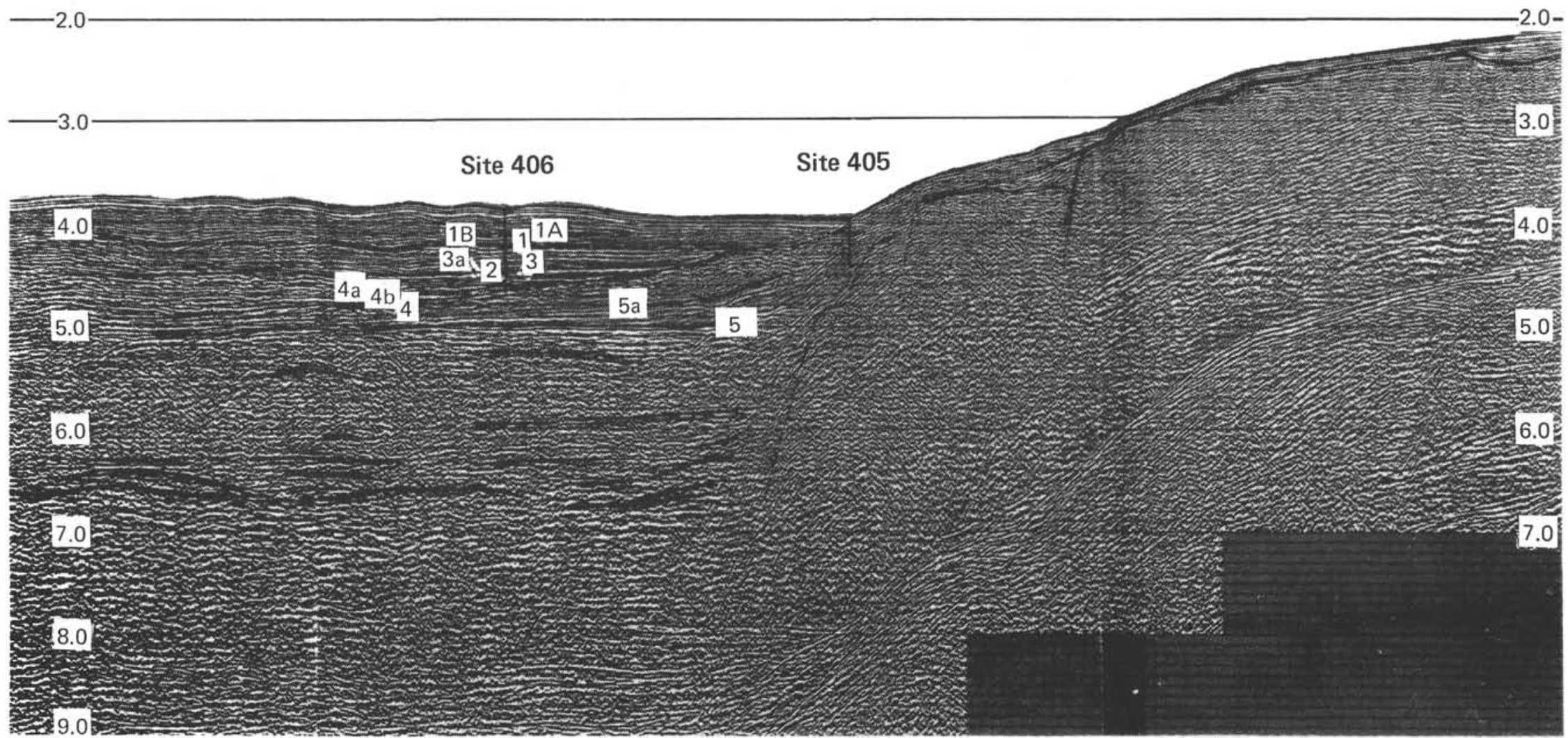

Figure 5. Multichannel seismic profile IPOD 76-2 through Sites 405 and 406. 


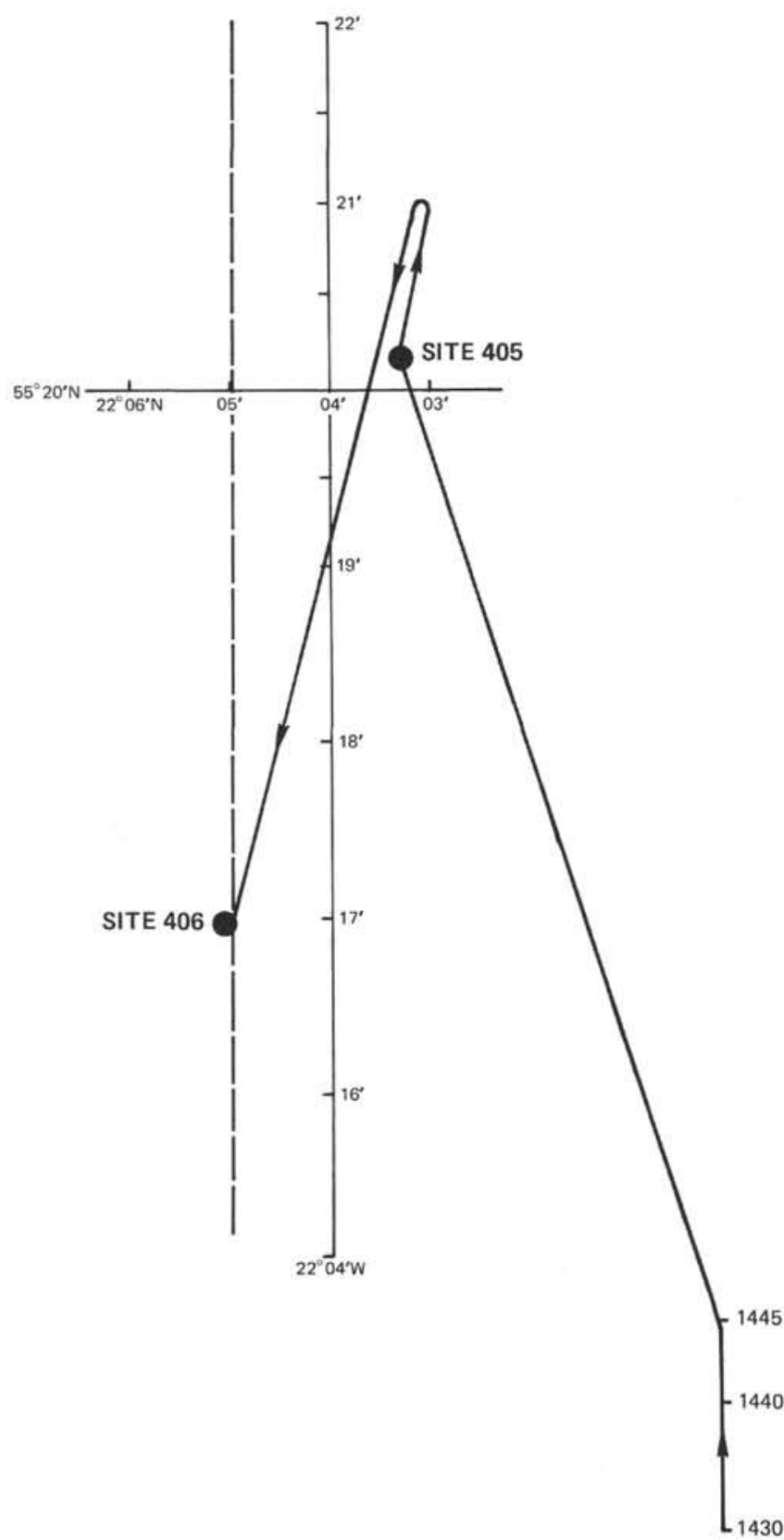

Figure 6. Approach of the Glomar Challenger to Sites 405 and 406.

failure of attempts to spud, the tool was retrieved and at 1830 hours, a wiper run was made to clean out the bridge. After spotting a further 200 barrels of 8.9 wt 6.2 vis mud, logging began again and gamma-sonic-caliper, gammainduction, and gamma-density neutron logs were run without incident. Pulling out of the hole began at 0800 hours on 3 July and the mudline was cleared at 0810 hours. Although the pipe racker had to be repaired during recovery of the drill string, the rig floor was secured by 1400 hours on 3 July, when the vessel departed for Site 406.

\section{Site 406}

Glomar Challenger departed Site 405 for Site 406, some 5 miles further south at 1400 hours on 3 July (Figure 6).
Although Site 406 had been previously crossed during the approach to Site 405 , the seismic gear was again streamed as a further check on position. After leaving Site 405, Glomar Challenger headed north before executing a Williamson turn to cross the beacon at Site 405. At 1521 hours, a $16-\mathrm{kHz}$ beacon was deployed while crossing Site 406 and the geophysical gear brought on board. At 1620 hours, the vessel was positioning in automatic mode.

The site was spudded at 2230 hours in 2923 meters water depth and a 4.88-meter core of Pleistocene foraminifer nannofossil ooze cut at the mudline. Because the Quaternary through Pliocene section had been continuously cored at Site 405, Site 406 was spot cored at 62.0, 138.0, 214.0 , and 318.5 meters. Heat flow measurements were made after each of these cores. The hole was cored continuously from 328.0 meters to TD and a further heat flow measurement was made at 413.5 meters sub-sea. After Core 44 had been retrieved, the bit apparently became plugged in nannofossil chalk and 15 barrels of $8.9 \mathrm{wt} 6.5 \mathrm{vis}$ mud were spotted after running in the center bit. At 1920 hours on 7 July, the float valve stuck in the open position and the center bit was again run-in to unplug the bit. Although the pressure dropped, the float valve remained open. The core barrel was dropped again and a further 15 barrels of mud spotted at 2015 hours. The inner barrel failed to seat and, at 2040 hours, one single barrel was set back prior to retrieving the core barrel. Further unsuccessful attempts to seat the inner barrel were made between 2133 and 2230 hours. At 2300 hours, drilling was terminated at a sub-bottom depth of 8315 meters. After dropping the center bit, the hole was wiped and mud spotted in preparation for logging. On running in hole to retrieve the center bit at 0420 hours on 8 July, the center bit and core barrel could not be located. The cause of the loss of the center bit and inner barrel, and the seating problems experienced earlier, may have been that the bit release was operated prematurely. At 0635 hours, 300 barrels of 8.9 wt 6.5 vis mud were spotted and the pipe pulled back to logging depth at 3027 meters. At 0918 , the gamma-sonic-caliper log was run and a variable density log made. Successive logging runs were made using the gamma-neutron-density and induction tools. Logging was completed at 2300 hours (Table 2), the drill string was recovered and the rig floor secured by 0945 hours on 9 July when Glomar Challenger departed Site 406 for Aberdeen, Scotland.

\section{LITHOLOGY, SITE 405}

Site 405 was continuously cored from the sea bed at 2974 meters to a sub-bottom depth of 407 meters. The uppermost Quaternary section consists of interbedded yellowish brown, marly foraminifer nannofossil ooze and light gray foraminifer nannofossil ooze, both of which contain ice-rafted pebbles. The section is separated from the thin underlying unit of upper Miocene/lower Pliocene nannofossil ooze by a short hiatus ( $3 \mathrm{~m} . \mathrm{y}$.) corresponding to the upper Pliocene. A major hiatus of about 40 m.y. occurs at a sub-bottom depth of about 60 to 65 meters so that Miocene ooze rests on grayish orange nannofossil ooze of early middle Eocene age. Rapidly deposited olive-gray calcareous mudstone of definite early Eocene age was first encountered at a sub-bottom depth of just over 100 meters 
TABLE 1

Coring Summary, Site 405

\begin{tabular}{|c|c|c|c|c|c|c|c|}
\hline Core & $\begin{array}{c}\text { Date } \\
\text { June/July } \\
1976\end{array}$ & Time & $\begin{array}{l}\text { Depth From Drill } \\
\text { Floor }(\mathrm{m})\end{array}$ & $\begin{array}{c}\text { Depth Below Sea } \\
\text { Floor }(\mathrm{m})\end{array}$ & $\begin{array}{l}\text { Length } \\
\text { Cored } \\
\text { (m) }\end{array}$ & $\begin{array}{l}\text { Length } \\
\text { Recovered } \\
\text { (m) }\end{array}$ & $\begin{array}{c}\text { Recovered } \\
(\%)\end{array}$ \\
\hline 1 & 30 & 0450 & $2974.0-2982.0$ & $0-8.0$ & 8.0 & 8.58 & $100+$ \\
\hline 2 & 30 & 0552 & $2982.0-2991.5$ & $8.0-17.5$ & 9.5 & 9.02 & 95 \\
\hline 3 & 30 & 0644 & $2991.5-3001.0$ & $17.5-27.0$ & 9.5 & 4.04 & 43 \\
\hline 4 & 30 & 0741 & $3001.0-3010.5$ & $27.0-36.5$ & 9.5 & 2.68 & 28 \\
\hline 5 & 30 & 0902 & $3010.5-3020.0$ & $36.5-46.0$ & 9.5 & 6.25 & 66 \\
\hline 6 & 30 & 1023 & $3020.0-3029.5$ & $46.0-55.5$ & 9.5 & 1.65 & 17 \\
\hline 7 & 30 & 1132 & $3029.5-3039.0$ & $55.5-65.0$ & 9.5 & 0.45 & 4.7 \\
\hline 8 & 30 & 1240 & $3039.0-3048.5$ & $65.0-74.5$ & 9.5 & 9.58 & 100 \\
\hline 9 & 30 & 1333 & $3048.5-3058.0$ & $74.5-84.0$ & 9.5 & 2.97 & 31 \\
\hline 10 & 30 & 1435 & $3058.0-3067.5$ & $84.0-93.5$ & 9.5 & 9.63 & 100 \\
\hline 11 & 30 & 1540 & $3067.5-3072.0$ & $93.5-103.0$ & 9.5 & 0.69 & 7.2 \\
\hline 12 & 30 & 1633 & $3072.0-3086.5$ & $103.0-112.5$ & 9.5 & 9.67 & 100 \\
\hline 13 & 30 & 1717 & $3086.5-3096.0$ & $112.5-122.0$ & 9.5 & 9.59 & 100 \\
\hline 14 & 30 & 1838 & $3096.0-3105.5$ & $122.0-131.5$ & 9.5 & 3.18 & 33 \\
\hline 15 & 30 & 1940 & $3105.5-3115.0$ & $131.5-141.0$ & 9.5 & 9.78 & 100 \\
\hline 16 & 30 & 2041 & $3115.0-3124.5$ & $141.0-150.5$ & 9.5 & 9.74 & 100 \\
\hline 17 & 30 & 2145 & $3124.5-3134.0$ & $150.5-160.0$ & 9.5 & 8.64 & 91 \\
\hline 18 & 30 & 2357 & $3134.0-3143.5$ & $160.0-169.5$ & 9.5 & 0.85 & 8.9 \\
\hline 19 & 1 & 0101 & $3143.5-3153.0$ & $169.5-179.0$ & 9.5 & 4.5 & 47 \\
\hline 20 & 1 & 0159 & $3153.0-3162.5$ & $179.0-188.5$ & 9.5 & 0 & 0 \\
\hline 21 & 1 & 0255 & $3162.5-3172.0$ & $188.5-198.0$ & 9.5 & 0 & 0 \\
\hline 22 & 1 & 0405 & $3172.0-3181.5$ & $198.0-207.5$ & 9.5 & 0.04 & 0.4 \\
\hline 23 & 1 & 0500 & $3181.5-3191.0$ & $207.5-217.0$ & 9.5 & 0.06 & 0.6 \\
\hline 24 & 1 & 0611 & $3191.0-3200.5$ & $217.0-226.5$ & 9.5 & 0 & 0 \\
\hline 25 & 1 & 0720 & $3200.5-3210.0$ & $226.5-236.0$ & 9.5 & 0.97 & 10 \\
\hline 26 & 1 & 0830 & $3210.0-3219.5$ & $236.0-245.5$ & 9.5 & 0.20 & 2 \\
\hline 27 & 1 & 0935 & $3219.5-3229.0$ & $245.5-255.0$ & 9.5 & 0.81 & 8.5 \\
\hline 28 & 1 & 1100 & $3229.0-3238.5$ & $255.0-264.5$ & 9.5 & 0.67 & 7 \\
\hline 29 & 1 & 1202 & $3238.5-3248.0$ & $264.5-274.0$ & 9.5 & 0.32 & 3.3 \\
\hline 30 & 1 & 1324 & $3248.0-3257.5$ & $274.0-283.5$ & 9.5 & 0.17 & 1.7 \\
\hline 31 & 1 & 1511 & $3257.5-3267.0$ & $283.5-293.0$ & 9.5 & 4.10 & 43 \\
\hline 32 & 1 & 1650 & $3267.0-3276.5$ & $293.0-302.5$ & 9.5 & 4.35 & 45.7 \\
\hline 33 & 1 & 1818 & $3276.5-3286.0$ & $302.5-312.0$ & 9.5 & 1.41 & 15 \\
\hline 34 & 1 & 2002 & $3286.0-3295.5$ & $312.0-321.5$ & 9.5 & 3.36 & 35 \\
\hline 35 & 1 & 2250 & $3295.5-3305.0$ & $321.5-331.0$ & 9.5 & 1.70 & 18 \\
\hline 36 & 2 & 0105 & $3305.0-3314.5$ & $331.0-340.5$ & 9.5 & 4.10 & 43 \\
\hline 37 & 2 & 0235 & $3314.5-3324.0$ & $340.5-350.0$ & 9.5 & 2.55 & 27 \\
\hline 38 & 2 & 0430 & $3324.0-3333.5$ & $350.0-359.5$ & 9.5 & 4.56 & 48 \\
\hline 39 & 2 & 0530 & $3333.5-3343.0$ & $359.5-369.0$ & 9.5 & 3.65 & 38 \\
\hline 40 & 2 & 0640 & $3343.0-3352.5$ & $369.0-378.5$ & 9.5 & 3.25 & 34 \\
\hline 41 & 2 & 0750 & $3352.5-3362.0$ & $378.5-388.0$ & 9.5 & 8.88 & 93 \\
\hline 42 & 2 & 0912 & $3362.0-3371.5$ & $388.0-397.5$ & 9.5 & 5.59 & 59 \\
\hline 43 & 2 & 1042 & $3371.5-3381.0$ & $397.5-407.0$ & 9.5 & 9.82 & $100+$ \\
\hline Total & & & & & $\overline{407.0}$ & $\overline{172.05}$ & $\overline{42.7}$ \\
\hline
\end{tabular}

and, basically, this same lithology with minor variations persists to the bottom of the hole. The upper part of this mudstone sequence contains a significant admixture of siliceous biogenous remains and the central part (170 to 260 m) contains pebbles and cobbles of various igneous and metamorphic lithologies which may represent material slumped from the adjacent fault scarp. The lowermost 150 meters of section penetrated consists of dark greenish gray, laminated to bioturbated mudstone, parts of which have been extensively silicified and contain interbedded chert layers. Traces of volcaniclastic material were encountered near the base of the section.

Two main lithologic units and six sub-units (Figure 7) are distinguished within the section as indicated in Table 3. These are described below from the top down.

\section{Unit 1}

Lithologic Unit 1 extends from the sea floor to the prominent late Miocene/early to mid Eocene hiatus at a sub-bottom depth of approximately 65 meters. The unit is characterized by an upward trend from relatively pure biogenic calcareous ooze at the base (Sub-unit 1B) to interbedded ooze and mud to the top (Sub-unit 1A). Ice-rafted pebbles of varying lithologies occur throughout the section.

\section{Sub-Unit 1A}

Yellowish brown marly foraminifer nannofossil ooze and very light gray to greenish gray foraminifer nannofossil ooze constitute the principal lithologies found in this 
TABLE 2

Coring Summary, Site 406

\begin{tabular}{|c|c|c|c|c|c|c|c|}
\hline Core & $\begin{array}{c}\text { Date } \\
\text { July } 1976\end{array}$ & Time & $\begin{array}{l}\text { Depth From Drill } \\
\text { Floor }(\mathrm{m})\end{array}$ & $\begin{array}{l}\text { Depth Below Drill } \\
\text { Floor }(\mathrm{m})\end{array}$ & $\begin{array}{l}\text { Length } \\
\text { Cored } \\
\text { (m) }\end{array}$ & $\begin{array}{l}\text { Length } \\
\text { Recovered } \\
\text { (m) }\end{array}$ & $\begin{array}{c}\text { Recovered } \\
(\%)\end{array}$ \\
\hline 1 & 3 & 2313 & $2911.0-2916.0$ & $0-5.0$ & 5.0 & 4.88 & 97.6 \\
\hline 2 & 4 & 0209 & $2973.0-2982.5$ & $62.0-71.5$ & 9.5 & 5.82 & 61.2 \\
\hline 3 & 4 & 0600 & $3049.0-3058.5$ & $138.0-147.5$ & 9.5 & 1.28 & 13.4 \\
\hline 4 & 4 & 0945 & $3125.0-3134.5$ & $214.0-223.5$ & 9.5 & 2.84 & 29.8 \\
\hline 5 & 4 & 1354 & $3134.5-3239.0$ & $318.5-328.0$ & 9.5 & 0.18 & 1.8 \\
\hline 6 & 4 & 1618 & $3239.0-3248.5$ & $328.0-337.5$ & 9.5 & 3.1 & 32.6 \\
\hline 7 & 4 & 1736 & $3248.5-3258.0$ & $337.5-347.0$ & 9.5 & 6.35 & 66.8 \\
\hline 8 & 4 & 1845 & $3258.0-3267.5$ & $347.0-356.5$ & 9.5 & 9.69 & 100 \\
\hline 9 & 4 & 2206 & $3324.5-3334.0$ & $413.5-423.0$ & 9.5 & 2.38 & 25.0 \\
\hline 10 & 5 & 0023 & $3334.0-3343.5$ & $423.0-432.5$ & 9.5 & 1.21 & 12.7 \\
\hline 11 & 5 & 0126 & $3343.5-3353.0$ & $432.5-442.0$ & 9.5 & 1.14 & 12.0 \\
\hline 12 & 5 & 0240 & $3353.0-3362.5$ & $442.0-451.5$ & 9.5 & 2.34 & 24.6 \\
\hline 13 & 5 & 0343 & $3362.5-3372.0$ & $451.5-461.0$ & 9.5 & 8.31 & 87.4 \\
\hline 14 & 5 & 0449 & $3372.0-3381.5$ & $461.0-470.5$ & 9.5 & 3.0 & 31.5 \\
\hline 15 & 5 & 0600 & $3381.5-3391.0$ & $470.5-480.0$ & 9.5 & 2.69 & 28.3 \\
\hline 16 & 5 & 0710 & $3391.0-3400.5$ & $480.0-489.5$ & 9.5 & 3.9 & 41.0 \\
\hline 17 & 5 & 0805 & $3400.5-3410.0$ & $489.5-499.0$ & 9.5 & 2.04 & 21.4 \\
\hline 18 & 5 & 1006 & $3410.0-3419.5$ & $499.0-508.5$ & 9.5 & 0.41 & 4.2 \\
\hline 19 & 5 & 1112 & $3419.5-3429.0$ & $508.5-518.0$ & 9.5 & 0.84 & 8.8 \\
\hline 20 & 5 & 1218 & $3429.0-3438.5$ & $518.0-527.5$ & 9.5 & 4.04 & 42.5 \\
\hline 21 & 5 & 1329 & $3438.5-3448.0$ & $527.5-537.0$ & 9.5 & 3.82 & 40.2 \\
\hline 22 & 5 & 1450 & $3448.0-3457.5$ & $537.0-546.5$ & 9.5 & 1.13 & 11.9 \\
\hline 23 & 5 & 1556 & $3457.5-3467.0$ & $546.5-556.0$ & 9.5 & 5.32 & 56.0 \\
\hline 24 & 5 & 1719 & $3467.0-3476.5$ & $556.0-565.5$ & 9.5 & 2.92 & 30.7 \\
\hline 25 & 5 & 1847 & $3476.5-3486.0$ & $565.5-575.0$ & 9.5 & 1.28 & 13.5 \\
\hline 26 & 5 & 2002 & $3486.0-3495.5$ & $575.0-584.5$ & 9.5 & 0.25 & 2.6 \\
\hline 27 & 5 & 2114 & $3495.5-3505.0$ & $584.5-594.0$ & 9.5 & 5.3 & 55 \\
\hline 28 & 5 & 2218 & $3505.0-3514.5$ & $594.0-603.5$ & 9.5 & 2.02 & 21.3 \\
\hline 29 & 5 & 2338 & $3514.5-3524.0$ & $603.5-613.0$ & 9.5 & 5.31 & 55.9 \\
\hline 30 & 6 & 0045 & $3524.0-3533.5$ & $613.0-622.5$ & 9.5 & 6.0 & 63.1 \\
\hline 31 & 6 & 0146 & $3533.5-3543.0$ & $622.5-632.0$ & 9.5 & 6.94 & 73.0 \\
\hline 32 & 6 & 0252 & $3543.0-3552.5$ & $632.0-641.5$ & 9.5 & 6.98 & 73.4 \\
\hline 33 & 6 & 0358 & $3552.5-3562.0$ & $641.5-651.0$ & 9.5 & 5.25 & 55.3 \\
\hline 34 & 6 & 0520 & $3562.0-3571.5$ & $651.0-660.5$ & 9.5 & 4.65 & 48.9 \\
\hline 35 & 6 & 0630 & $3571.5-3581.0$ & $660.5-670.0$ & 9.5 & 2.12 & 22.3 \\
\hline 36 & 6 & 0800 & $3581.0-3590.5$ & $670.0-679.5$ & 9.5 & 4.26 & 44.8 \\
\hline 37 & 6 & 1005 & $3590.5-3600.0$ & $679.5-689.0$ & 9.5 & 6.85 & 72.1 \\
\hline 38 & 6 & 1207 & $3600.0-3609.5$ & $689.0-698.5$ & 9.5 & 7.23 & 76.1 \\
\hline 39 & 6 & 1353 & $3609.5-3619.0$ & $698.5-708.0$ & 9.5 & 7.16 & 75.3 \\
\hline 40 & 6 & 1541 & $3619.0-3628.5$ & $708.0-717.5$ & 9.5 & 4.18 & 44 \\
\hline 41 & 6 & 1828 & $3628.5-3638.0$ & $717.5-727.0$ & 9.5 & 8.39 & 88.3 \\
\hline 42 & 6 & 2100 & $3638.0-3647.5$ & $727.0-736.5$ & 9.5 & 5.04 & 53 \\
\hline 43 & 6 & 2344 & $3647.5-3657.0$ & $736.5-746.0$ & 9.5 & 0.10 & 1.05 \\
\hline 44 & 7 & 0146 & $3657.0-3666.5$ & $746.0-755.5$ & 9.5 & 0.14 & 1.4 \\
\hline 45 & 7 & 0426 & $3666.5-3676.0$ & $755.5-765.0$ & 9.5 & 6.0 & 69 \\
\hline 46 & 7 & 0620 & $3676.0-3685.5$ & $765.0-774.5$ & 9.5 & 4.56 & 48 \\
\hline 47 & 7 & 0815 & $3685.5-3695.0$ & $774.5-784.0$ & 9.5 & 6.30 & 66.3 \\
\hline 48 & 7 & 0930 & $3695.0-3704.5$ & $784.0-793.5$ & 9.5 & 5.22 & 54.7 \\
\hline 49 & 7 & 1150 & $3704.5-3714.0$ & $793.5-803.0$ & 9.5 & 2.08 & 21.8 \\
\hline 50 & 7 & 1520 & $3714.0-3723.5$ & $803.0-812.5$ & 9.5 & 0.09 & .9 \\
\hline 51 & 7 & 1708 & $3723.5-3733.0$ & $812.5-822.0$ & 9.5 & 0.12 & 1.2 \\
\hline 52 & 7 & 1900 & $3733.0-3742.5$ & $822.0-831.5$ & 9.5 & 0.18 & 1.8 \\
\hline Total & & & & & 489.5 & $\overline{189.42}$ & 38.69 \\
\hline
\end{tabular}

sub-unit. Marly ooze dominates in the upper (Core 1) and lower (Core 5) parts of the section whereas the two lithologies alternate in beds on the order of 30 to $60 \mathrm{~cm}$ thick in the middle part. Occasional interbeds of dark yellowish brown calcareous mud and light gray nannofossil ooze also occur in this part of the section. Most of the cores were intensely disturbed by drilling, but Cores 2 and 3 give the impression of repeated gradational sequences which pass upward from relatively pure calcareous ooze to marly ooze to calcareous mud over intervals of approximately one meter.

Bomb, Leco, and X-ray analyses indicate that the carbonate content ranges from essentially zero to as high as 92 per cent in the various beds within this sub-unit with the most pronounced fluctuations occurring toward the top (Cores 1 and 2). The clay mineral suite (Latouche, this volume) is characterized by roughly equal parts $(25-50 \%)$ of smectite and illite with a consistent admixture of chlorite 


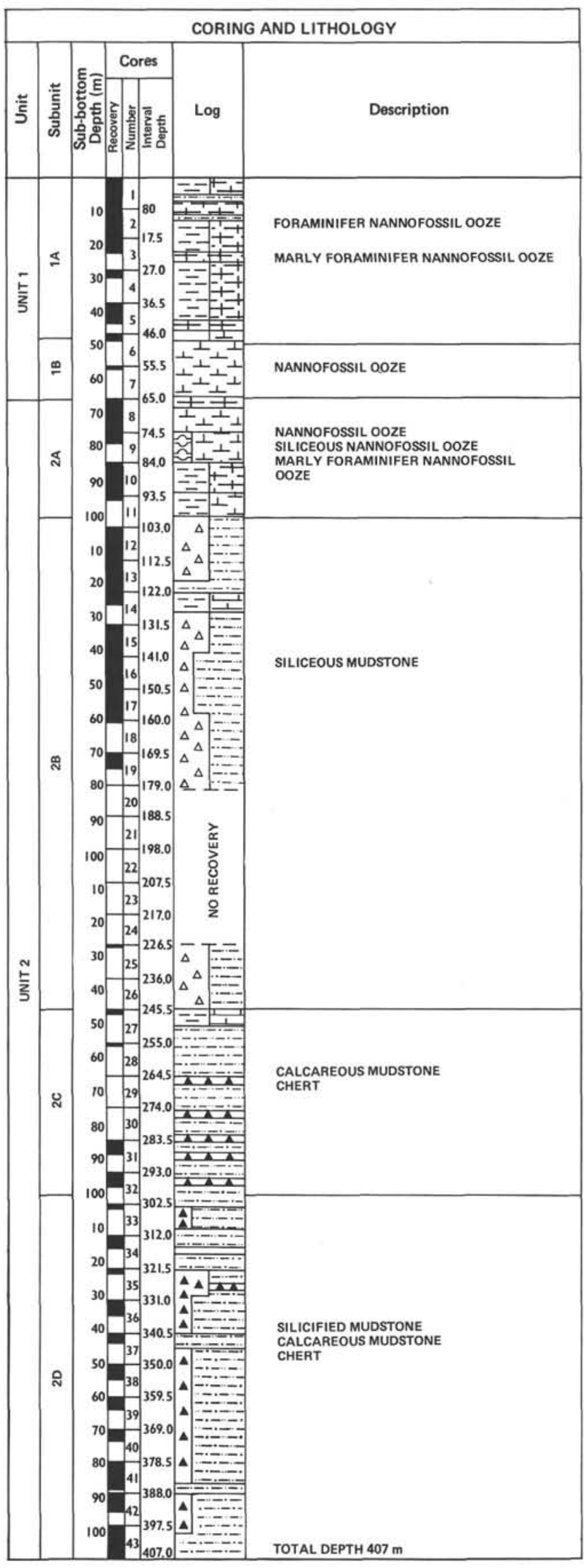

Figure 7. Lithologic summary - Site 405.
$(10-20 \%)$ and kaolinite $(10 \%)$. Pebbles interpreted to be of ice-rafted origin occur throughout the unit. These range in size from a few millimeters to $4 \mathrm{~cm}$ and include chert, sandstone, basalt, glauconitic mudstone, and various metamorphic lithologies. Some of the quartz and feldspar, which are particularly prominent in the marly ooze and calcareous muds near the top of the unit, may be ice-rafted in origin.

\section{Sub-Unit 1B}

Only two short cores were obtained from this sub-unit and both consist of bluish white nannofossil ooze of late Miocene to early Pliocene age. The sub-unit is distinguished from $1 \mathrm{~A}$ on the basis of bulk mineralogical differences which include a higher carbonate content (90-95\%), disappearance of quartz and feldspar, and reduction in content of chlorite and kaolinite in the clay mineral suite. Foraminifers are also much less conspicuous here. Pebbles occur in this sub-unit, but it is uncertain whether they are in situ.

\section{Unit 2}

The boundary between Units 1 and 2 corresponds to a 40-m.y. hiatus (late Miocene/early Eocene) across which a substantial change in mineralogical assemblage occurs. Calcium carbonate content undergoes an abrupt drop, illite disappears, and the clay mineral suite becomes dominated by smectite and a combination of amorphous silica and opal-CT. The uppermost part of the unit (Sub-unit 2A) is dominated by calcareous ooze, but contrasts in its color and significantly lower carbonate content to the oozes of lowermost Unit 1. Downward in the unit, calcium carbonate content declines steadily from about 30 per cent at 100 meters to about 5 per cent at 400 meters; the terrigenous fraction (smectite) and particularly opal-CT show a corresponding increase. Siliceous biogenic remains become prominent between 100 and 245 meters (Sub-unit 2B) and, below this, dark greenish gray calcareous mudstone prevails. Two additional sub-units are distinguished in the lower mudstone on the basis of dominance of bioturbation, more clay, and less pervasive silicification (Sub-unit 2C) and alteration of bioturbation and less laminated clay in addition to prominent silicification evidenced by abundant authigenic opal and chert (Sub-unit 2D). Smectite was the only clay mineral detected in the entire unit based on X-ray analysis.

\section{Sub-Unit 2A}

Foraminifer nannofossil ooze, nannofossil ooze, and siliceous nannofossil ooze of yellowish gray and grayish orange color make up this interval. The zone is generally uniform in appearance and lacks visible primary structures except for slight burrowing (including Zoophycos) and vertical streaks of pyrite.

An abrupt drop in the carbonate content takes place through this sub-unit from 70 per cent near the top (Core 8) to about 30 per cent near the bottom (Cores 10 and 11). A color change to olive-gray near the bottom of the section accompanies the carbonate decline and indicates a gradational change into the underlying sub-unit. Shore-based X-ray analyses show smectite and opal-CT as the only components in the clay-size fraction. 
TABLE 3

Lithologic Unit., Site 405

\begin{tabular}{|c|c|c|c|c|c|}
\hline Unit & Sub-Unit & Cores & $\begin{array}{l}\text { Sub-Bottom } \\
\text { Depth }(\mathrm{m})\end{array}$ & Lithology & Age \\
\hline \multirow[t]{3}{*}{1} & $1 \mathrm{~A}$ & $1-6$ & $0-47$ & $\begin{array}{l}\text { Marly foraminifer nannofossil ooze, } \\
\text { foraminifer nannofossil ooze }\end{array}$ & $\begin{array}{l}\text { Quaternary to early } \\
\text { Pliocene/late Miocene }\end{array}$ \\
\hline & & & & HIATUS & \\
\hline & $1 \mathrm{~B}$ & $6-7$ & $47-65$ & Nannofossil ooze & $\begin{array}{l}\text { Early Pliocene/late } \\
\text { Miocene }\end{array}$ \\
\hline & & & & HIATUS & \\
\hline \multirow[t]{4}{*}{2} & $2 \mathrm{~A}$ & $8-11$ & $65-100$ & $\begin{array}{l}\text { Foraminifer nannofossil ooze, } \\
\text { nannofossil ooze, siliceous nanno- } \\
\text { fossil ooze }\end{array}$ & Middle Eocene \\
\hline & $2 B$ & $12-26$ & $100-245$ & Siliceous calcareous mudstone & Middle and early Eocene \\
\hline & $2 \mathrm{C}$ & $27-32$ & $245-300$ & Calcareous mudstone & Early Eocene \\
\hline & $2 \mathrm{D}$ & $33-43$ & $300-407$ & Silicified mudstone, chert & Early Eocene \\
\hline
\end{tabular}

\section{Sub-Unit 2B}

Material recovered from this interval is dominantly olive-gray to dark greenish gray calcareous siliceous mudstone of early Eocene age. The unit is distinguished from those above and below primarily on the basis of the abundance of siliceous biogenous remains (chiefly radiolarians and sponge spicules), which average about 20 to 30 per cent of the sediment, and range as high as 40 per cent. Clay (20-30\%), nannofossils (15-60\%), and unspecified carbonate $(0-35 \%)$ comprise most of the remainder. Glauconite, quartz, and plant fragments occur in trace quantities through most of the section.

Cores recovered from the sub-unit generally were disturbed intensely so that conclusions concerning sedimentary structure are tenuous at best. The general impression, however, is that most of the section is highly bioturbated and only occasional evidence of lamination (Cores 14 and 19) was observed. Recovery was poor through the lower part of this sub-unit (174-246 m) due to blocking of the core barrel by 3 to $8 \mathrm{~cm}$ pebbles of various lithologies, including limestone, garnet gneiss, granite, siltstone, and gabbro. These lithologies are described in detail below. The matrix in which these pebbles are situated is probably siliceous mudstone.

\section{Sub-Unit 2C}

Calcareous mudstone of dark greenish gray color is the major lithology of this interval. Because recovery was poor (less than 10\%), except for Cores 31 and 32, conclusions concerning lithology are uncertain. The siliceous biogenous component disappears and detrital clay (smectite) becomes dominant. Both X-ray analysis and the downhole gamma-ray log indicate higher clay content in this sub-unit than in 2D below, but the clay content declines substantially toward the base as opaline silica increases. The sonic log run in this hole shows extremely variable sonic velocities reflecting variations in hardness from firm mud to hard rock, essentially chert, as noted in Cores 30,31 , and 32 . Thus, siliceous cement is spasmodic in occurrence through the sub-unit, and the presence of alternating hard and soft lithologies probably contributed to the poor recovery.
Bioturbation varies from slight to moderate in Cores 31 and 32 but, in contrast to Sub-unit $2 \mathrm{~B}$, the burrows here are markedly flattened parallel to bedding. Zoophycos and halo burrows are common. Plane lamination, in some cases with dips up to 10 degrees, and some indication of slump structure are evident in Cores 31 and 32 . The laminations and burrows are darker colored (olive-black to greenish black), less calcareous, and contain glauconite. Examination with the binocular microscope failed to reveal substantial differences in texture associated with the lamination.

\section{Sub-Unit 2D}

Dark greenish gray silicified mudstone with occasional chert layers composes the bulk of this sub-unit. In many respects the sediments in this sub-unit are similar to those in Sub-unit 2C, but are distinguished on the basis of a uniformly higher proportion of authigenic silica (opal-CT), correspondingly less clay, and by the common occurrence of laminations. The increased and more uniform silicification of this section compared to Sub-unit $2 \mathrm{C}$ is well exemplified by the downhole sonic velocity log, as well as by $\mathrm{X}$-ray mineralogy. Peak velocities and maximum silica contents are observed in the interval of Cores 35 to 37 $(320-350 \mathrm{~m})$ and below this the velocity decreases as the silica declines in deference to clay (smectite).

In terms of composition, the mudstones of this unit are rather uniform. Tabulation of 12 smear-slide determinations from the dominant lithology indicate the following averages for the common constitutents: undifferentiated clay $(60-70 \%)$, opal $(15-20 \%)$, unspecified $\mathrm{CaCO}_{3}(5-10 \%)$, nannofossils $(5-7 \%)$, foraminifers $(1-3 \%)$, quartz $(1-3 \%)$, and pyrite $(1 \%)$. Shore-based X-ray analysis detected only calcite, silica (amorphous and opal-CT), and smectite, which is significantly lower than in Sub-unit 2B. Sponge spicules were observed sporadically in the section. Carbonate bomb analysis shows a fairly steady 10 to 12 per cent $\mathrm{CaCO}_{3}$ through most of the section with a rise (up to $28 \%$ ) in the lowermost part.

Lenticular lamination, parallel lamination, and occasional cross-lamination on a millimeter to $1-\mathrm{cm}$ scale 
are common throughout the upper part of the section. These reflect slight variations in texture as well as composition. Beginning in Core 38, lamination becomes less common and one finds laminated intervals on the order of 20 to 40 $\mathrm{cm}$ thick, alternating with homogeneous or bioturbated intervals of comparable thickness. This pattern prevails to near the bottom of the hole where, in the lower 4 meters of Core 45, the sediment becomes homogeneous in appearance. Perhaps significantly in this interval, $\mathrm{CaCO}_{3}$ increases, nannofossils and foraminifers become more abundant, and opaline silica content decreases. It is also noteworthy that laminations and flattened burrows through this sub-unit show persistent dips which vary from about 15 degrees near the top (Core 34) to the order of 20 degrees near the base (Core 41). A 2-cm-thick bed of tuffaceous mudstone was observed in Core 43 , Section 6 , at the bottom of the hole.

\section{LITHOLOGY, SITE 406}

The 831.5-meter section penetrated at Site 406 includes sediments ranging in age from Quaternary to middle Eocene. The section is dominated by nannofossil ooze and chalk. Interbedded foraminifer nannofossil ooze and calcareous mud are found in the Quaternary. In the upper Eocene, Oligocene, and lower Miocene part of the section, intervals of siliceous chalk and diatomite become prominent, alternating with calcareous and/or nannofossil chalk and limestone which are characterized in parts by slump structures. The middle Eocene section near the bottom of the hole is notable for the marked dropoff in carbonate with concomitant increase in clay, chiefly smectite. Hiatuses in the section occur between the upper and middle Miocene, possibly within the lower Miocene, between the middle Oligocene and the upper Eocene, and between the upper Eocene and the middle Eocene.

The section (Figure 8 ) has been subdivided into five lithologic units and three sub-units (Table 4) which are discussed below from the top down.

\section{Unit 1}

Due to spot coring in the upper part of the hole, only two cores were taken from Unit 1 so that the boundary between Units 1 and 2 is arbitrarily placed at 110 meters sub-bottom. Sediments in this unit consist principally of olive-black calcareous mud, light olive-gray marly foraminifer nannofossil ooze, and very light gray foraminifer nannofossil ooze. These occur in rhythmic alternations ranging from 10 to $50 \mathrm{~cm}$ in thickness. The transition from the nannofossil ooze to the calcareous mud is gradational. Calcium carbonate content varies from 26 to 73 per cent and consists principally of nannofossils and foraminifers. Clay minerals (Latouche, this volume), including illite $(40 \%)$, smectite $(25 \%)$, chlorite $(18 \%)$, and kaolinite $(15 \%)$ constitute the bulk of the detrital fraction. Occasional ice-rafted pebbles occur throughout the unit.

\section{Unit 2}

Bluish white to light greenish gray nannofossil ooze and chalk comprise the bulk of Unit 2 . They contain occasional interbeds of foraminifer nannofossil chalk which are particularly evident in the sub-bottom depth interval 460 to 480 meters. In contrast to Unit 1 , sediments of Unit 2 are characterized by uniformly high calcium carbonate content (average 90\%) consisting principally of nannofossils but with a persistent small admixture of foraminifers. The small clay fraction (avg. 10\%) is dominated by smectite but a component of illite, kaolinite, and chlorite is found throughout the unit. In the upper part of the section (110-460 m), burrows of Zoophycos, often marked by pyrite concentrations, are common along with fine parallel and wavy laminations. Below 480 meters, a greater variety of burrows are found (Zoophycos, Teichnichus, halo, and composite) and sediments show a greater degree of bioturbation. In the intervening interval $(460-480 \mathrm{~m})$, wherein foraminifer nannofossil chalk is conspicuous, are contorted laminations, reflecting possible slumping, occasional graded layers, and millimeter scale plane laminations. In the same interval occurs a $10-\mathrm{cm}$ graded layer of volcanic ash containing glauconite. In the lower 10 to 20 meters of Unit 2, several changes in sediment characteristics are evident which mark a transition to Unit 3. These include: (1) predominance of greenish gray or yellowish gray color; (2) increase in siliceous biogenic components (chiefly radiolarians and sponge spicules); (3) notable drop in calcium carbonate; and (4) gradual disappearance of illite, chlorite, and kaolinite in the clay fraction (unspecified carbonate increases at the expense of nannofossils).

\section{Unit 3}

Unit 3 consists principally of greenish gray to pale greenish yellow diatomaceous chalk with interbeds of calcareous diatomite near the base. The abundance of biogenous silica (chiefly diatoms, 40-60\%), but with a small admixture of radiolarians (avg. 1\%) and sponge spicules (avg. 4\%), with paper-thin lamination which provides a striking fissility to the cores, serve to distinguish this unit from those above and below. Carbonate content generally ranges between 30 and 40 per cent in the unit and consists principally of unspecified carbonate and nannofossils with minor foraminifers. The clay mineral fraction, which constitutes 10 to 20 per cent of the total sediment, consists solely of smectite.

\section{Unit 4}

This 148-meter-thick unit has been divided into three sub-units based on changes in the lithology such as siliceous components content and the presence or absence of slump structure. Sub-unit 4A comprises dominantly calcareous chalk of late to middle Oligocene age; Sub-unit 4B is characterized by calcareous chalk and siliceous calcareous chalk of late Eocene age, interbedded at a centimetric to decimetric scale, and by the occurrence (starting in Section 36-2) of slump structures (Figure 9); Sub-unit 4C consists of limestone of late Eocene age. The unit is separated from Unit 3 on the basis of higher carbonate and lesser content of siliceous components as well as the occurrence of well-developed slump structures including beds as much as five meters thick.

\section{Sub-Unit $4 \mathrm{~A}$}

Sub-unit 4A consists dominantly of light greenish gray to pale green calcareous chalk with a few interbeds of yellowish green siliceous calcareous chalk and white 


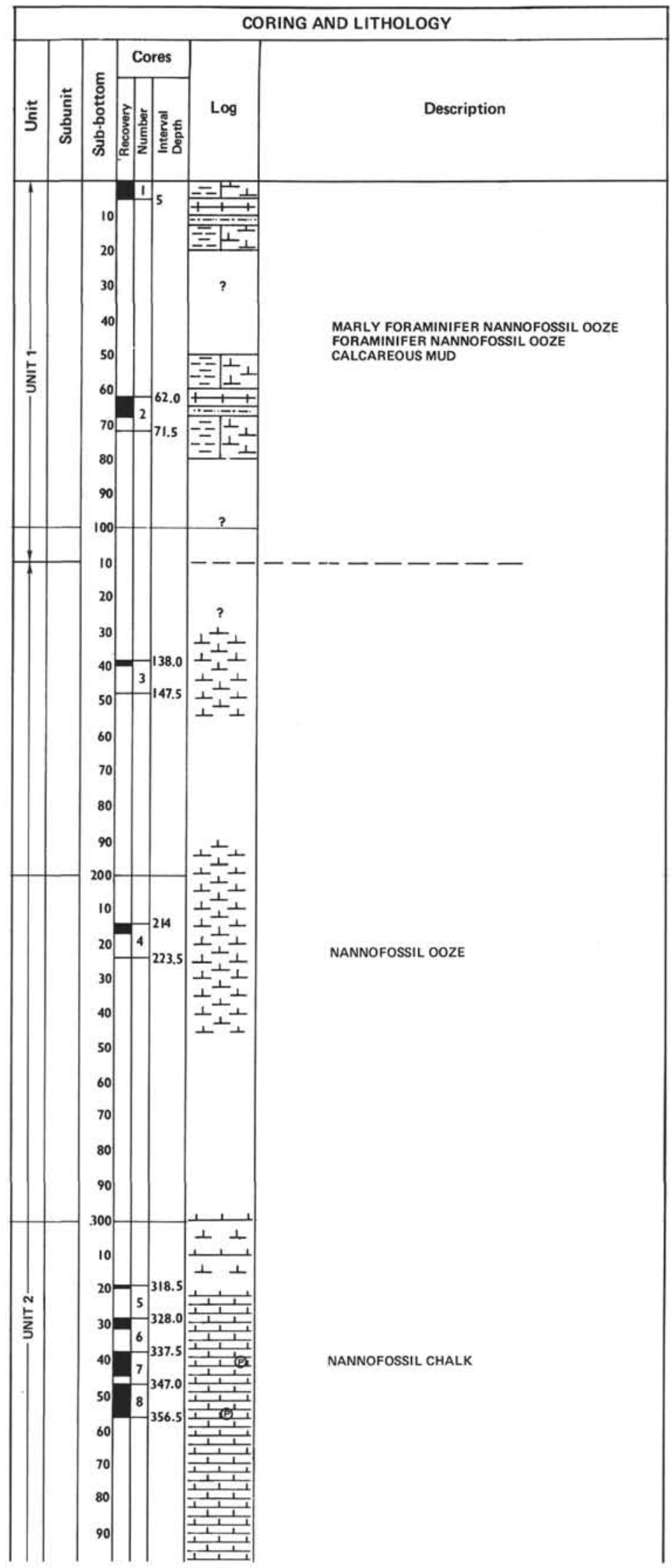

Figure 8. Lithologic summary - Site 406. 


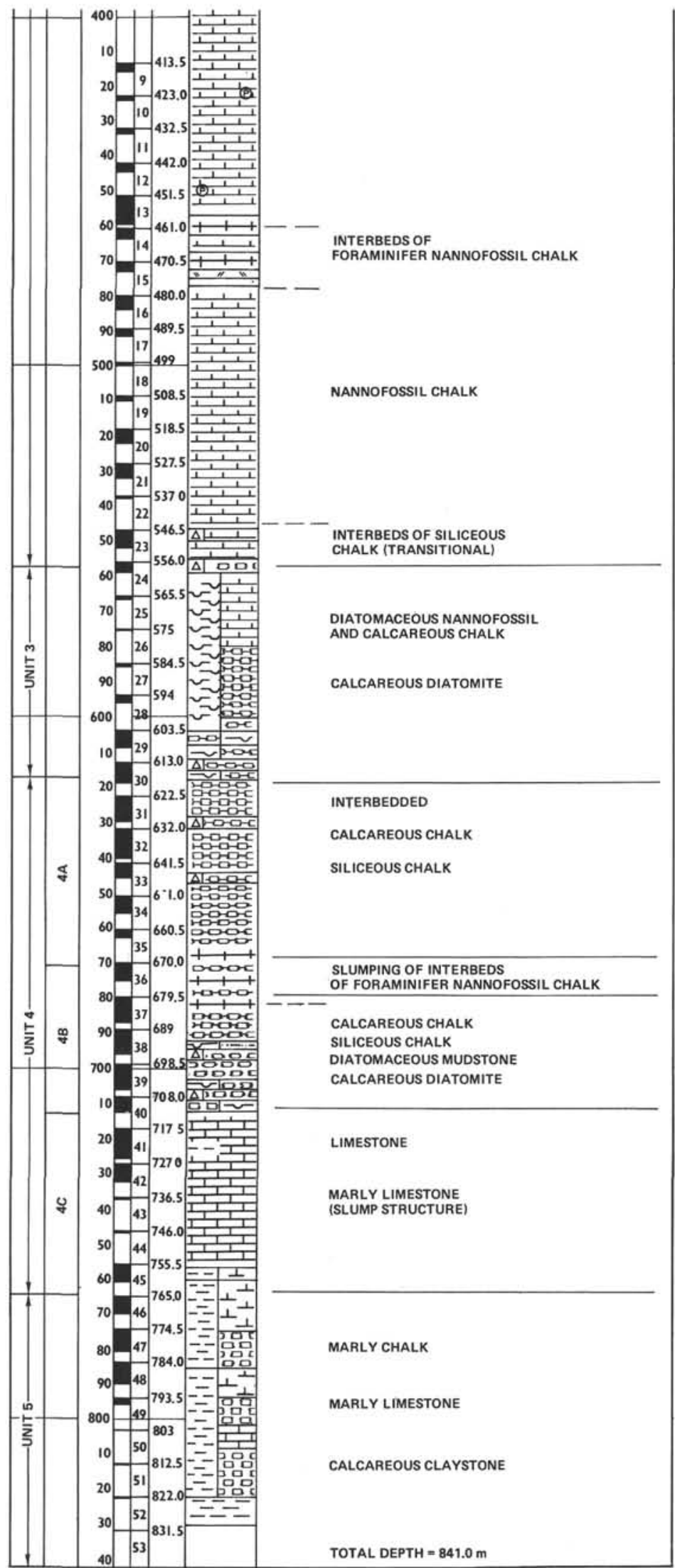

Figure 8. (Continued). 
TABLE 4

Lithologic Units, Site 406

\begin{tabular}{|c|c|c|c|c|c|}
\hline Unit & Sub-Unit & Cores & $\begin{array}{l}\text { Sub-Bottom } \\
\text { Depth }(m)\end{array}$ & Lithology & Age \\
\hline 1 & & $1-2$ & $0-110$ & $\begin{array}{l}\text { Marly foraminifer nannofossil ooze, } \\
\text { foraminifer nannofossil ooze, cal- } \\
\text { careous mud }\end{array}$ & Pleistocene \\
\hline \multicolumn{6}{|c|}{ HIATUS } \\
\hline 2 & & $3-24(1)$ & $110-557.5$ & $\begin{array}{l}\text { Nannofossil ooze, nannofossil chalk, } \\
\text { siliceous nannofossil chalk }\end{array}$ & $\begin{array}{l}\text { Pliocene to }{ }^{a} \\
\text { middle Miocene }\end{array}$ \\
\hline 3 & & $24(2)-30(3)$ & $557.5-617.5$ & $\begin{array}{l}\text { Diatomaceous nannofossil chalk, } \\
\text { calcareous chalk, calcareous } \\
\text { diatomite }\end{array}$ & $\begin{array}{l}\text { Early Miocene } \\
\text { to late Oligocene }\end{array}$ \\
\hline 4 & $4 \mathrm{~A}$ & $30(4)-36(1)$ & $617.5-671.5$ & Calcareous chalk, siliceous chalk & $\begin{array}{l}\text { Late to middle } \\
\text { Oligocene }\end{array}$ \\
\hline \multicolumn{6}{|c|}{ HIATUS } \\
\hline & $4 \mathrm{~B}$ & $36(2)-40(2)$ & $671.5-711$ & $\begin{array}{l}\text { Calcareous chalk, siliceous chalk, } \\
\text { diatomaceous mudstone, calcareous } \\
\text { diatomite }\end{array}$ & Late Eocene \\
\hline & $4 \mathrm{C}$ & $40(3)-45$ & $711-765$ & Limestone, marly limestone & Late Eocene \\
\hline \multicolumn{6}{|c|}{ HIATUS } \\
\hline 5 & & $46-52$ & $750-831.5$ & $\begin{array}{l}\text { Marly calcareous chalk, marly lime- } \\
\text { stone, calcareous claystone }\end{array}$ & Middle Eocene \\
\hline
\end{tabular}

${ }^{\mathrm{a}} \mathrm{A}$ hiatus is also present within Unit 2.

foraminifer nannofossil chalk. The carbonate content (avg. $78 \%$ ) consists dominantly of unspecified carbonate $(50 \%)$, abundant nannofossils (20\%), and foraminifers (up to $4 \%$ ). Biogenic siliceous components constitute only 8 per cent (diatoms, 3\%; sponge spicules, 4\%; radiolarians, $1 \%$ ), whereas the content of clay $(18 \%)$ shows qualitatively and quantitatively few changes relative to Unit 3 . Traces of glauconite are observed particularly in Cores 33 and 34 . Pebbles including cherts are present in Core 35 .

Sedimentary structures include interbedding of laminated diatomaceous calcareous chalk in bioturbated calcareous chalk at a scale of a few centimeters, and occasional foraminifer-rich "grit" layers a few millimeters thick. The degree of this interbedding decreases downward so that calcareous chalk becomes the dominant lithology and occurrences of siliceous sediments are reduced to occasional darker "wavy" laminae such as in the core catcher of Core 35. Oblique fractures characterized by slickensides occur in Core 34, Section 2.

\section{Sub-Unit 4B}

Light greenish gray calcareous chalk and siliceous calcareous chalk interbedded at a centimetric to decimetric scale compose most of Sub-unit 4B. It is distinguished from Sub-unit $4 \mathrm{~A}$ on the basis of the occurrence of slumped beds and variations in the lithology opposed to the more homogeneous character of the previous section.

The average mineralogic composition includes 12 per cent of biogenic siliceous component (diatoms, $6 \%$; sponge spicules, $5 \%$; radiolarians, $1 \%$ ) as opposed to 8 per cent in Sub-unit 4A where the carbonate content averages 71 per cent. Clay mineral content average 18 per cent and comprises mostly smectite.
The sedimentary structures are particularly varied in Sub-unit $4 \mathrm{~B}$ and constitute a clear criterion for distinction from Sub-unit 4A. The most important among these are slump structures that affect the foraminifer calcareous chalk and calcareous chalk. Slumps which are found in Sections 37-1 and 2 and 37-2 to 4 are small scale, averaging less than 1 meter in thickness. These levels consist mainly of calcareous chalk exhibiting a complex interbedding of colors, contorted bedding, and inclined contacts. They are separated by intervals of laminated and, in places, upward-fining sequences (Core $37-2 ; 20-50 \mathrm{~cm}$ ) of foraminifer nannofossil chalk or calcareous chalk.

Small-scale sedimentary structures are also present and include (1) microfaulting and micro-slumps in the laminated sediment (Sample 37-3, 70-100 cm); (2) "varve like", laminations produced by the alternation of calcareous and siliceous-rich sediment; and (3) small lenses of coarser calcareous chalk interbedded in siliceous calcareous chalk. These contain (as in Section 37-21) abundant foraminifer fragments and glauconite.

\section{Sub-Unit 4C}

Limestone, nannofossil limestone, and a few foraminifer nannofossil limestone layers make up Sub-unit 4C. Compared to Sub-unit 4B, the biogenic siliceous component is rare. The average mineralogical composition is characterized by the abundance of carbonate (avg. 80\%) consisting mostly of unspecified debris (70\%) and nannofossils (10\%); minor components include foraminifers $(1 \%)$, dolomite $(1 \%)$, and sponge spicules.

From the point of view of the sedimentary structures, the most striking features are the slump beds that occur in Core 41, Sections 5 and 6; Cores 42 and 45, Sections 1 to 3. 


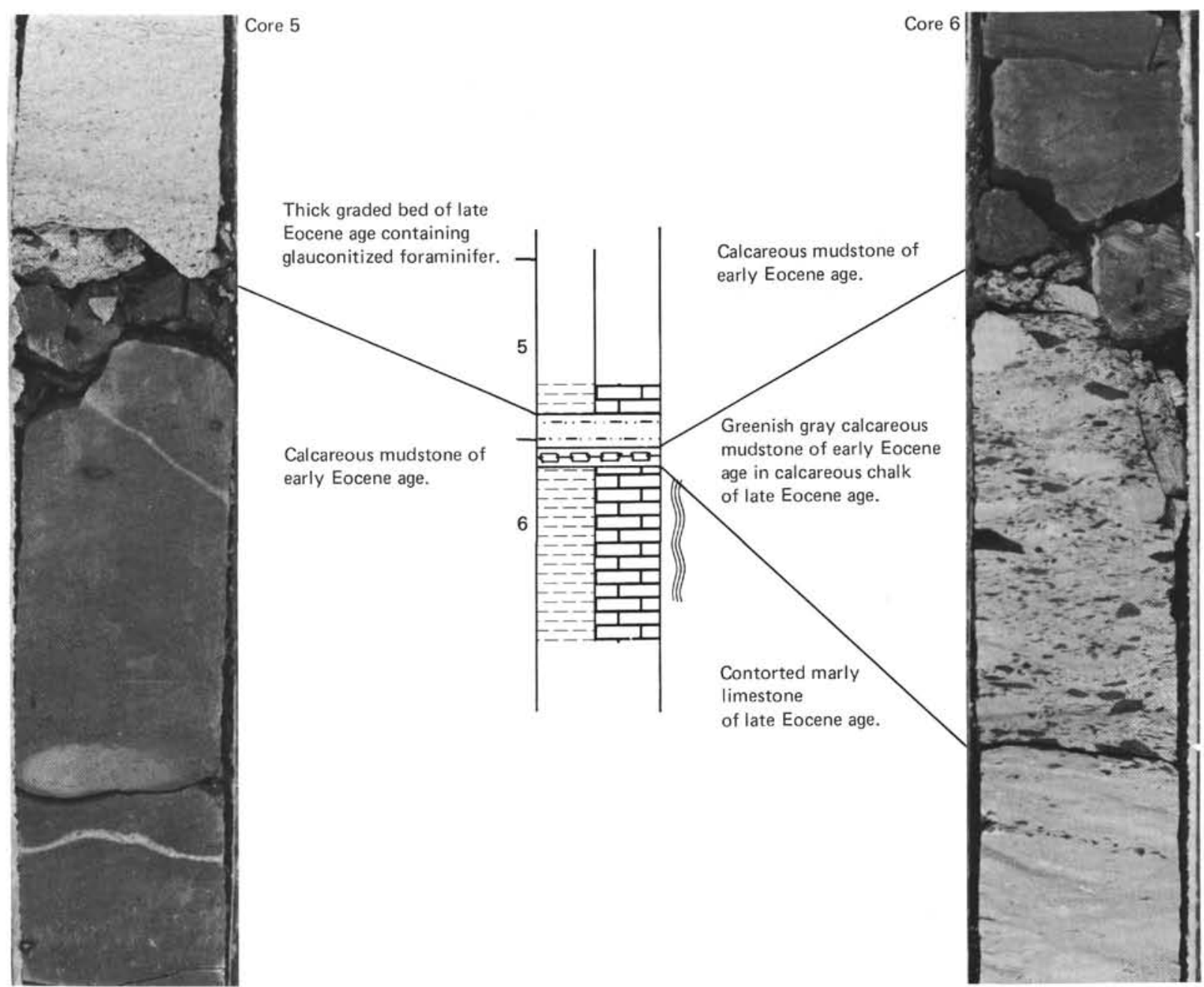

Figure 9. (a) Sketch of upper Eocene slump observed in Core 41, Sections 5-6. (b) Photograph of upper Eocene slump (Core 41, Sections 5-6).

The top of the slump in Sections 41-5 to 6 is characterized by complex interbedded lithologies. These are summarized schematically in Figure 9a and are described below from bottom to top. Section 6 exhibits light gray marly limestone of late Eocene age that is characterized by frequent slickensided fractures and contorted bedding. This is overlain (Sample 41-6, 10-23 cm) by a conglomerate containing gravel-sized fragments of greenish gray calcareous lower Eocene mudstone, in a matrix of upper Eocene calcareous chalk. On top of this conglomerate (Samples 41-6, 0-10 cm and 41-5, 130-150 cm) occurs a bed, $30 \mathrm{~cm}$ thick, of dark greenish gray calcareous mudstone of early Eocene age. This section ends with a 20 $\mathrm{cm}$-thick graded bed of late Eocene age that includes glauconitized foraminifers. The base of these slumped beds is not clearly distinguished by structure. In Section 3 of Core 45 at about $55 \mathrm{~cm}$, the lowest occurrence of the brownish gray streaks that characterize the slumped materials occur. At 115 centimeters in the same section truncation of a Zoophycos burrow is present; this level exhibits also some soft gravels.

\section{Unit 5}

Unit 5 consists of brownish gray to gray marly calcareous chalk and marly limestone. The top of the unit is characterized by a marked color change from light gray to grayish brown; the base of the unit in Section 52-1 consists of a thin interval $(12 \mathrm{~cm})$ of calcareous mudstone. The carbonate content averages 32 per cent and consists mainly in nannofossils (19\%) and unspecified carbonate (13\%). Clay mineral content reaches up to 70 per cent and consists almost entirely of smectite; sponge spicules and glauconite appear as minor components and the less than $2 \mu \mathrm{m}$ fraction comprises also opal (0-18\%).

Sedimentary structures are rare in these marly limestone and include, particularly in Section 48-2, lenses of brownish black limestone, green-black laminae, traces of bioturbation, and, in Core 49 a pinkish gray pebble of dolostone 
which is hollow, suggesting that it was indurated sometime before it was buried.

\section{BIOSTRATIGRAPHY}

\section{Site 405 (Figure 10)}

Pleistocene to upper Miocene foraminifer and nannofossil oozes and middle to lower Eocene siliceous oozes, chalks, and mudstones were recovered through continuous coring down to 407 meters depth. Although of low species diversity, calcareous micro- and nannofossils are abundant and well-preserved in the incomplete Neogene section, particularly in the Pleistocene. The planktonic foraminifers and nannofossils indicate cold water. The benthic foraminifers and ostracodes are typical of a lower bathyal environment with some species displaced from the upper slope and shelf. Dinoflagellates were found only in the Quaternary sediments. Almost the total Pliocene section is missing.

The upper Miocene of Sample 7, CC (N.17-16, NN 11) is underlain directly by a thick sequence of middle and lower Eocene sediments; the hiatus represents an interval of about 43 m.y. The Eocene planktonic foraminifers are of small size, often poorly preserved, and of low species diversity. Nannofossil assemblages are markedly variable (disappearance and reappearance of species), which may be due to changing ecologic factors. The benthic foraminifers and ostracodes indicate deposition of the middle and lower Eocene sediments on the continental slope. Occasionally a high number of upper slope/shelf edge species are present. The marginal dinocysts (Costa and Downie, this volume) and nannofossil assemblages are, in general, rich and diversified. Radiolarians, diatoms, and sponge spicules are often abundant, especially from Core 12 to Core 20 .

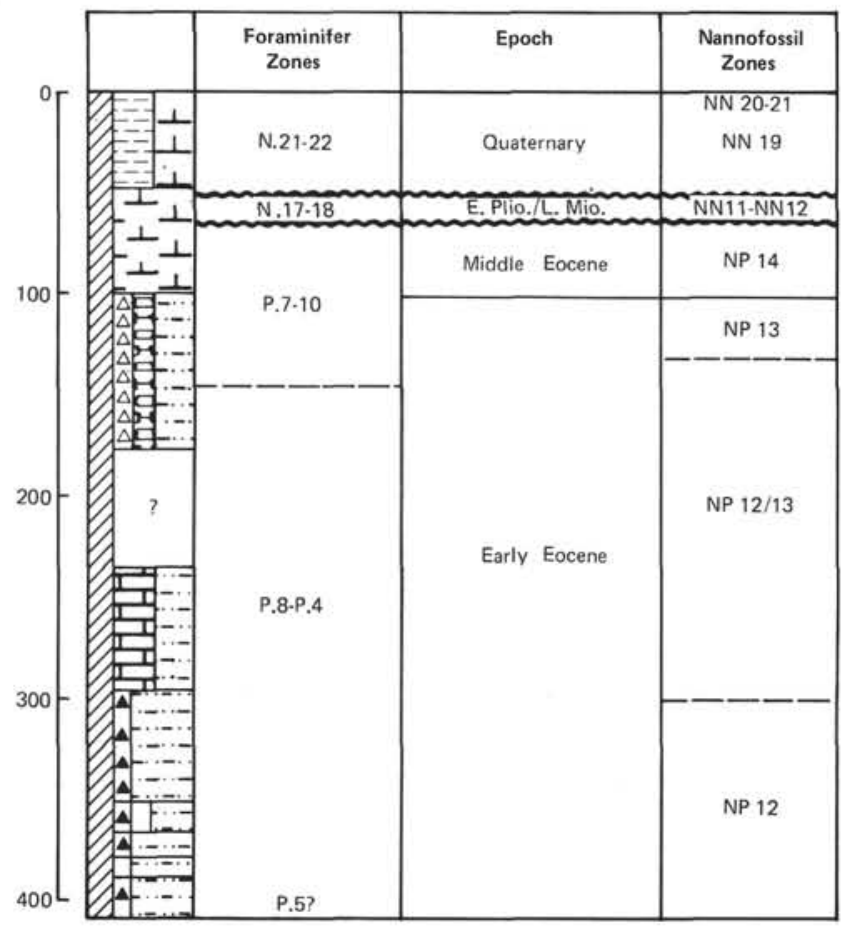

Figure 10. Biostratigraphic summary - Site 405.

\section{Foraminifers}

Pleistocene sediments occur in Cores 1 to 5 . The foraminiferal assemblages of those cores are abundant and well preserved, with planktonic species comprising about 99 per cent of the total foraminiferal fauna. Globorotalia inflata, Globigerina bulloides, and Globigerina pachyderma are the most abundant species, indicating relatively cold water. Other planktonic species are few to common: Orbulina universa (common), Globorotalia truncatulinoides (few), Globorotalia crassaformis (common), Globorotalia scitula (few to common), and Hastigerina aequilateralis (few). Benthic foraminifers (Murray, this volume) indicate a lower bathyal environment, but from time to time contaminants from shelf or upper slope are present, i.e., in Sample 3, CC Cibicides cf. C. lobatulus and fragments of bryozoans probably were derived from the shelf. The oldest Pleistocene sediments were recovered from Sample 5, CC where rare Globorotalia truncatulinoides occurs along with a few specimens of Globigerina cf. $G$. atlantica.

Lowermost Pliocene/uppermost Miocene sediments (Zone N.18) are present in Core 6, wherein a few specimens of Globorotalia margaritae, G. acostaensis, G. miocenica, $G$. scitula, and $G$. atlantica occur. Benthic foraminifers are somewhat more abundant than above (about $4 \%$ of the total foraminiferal fauna), and are a mixture of lower bathyal and upper-slope forms such as Bulimina and Bolivina.

Sample 7, CC contains an assemblage from the upper Miocene (Zones N.17-N.16) with G. pseudomiocenica and G. acostaensis. Benthic forms are similar to those in Core 6.

Sample 8, CC contains middle to lower Eocene sediments, indicating an important hiatus between Cores 7 and 8 . From this core to the bottom of the hole, the planktonic foraminiferal assemblage shows three constant characteristics: small size, low diversity, and intergradational species.

Small size of the species and, in places, poor preservation render identification difficult; in the cases of Cores 29 and 33 identification is impossible. Generally, the assemblages contain two or three species such as Globigerina spp. and Globorotalia spp. (Acarinina) which are represented by relatively large numbers of specimens. In such an assemblage the globigerinids and globorotalids are not typical specimens, i.e., all globorotalids are part of a bioseries that encompasses $G$. bullbrooki (Acarinina densa), $G$. pseudotopilensis, $G$. esnaensis, and $G$. primitiva, without exhibiting the definitive characteristics that would allow their classification into one of the above-named species. For instance, in some samples specimens are similar to $G$. bullbrooki or $G$. primitiva. In some cases the globorotalids are absent (Samples 18, CC and 26, CC), but reappear somewhat lower in the section. Possibly the atypical morphology, along with their disappearance and reappearance, is due mainly to variations of ecologic factors, perhaps temperature. The same phenomenon applies to globigerinids. All specimens can be identified with Globigerina boweri, G. triangularis, or $G$. linapertura, but for the most part the identifications are not positive. It appears in many cases that the specimens correspond to the $G$. triangularis- $G$. linapertura group and less to $G$. boweri. 
As a result of such characteristics, it is practically impossible to assign a precise stratigraphical range to these samples, and the sediments can only be roughly assigned as lower Eocene to upper Paleocene (generally Zones P.9 to P.4). The lowest sample (Sample 43, CC) contains an assemblage that is somewhat more diversified; it contains Globorotalia imitata, $G$. perclara, and one specimen of Zeauvigerina aegyptiaca.

From a paleoenvironmental point of view, the rare and moderately well preserved benthic foraminifers are a mixture of bathyal and upper-slope to shelf specimens, and the entire lower Eocene sequence was deposited probably on the continental slope, with frequent shelf contaminants.

\section{Nannofossils}

The Pleistocene sediments $(0-46.0 \mathrm{~m})$ are rich in wellpreserved nannofossils, but, in some layers, a low content may result from dilution by terrigenous material. Reworked species from the Cretaceous and Eocene are present in almost all samples. The thickness of the upper part of the Quaternary is reduced; the Emiliania huxleyi Zone (NN 21) is determined in Samples 1-1, 47-48 cm and 1-2, 75-76 cm; the Gephyrocapsa oceanica Zone (NN 20) includes the section from Samples 1-3, 27-28 cm to 2-3, 103-104 cm; Samples 2-4, 76-77 cm to 5, CC belong to the Pseudoemiliania lacunosa Zone (NN 19). Coccolithus pelagicus, Cyclococcolithus leptoporus, Pseudoemiliania lacunosa, the small variety of Gephyrocapsa oceanica, Discolithina japonica, and Pontosphaera pacifica are the most frequent species. A hiatus, which represents an interval of about $3.2 \mathrm{~m}$.y. lies between Core 5 and Core 6 . Core 6 probably belongs to the lower Pliocene (Ceratolithus tricorniculatus Zone, NN 12); in it a few specimens of $C$. tricorniculatus occur but Discoaster quinqueramus is absent. The slightly etched nannofossils are abundant. Reworked Eocene species occur in Sample 6-1, 73-74 cm.

The Discoaster quinqueramus Zone (NN 11) of the upper Miocene is recognized in Samples 7-1, 16-17 cm and 7-1, $45-46 \mathrm{~cm}$ wherein a few specimens of $C$. tricorniculatus and Discoaster quinqueramus are present. The nannofossils are abundant and well preserved to slightly etched. Coccolithus pelagicus, Cyclococcolithus macintyrei, and Reticulofenestra pseudoumbilica are frequent. Discoasters and Sphenolithus abies are scarce, indicating low water temperatures.

The upper Miocene (Zone NN 11) is underlain by the middle Eocene Discoaster sublodoensis Zone (NP 14) which is present from Core 8 to Sample $11-1,22-23 \mathrm{~cm}$ $(65.0-95.0 \mathrm{~m})$. Eocene sediments are rich in partially broken nannofossils that are well preserved from Core 9 downwards; occurring with them are siliceous microfossils. The nannoplankton assemblage of the Discoaster sublodoensis Zone is highly diversified; Chiasmolithus solitus and discoasters are abundant. Rhabdosphaera inflata and Chiphragmolithus cristatus were found in several samples, the former appears to be restricted to this zone.

The Discoaster lodoensis Zone (NP 13) encompasses from Samples 11, CC to 31-3, 105-106 cm (103.0-288.0 $\mathrm{m})$, wherein the nannofossils are abundant but partially broken. D. lodoensis is rare in almost all samples. A few specimens of Marthasterites tribrachiatus are present in
Core 5, Sections 1 and 2 and of Imperiaster obscurus from Core 25 downwards; $I$. obscurus becomes more frequent in Sample 31, CC. Both species were attributed until now, only from the $D$. binodosus Zone (NP 11) and $M$. tribrachiatus Zone (NP 12). The fact that the two species are found in several samples of the D. lodoensis Zone (NP 13) may be explained either by a longer range than previously believed or by the absence of these species in all other samples due to local ecologic conditions; the latter interpretation is less convincing. Chiasmolithus solitus, Coccolithus pelagicus, Transversopontis pulcher, Zygolithus dubius, and Reticulofenestra umbilica are the most abundant species.

Diatoms, sponge spicules, and radiolarians are more or less abundant within this section. Siliceous microfossils are absent from Core 26 downwards. $M$. tribrachiatus together with $D$. lodoensis and Imperiaster obscurus become more frequent in the interval from Samples $32-1,99$ to $100 \mathrm{~cm}$ to 43 , CC, which belongs to the M. tribrachiatus Zone (NP 12). There the nannofossils are less abundant and are badly preserved. $D$. lodoensis is present only sporadically in the lower part of this zone and a few specimens of Rhabdolithus solus were found in the lower part of the zone.

\section{Dinoflagellates ${ }^{2}$}

Section 43-6 yields lower Eocene assemblage of Zone II (Costa and Müller, 1978), similar to that from Site 404, Core 16-1, equivalent in age to the upper London Clay. Its composition indicates shelf environment.

Section 43-1 to Core 19 yield Zone III assemblages, with Kisselevia spp., equivalent to those from the lowermost Bracklesham Beds of England. The assemblage of Section 43-1 correlates closely with Core 12 of Site 404; both have high proportions of Hemicystodinium zoharyi, apparently indicating warm water. Section 43-1 has more dinocysts and fewer acritarchs than its equivalent at Site 404 , and may be considered to be a deeper, more distal site. Section 41-3 correlates with Section 10-1 from Site 404; both assemblages are dominated by Micryhstridium, Areoligera, and Spiniferites.

The younger cores of Zone III at Site 405 may have no equivalents at Site 404 . The dinocyst assemblages are rich and diversified. Thalassiphora and Impletosphaeridium dominate in Section 37-1. Spiniferites and Cordosphaeridium are prevalent in Section 31-1. In Section 19-1, Spiniferites and Systematophora are dominant.

Cores 16 to 14 yield diversified assemblages of Zone IVa, including Phthanoperidinium tritonium; these are equivalent to the lower to middle parts of the Bracklesham Beds of England, and to the Eozän 4 of north Germany. Cores 16 and 15 are dominated by Micrhystridium and Homotryblium tenuispinosum, whereas, in Core 14, Thalassiphora is dominant. These samples represent an oceanic environment.

Mid-Eocene assemblages appear in Core 13 and extend to Core 10 (Zone IVb). These are equivalent in age to the mid to upper Bracklesham Beds. They are variable assemblages.

${ }^{2}$ Contribution by Lucy I. Costa and Charles Downie, Geology Department, The University, Mappin Shelt, Sheffield S13JD, United Kingdom. 
Section 13-4 is dominated by Systematophora and Spiniferites; Achomosphaera membraniphora reaches its peak in this interval. Section $12-5$ is dominated by Micrhystriudium, Spiniferites, and Phthanoperidinium. Section $11-1$ is dominated by Impletosphaeridium. Section 10-6 is barren, but Section 10-1 yields an assemblage dominated by Micrhystridium and Hemicystodinium zoharyi.

Above Core 10, no dinocysts are recorded until Quaternary beds are reached. Cores 9 and 7 yield only carbonized tracheids. Core 3 yields a little diversified Pleistocene dinocyst assemblage as well as many reworked Cretaceous and Eocene forms. Reworking in this hole is confined to the Pleistocene.

The Thermal Alteration Index is low throughout (1-1.5); the highly carbonized material in the Pliocene sediments is attributed to oxidation (during transport?).

\section{Site 406 (Figure 11)}

Discontinuous coring down to 413.5 meters recovered foraminifer and nannofossil oozes of Pleistocene, Pliocene, and late Miocene age, deposited in a lower bathyal environment as indicated by benthic foraminifers and ostracodes. Continuous coring down to 831.5 meters recovered foraminifer and nannofossil chalks, diatomites, calcareous chalks, marly limestones, and claystones of Miocene, late to middle Oligocene, and late to middle Eocene age.

Preservation of the calcareous micro- and nannofossils, good to excellent at the top, deteriorates progressively downhole. Diagenetic processes (cementation, recrystallization, calcite overgrowth, and compaction) rather than carbonate dissolution have caused the poorly preserved state of the fossils.

Two small unconformities within the Miocene sequence can be assumed. One hiatus seems to be present between Core 15 and Core 16 (between the upper and middle Miocene), and represents a maximum interval of 4 m.y. The other hiatus is assumed within the lower Miocene, but because of the poor micro- and nannofossil assemblages it is difficult to prove its existence. Middle to upper Oligocene sediments are underlain by an upper Eocene section. A hiatus representing an interval of about $8 \mathrm{~m} . \mathrm{y}$. lies within Core 36. Upper Eocene sediments (from about 670 to 755.0 $\mathrm{m})$ are distinguished by the presence of slump structures; reworked species from the lower middle Eocene are abundant in several samples. Benthic foraminifers and ostracodes (Murray, Ducasse, and Peypouquet, this volume) of the upper and middle Eocene sediments are typical of a middle to lower bathyal environment with some contaminants from the upper-slope/shelf environment. The upper Eocene section is underlain by middle Eocene sediments rich in nannofossils, whereas planktonic foraminifers are rare or absent. A hiatus of about $6.5 \mathrm{~m}$.y. exists between these two stratigraphic intervals. Rich and well-diversified dinoflagellate assemblages are present in the middle Eocene, whereas they are poor in upper Eocene sediments (Costa and Downie, this volume).

\section{Foraminifers}

Core 1 ( $5 \mathrm{~m}$ below sea floor) and Core $2(71.5 \mathrm{~m}$ below sea floor) contain Pleistocene sediments. Foraminifers are abundant and well preserved. Planktonic foraminifers are

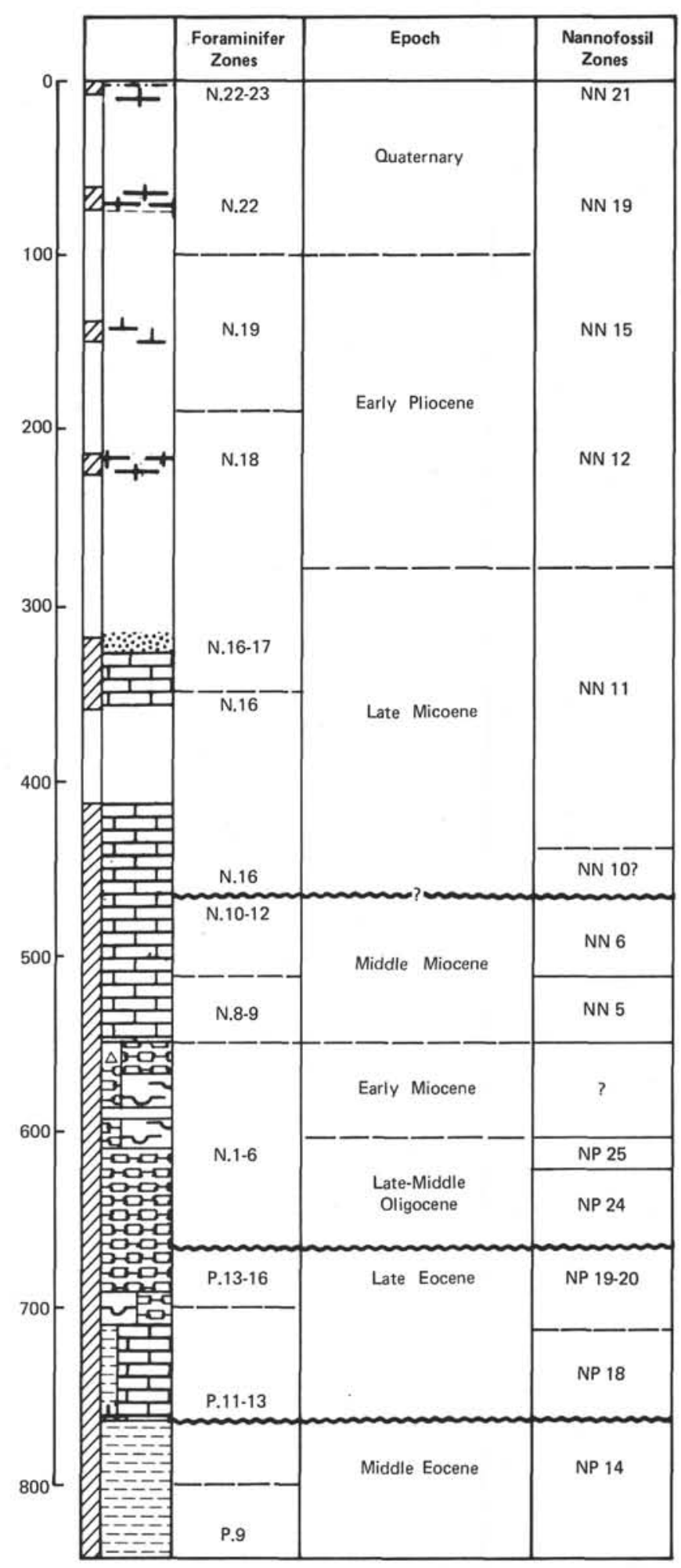

Figure 11. Biostratigraphic summary - Site 406.

dominant (greater than $98 \%$ in Core 2), Globorotalia inflata and Globigerina bulloides being most abundant. Globorotalia scitula and Globigerina pachyderma are common in Sample 1, CC, whereas Globorotalia crassaformis is common in Sample 2, CC. In these two cores $G$. truncatulinoides is present but rare. Benthic foraminifers are all from deep water (lower bathyal to 
abyssal) and are dominated by Uvigerinids in Core 2 (Uvigerina hollicki and $U$. auberiana).

A Pliocene foraminiferal assemblage is present in Core 3 (147 $\mathrm{m}$ below sea floor). $G$. bulloides is still abundant, $G$. atlantica and Globorotalia scitula are common; $G$. puncticulata is rare. The benthic assemblages still indicate deep water. Lowermost Pliocene was recovered in Sample 4 , CC where a few specimens of $G$. margaritae (Zone N.18) occur along with $G$. acostaensis and Globigerina bulloides. Benthic foraminifers continue to be rare and indicate bathyal to abyssal depths.

Upper Miocene sediments were encountered from Core 6 ( $328 \mathrm{~m}$ below sea floor) to Core 19 ( $518 \mathrm{~m}$ below sea floor). Cores 5 to 8 containing Globorotalia pleisiotumida and $G$. pseudomiocenica indicate the uppermost Miocene (Zone N.17) where, in Cores 9 to 19 , the presence of $G$. merotumida and the abundance of Globigerina praebulloides indicate the presence of Zone N.16. Benthic foraminifers indicate the same deep-water environmental characteristics. In the entire upper Miocene sequence the foraminiferal assemblages comprise abundant and well to moderately preserved specimens, but in Cores 14 and 19 foraminifers are rare and poorly preserved.

Cores 20,21, and 22 contain the middle Miocene forms such as Globigerinoides sicanus and Praeorbulina transitoria; rare Orbulina suturalis in Sample 22, CC indicates that these three cores are from the base of Zone N.9. Benthic foraminifers, which represent about 1 per cent the total foraminiferal fauna, are from a lower bathyal environment.

Foraminifers are rare and poorly preserved in Core 23 but radiolarians, sponge spicules, and diatoms are common to abundant. Globorotalia kuglier has been tentatively identified among the rare and broken specimens of planktonic foraminifers which, if correct, points to a lower Miocene section. Diatoms are even more abundant in Cores 24 to 28. In some cases (Cores 24 and 25) there are essentially only large diatom fragments, which are present as aggregates and numerous small broken flakes. The rare planktonic foraminifers are principally Globigerinita dissimilis, Globigerina tripartita, and Globoquadrina praedehiscens, indicating a lower Miocene to upper Oligocene interval. The same type of foraminiferal assemblage persists to Core 34 , but diatoms decrease in abundance.

The presence of Globigerina prasaepis in Sample 35, CC along with common Globigerinita dissimilis indicates upper Oligocene; Globigerina prasaepis persists into Sample 36, $\mathrm{CC}$, along with Globoquadrina praedehiscens. In this entire lower Miocene and upper Oligocene sequence benthic foraminifers are rare and continue to indicate lower bathyal to abyssal water (Murray, this volume).

Core 37 contains a rich, poorly preserved foraminiferal assemblage, but the presence of Globigerapsis index along with rare Chilogumbelinas and Globigerina yeyuaensis indicates middle to upper Eocene sediments. Preservation is poor in Sample 38, CC, and Sample 39, CC is barren of foraminifers, whereas radiolarians, diatoms, and sponge spicules are common. Cores 41 to 44 still contain Globigerapsis index along with specimens tentatively identified as Globigerapsis kugleri, the final chambers of which appear to be too small. The presence of Globigerinita unicava primitiva associated with $G$. kugleri indicates Zones P.13 to P.16. If the questionable specimens indeed are $G$. kugleri, the zone could be restricted to P.13.

Sample 45, CC and Core 46, Sections 1 to 2 are reddish brown clayey mudstones, washed residue from which contains rare, small, poorly preserved foraminifers, mainly Hastigerina micra and Globigerina cf. G. boweri. In Sample 45, CC and the top of Core 46, Section 1, there are burrows full of gray sediments which contain a relatively abundant, moderately preserved foraminiferal assemblage dominated by Globigerapsis kugleri. In Sample 47, CC three specimens of $G$. kugleri along with Hastigerina micra were observed. This places Core 46 , Section 1 and Core 47 in the middle Eocene Zones P.11 to P.13 which is not in agreement with the nannoplankton Zone NP 14, determined for the same interval. It appears that in the gray sediments and in Sample 47, CC G. kugleri may be allochthonous. Benthic foraminifers are rare in this entire upper to middle Eocene section, except in Sample 46, CC (60\%) and Sample 47 , CC $(9 \%)$ where there is a mixture of lower bathyal and upper-slope species; the other cores contain only deep water species. The same type of assemblage was found in Sample 49, CC as in the lower Eocene from Hole 405. It is dominated by forms transitional between Globorotalia (Acarinina) primitiva and G. (Acarinina) bullbrooki (with Globorotalia soldadoensis and $G$. pseudotopilensis). The presence of a single specimen of Globorotalia caucasica corroborates the assignment to lower Eocene. Core 50 is similar, but Core 51 is practically barren of foraminifers, containing only a few agglutinated benthic specimens. Sample 52, CC contains a lower Eocene assemblage dominated by Hastigerina micra and Globigerina cf. $G$. boweri with a few specimens of Globorotalia perclara. The benthic forms of the lower Eocene sediments continue to be represented by bathyal species with some shallower contaminants such as Lenticulina, Nonion, and Bolivina.

\section{Nannofossils}

Core $1(0-5.0 \mathrm{~m})$ contains the Quaternary Emiliania huxleyi Zone (NN 21). Among the abundant and well-preserved nannofossils, Coccolithus pelagicus, Emiliania huxleyi, and the small variety of Gephyrocapsa oceanica are the most frequent species. Reworked Cretaceous species are rare. The Pseudoemiliania lacunosa Zone (NN 19) is present in Core $2(62.0-71.5 \mathrm{~m})$, with well-preserved abundant nannofossils; Coccolithus pelagicus, Cyclococcolithus leptoporus, Discolithina japonica, and Pontosphaera pacifica are frequent.

The lower Pliocene is represented in Cores 3 and 4 $(138.0-223.5 \mathrm{~m})$. Core 3 probably belongs to the stratigraphic interval of the Discoaster asymmetricus/ Reticulofenestra pseudoumbilica Zone (NN 14/NN 15), and Core 4 to the Ceratolithus tricorniculatus Zone (NN 12). Discoasters occur sporadically within this sequence; they are slightly to strongly overgrown.

The Discoaster quinqueramus Zone (NN 11) of the upper Miocene is present from Core 5 to Core 11 (318.5-442.0 $\mathrm{m})$, and contains many slightly etched and broken nannofossils; the discoasters are strongly overgrown. 
Coccolithus pelagicus, Cyclococcolithus macintyrei, and Reticulofenestra pseudoumbilica are the most frequent species. The variable abundance of discoasters within the Discoaster quinqueramus Zone (NN 11) indicates fluctuations of the water temperatures. Precise age determination on nannofossils for the sequence from Core 12 to Core $15(442.0-480.0 \mathrm{~m})$ is difficult. It probably belongs to the middle Miocene on the basis of discoasters, which are similar to Discoaster exilis and the presence of the great variety of Coccolithus pelagicus $( \pm C$. miopelagicus). Nannofossils are abundant but etched and partially broken. Discoasters are scarce to missing; the few specimens observed are strongly overgrown and their determination uncertain.

The Discoaster exilis Zone (NN 6) of the middle Miocene is recognized from Core 16 to Core $19(480.5-518.0)$ with Coccolithus abisectus, Discoaster exilis, a great variety of Coccolithus pelagicus and the oval variety of Coronocyclus nitescens (see Müller, this volume). Nannofossils are plentiful but slightly to strongly etched and broken. Discoasters are scarce and siliceous microfossils become more frequent.

The Sphenolithus heteromorphus Zone (NN 5) of the lower middle Miocene is represented from Core 20 to Sample 23-4, 21-22 cm (518.0-553.0 m). Strongly etched and broken nannofossils are abundant and siliceous microfossils are more frequent. Few reworked Eocene species occur within this sequence. The lower Miocene is encountered from Core 24 to Core $27(556.0-594.0 \mathrm{~m})$. Precise determination of the zones is not possible because index species are absent; a few specimens of Helicosphaera ampliaperta are present in Core 24 together with Sphenolithus heteromorphus, indicating the Helicosphaera ampliaperta Zone (NN 4). The scarcity to near absence of Helicosphaera ampliaperta may be due to dissolution. Badly preserved nannofossils are frequent, as are diatoms. Sphenolithus belemnos was not observed.

The Oligocene/Miocene boundary is drawn between Core 27 and Core 28 on the basis of the extinction of Helicosphaera recta; sphenoliths are missing. The Sphenolithus ciperoensis Zone (NP 25) of the upper Oligocene is determined from Samples 28-1, 34-35 cm to $32-2$, 15-17 $\mathrm{cm}$, and is based on the presence of Triquetrorhabdulus carinatus, which becomes frequent in several samples. Coccolithus pelagicus, C. abisectus, Reticulofenestra lockeri, and Cyclococcolithus floridanus are the most frequent species. Chiasmolithus altus is absent within the Sphenolithus ciperoensis Zone (NP 25). Dictyococcites dictyodus is rare. Etched and broken nannofossils are abundant; siliceous microfossils are present.

The sequence between Samples 32-4, 95-96 cm and 36-1, $107-108 \mathrm{~cm}$ belongs to the Sphenolithus distentus Zone (NP 24 ) of the middle Oligocene. Nannofossils are abundant but badly preserved. Siliceous microfossils are absent from Sample 33-4, 30-31 cm downwards where nannofossils are larger than those from the upper Oligocene/lower Miocene. Dictyococcites dictyodus, Zygrhablithus bijugatus, Coccolithus abisectus, and Cyclococcolithus floridanus abound whereas species of the genus Reticulofenestra are fewer. This fact may suggest a change of water temperature. The nannoplankton assemblage with Discoaster deflandrei and Chiasmolithus altus is comparable with the assemblage of the middle Oligocene from the Norwegian-Greenland Sea and the North Atlantic (DSDP Leg 12).

A hiatus representing an interval of about $8 \mathrm{~m} . \mathrm{y}$. (including the lower part of the middle Oligocene and the lower Oligocene) lies between Samples 36-1, 107-108 cm and 36-2, 27-28 cm. The Sphenolithus distentus Zone (NP $24)$ is underlain by the upper Eocene Isthmolithus recurvus/Sphenolithus pseudoradians Zones (NP 19/NP 20). A subdivision of the two is not possible because Sphenolithus pseudoradians was not observed. This combined zone lies between Samples 36-2, 27-28 cm and 42-1, 102-104 cm. Badly preserved nannofossils are frequent and several samples are poor in them because of recrystallization. Siliceous microfossils are locally common. Discoasters and Isthmolithus recurvus are rare; Chiasmolithus oamaruensis becomes abundant in some samples. Cribrocentrum reticulatum, Reticulofenestra umbilica, and Dictyococcites dictyodus are the most common species. Reworked middle Eocene species occur in several layers, and slumped middle Eocene sediments (NP 14) are intercalated in the upper Eocene sequence of Core 41, Section 5.

The Chiasmolithus oamaruensis Zone (NP 18) is determined from Samples 42-2, $15-16 \mathrm{~cm}$ to $45, \mathrm{CC}$ (730.0-765.0 m) where Chiasmolithus oamaruensis is frequent in some samples. Reworked middle Eocene species are present in the displaced sediments of this section. In Sample 45, CC, the upper Eocene (NP 18) is underlain by the middle Eocene Discoaster sublodoensis Zone NP 14; the hiatus marks an interval of about $6.5 \mathrm{~m}$.y. The Discoaster sublodoensis Zone (NP 14), recovered from Samples 45, $\mathrm{CC}$ to 52 , CC $(765.0-831.0 \mathrm{~m})$, contains numerous nannofossils which are more or less etched. Siliceous microfossils are missing. Discoaster sublodoensis is abundant in the upper part of the zone, whereas Discoaster lodoensis is rare throughout the sequence. Chiasmolithus solitus, Transversopontis pulcher, and Reticulofenestra umbilica are the most significant species.

\section{Dinoflagellates ${ }^{3}$}

Sample 49-1, 111-113 cm yields an assemblage strongly dominated by Thalassiphora pelagica, with no diagnostic species of Zone IVb (Costa and Müller, 1978). The middle Eocene (Zone IVb) is represented by Samples 49-1, 65-67 $\mathrm{cm}$, to Core 46 . The assemblages are equivalent to those from the mid to upper part of the Bracklesham Beds. They are rich and diversified and appear to contain mixed contemporaneous material because preservation is variable in a single sample. The peak abundance of Achomosphaera membraniphora and Phthanoperidinium in Core 48 correlates with Cores 13 and 12 at Site 405. Membranilarnacia ursulae is dominant in Section 47-1, and Spiniferites and Micrhystridium dominate in Section 46-3.

The upper Eocene is represented by Cores 45 to 41 . Zone V, with Spiniferites mirabilis and Distatodinium spp., appears in Section 45-4. The dominant genera throughout the interval are Spiniferites, Operculodinium, and Systematophora. The age of these assemblages appears to be equivalent to the Upper Barton and Headon Beds of Eng-

${ }^{3}$ See Footnote 2. 
land. Dinocysts dominate but diversity is somewhat poorer than in the middle Eocene. The environment appears to be distal (bathyal).

The middle Oligocene is identified in Cores 36 and 33 with Zone VI. This is marked by the appearance of $1 \mathrm{~m}$ pletosphaeridium sp. I, Manum (1976). The assemblages are poorer in species than the Eocene ones. Section 36-1 is dominated by Spiniferites and Apteodinium spiridioides, and Section 33-1 by Operculodinium, Spiniferites, and Cannosphaeropsis.

The upper Oligocene, represented by Zone VIIa, is identified in Section 29-2. This yields a rich assemblage dominated by Impletosphaeridium and includes Forma A (= “'Thalassiphora delicata,"' sensu Manum, 1976; = "'T. cf. pelagicia" sensu Habib, 1971). The proportion of conifer pollen increases in this assemblage.

The Miocene is represented by Cores 24 to 9 . Core 24 yields the lower Miocene Zone VIIb, closely similar to the uppermost upper Oligocene Zone VIIa; the assemblage is dominated by Micrhystridium and Spiniferites; conifer pollen is relatively abundant. Zone VIII, middle and upper Miocene, occurs in Cores 23 to 9 . The assemblages in Cores 23 and 20 are richly diversified, but diversity and abundance of dinocysts is considerably reduced in Cores 16 and 9 (upper middle Miocene and upper Miocene, respectively). Spiniferites, Cannosphaeropsis, Operculodinium, and Micrhystridium are dominant in Zone VIII.

Reworking of near contemporaneous material is common in the middle Eocene. Reworking of Cretaceous material (most likely Senonian) is present throughout. Lower Eocene reworking is also recognized in upper Eocene to Miocene assemblages.

The Thermal Alteration Index of indigenous palynomorphs is low (1-1.5) throughout the sequence.

\section{PHYSICAL PROPERTIES}

\section{Site 405}

Determinations of physical properties at Site 405 (in addition to downhole logs of spontaneous potential, gamma ray, density, porosity, sound speed, and resistivity) involve 67 samples from 407 meters of hole for an average of one sample per 6.1 meters or one sample per 2.5 meters for the bottom 113 meters of hole. The introduction to this volume includes discussion of purpose and procedures for these measurements and related calculations.

The ranges of determinations on cores include: coring time $(0.2-8.6 \mathrm{~min} / \mathrm{m})$, sound speed $(1.53-2.62 \mathrm{~km} / \mathrm{s})$, wet bulk density $\left(1.22-2.03 \mathrm{~g} / \mathrm{cm}^{3}\right)$, sound impedance $(1.96-5.1$ units), porosity (26-84\%), and water content (20-68\%). The data presentation is shown in Table 5 and depth plots on the superlogs in the pocket of this volume.

Between the ocean bottom and sub-bottom depth of 120 meters the changes in physical properties parallel changes in the per cent $\mathrm{CaCO}_{3}$ including a possible seismic reflector at a depth of 50 meters. After two abrupt decreases and an intervening increase in the top 10 meters of ooze, the $\mathrm{CaCO}_{3}$ content increases from about 10 per cent to 85 per cent at 50 meters depth and then decreases to 20 per cent at 110 meters where the content of $\mathrm{SiO}_{2}$ (estimated from smear slides) increases to about 25 per cent. Highs in both sound speed and density coincide with lows in porosity and water content. The sound impedance increases to a maximum of 3 units at the 50 meter depth followed by a decrease to 2 units at 110 meters.

Between sub-bottom depths of 280 and 407 meters, fluctuations in physical properties apparently result from variations in silicification of mudstones including a probable seismic reflector at 285 meters sub-bottom depth. Increases in sound speed and wet bulk density (along with decreases in porosity and water content) multiplied together produce an abrupt sound impedance increase from 2.5 to nearly 5 units between depths 285 and 295 meters.

The downhole logs suggest another possible seismic reflector at about 250 meters sub-bottom apparently coincident with the rock change from siliceous mudstone to calcareous mudstone. The formation density increases abruptly from about 1.4 to 1.7 grams per cubic centimeter where the porosity decreases from 65 to 55 per cent. The other logs also show this change of formation.

\section{Site $\mathbf{4 0 6}$}

Determinations of physical properties at Site 406 (in addition to downhole logs of spontaneous potential, gamma ray, density, porosity, sound speed, and resistivity) involve 167 samples from 8.41 feet of hole for an average of one sample per 5 meters, or one sample per 2.5 meters for the 389 meters of hole between depths 414 and 803 .

The ranges of determinations on cores include: coring time $(0.4-14.8 \mathrm{~min} / \mathrm{m})$, sound speed $(1.6-3.96 \mathrm{~km} / \mathrm{s})$, wet bulk density $\left(1.49-2.49 \mathrm{~g} / \mathrm{cm}^{3}\right)$, sound impedance $(2.59$ 9.78 units), porosity (22-77\%), and water content $(9-52 \%)$. Data presentation is shown in Table 6 and depth plots on the superlogs in the pocket of this volume.

Compaction apparently controls the gradual changes in physical properties measured on cores from the top 500 meters of the hole below the ocean bottom. Nearly pure carbonate sediments show decreases (from top to bottom) in porosity and water content where the sound speed and wet bulk density increase.

Between sub-bottom depths of 500 and 765 meters wide fluctuations in physical properties result from variations in $\mathrm{CaCO}_{3}$, diatomite, and $\mathrm{SiO}_{2}$ cement, including probable seismic reflectors at depths of about 645 meters and 675 meters. Between depths of 500 and 555 meters the onset of sound speed anisotropy and increase in sound speed apparently results from silica cementation where the per cent $\mathrm{CaCO}_{3}$ decreases, without change in wet bulk density and only slight decreases in porosity and water content. The trend of increasing per cent $\mathrm{CaCO}_{3}$ between depths of 610 and 690 meters causes parallel decreases in porosity and water content and increases in both sound speed and wet bulk density which combine to form probable seismic reflectors at 645 and 675 meters. Diatomite in the intervals from 560 to 605 and 690 to 712 meters causes decreases in sound speed and wet bulk density, along with increases in porosity and water content as well as extremes in soundspeed anisotropy up to 26 per cent. Interbeds of diatomite with siliceous chalk produce the extreme flucutations in physical properties evident in the 690 to 712 meter interval.

The physical properties of the 712 to 760 and 760 to 841 meter intervals show sharp contrasts related to the change 
TABLE 5

Physical Property Summary, Site 405

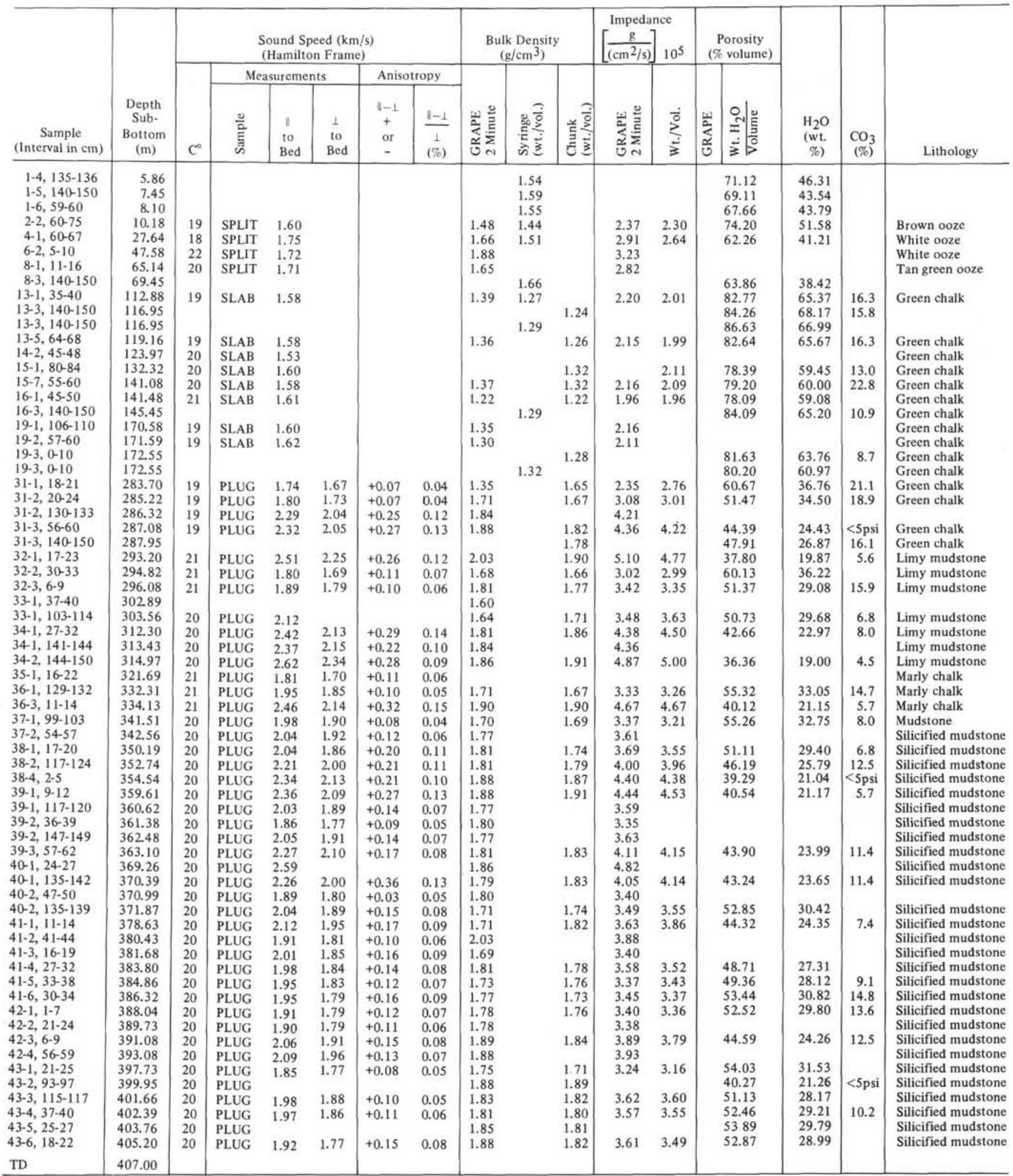


TABLE 6

Physical Property Summary, Site 406

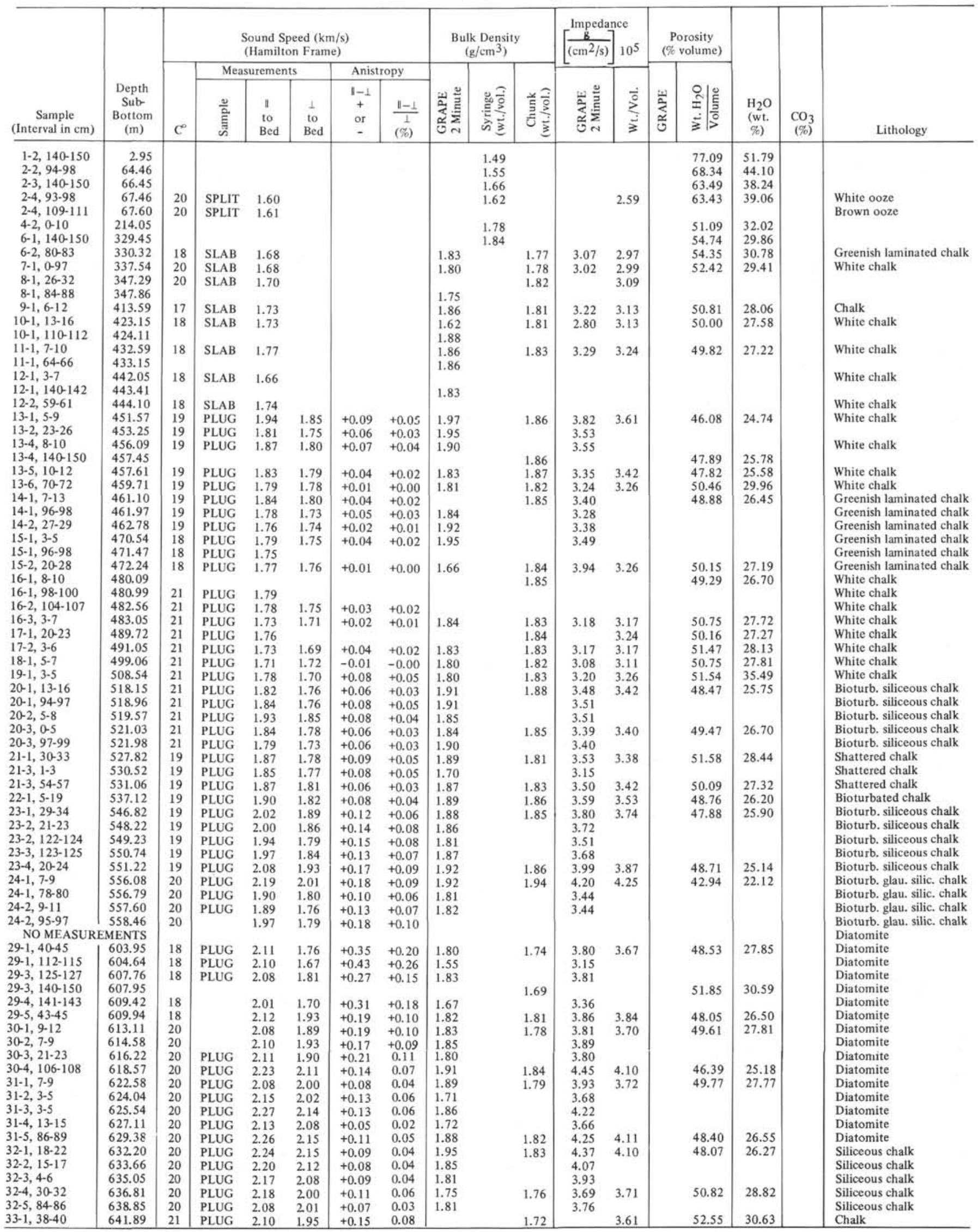


TABLE 6 - Continued

\begin{tabular}{|c|c|c|c|c|c|c|c|c|c|c|c|c|c|c|c|c|}
\hline & & & & $\begin{array}{l}\text { Sound } \\
\text { (Hamil }\end{array}$ & $\begin{array}{l}\text { eed }(k r \\
\text { n Fram }\end{array}$ & & & & $\begin{array}{l}\text { k Densi } \\
\left.\mathrm{g} / \mathrm{cm}^{3}\right)\end{array}$ & & $\begin{array}{l}\text { Impedan } \\
{\left[\frac{\mathrm{g}}{\left(\mathrm{cm}^{2} / \mathrm{s}\right)}\right]}\end{array}$ & $10^{5}$ & & $\begin{array}{l}\text { rosity } \\
\text { olume) }\end{array}$ & & \\
\hline & & & Mea & suremer & & Anist & opy & & & & & & & & & \\
\hline $\begin{array}{c}\text { Sample } \\
\text { (Interval in cm) }\end{array}$ & $\begin{array}{l}\text { Depth } \\
\text { Sub- } \\
\text { Bottom } \\
\text { (m) }\end{array}$ & $\mathrm{C}^{\circ}$ & हूँ & $\begin{array}{l}\| \\
\text { to } \\
\text { Bed }\end{array}$ & $\begin{array}{l}1 \\
\text { to } \\
\text { Bed }\end{array}$ & $\begin{array}{c}t-1 \\
+ \\
\text { or } \\
-\end{array}$ & $\frac{\frac{1-1}{1}}{(\%)}$ & 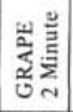 & 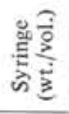 & 至官 & $\frac{\infty}{0} \frac{e}{\Sigma}$ & $\sum_{j}^{3}$ & 这 & 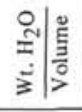 & $\begin{array}{l}\mathrm{H}_{2} \mathrm{O} \\
\text { (wt. } \\
\% \text { ) }\end{array}$ & $\begin{array}{c}\mathrm{CO}_{3} \\
(\%)\end{array}$ \\
\hline $33-1,116-118$ & 642.67 & 21 & PLUG & & & & & 1.91 & & & & & & & & \\
\hline $33-2,10-12$ & 643.11 & 21 & PLUG & 2.28 & 2.18 & +0.10 & 0.05 & 1.82 & & & 4.15 & & & & & \\
\hline $33-3,12-14$ & 644.63 & 21 & PLUG & 2.36 & 228 & +0.08 & 0.04 & 2.05 & & & 4.84 & & & & & \\
\hline $33-3,134-136$ & 645.85 & 21 & PLUG & 2.41 & 2.24 & +0.17 & 0.08 & 2.21 & & & 5.33 & & & & & \\
\hline $33-4,28-31$ & 646.30 & 21 & PLUG & 2.48 & 2.34 & +0.14 & 0.06 & 2.16 & & 2.11 & 5.36 & 5.23 & & 33.33 & 15.77 & \\
\hline $34-1,21-23$ & 651.22 & 20 & PLUG & 2.60 & 2.53 & +0.07 & 0.03 & 2.01 & & 1.97 & 5.23 & 5.12 & & 41.04 & 20.83 & \\
\hline $34-2,5-7$ & 652.56 & 20 & PLUG & 2.48 & 2.28 & +0.20 & 0.09 & 2.19 & & & 5.43 & & & & & \\
\hline $34-3,15-17$ & 654.16 & 20 & PLUG & 2.24 & 2.06 & +0.18 & 0.09 & 2.59 & & & 5.80 & & & & & \\
\hline $343,92-94$ & 654.93 & 20 & PLUG & 2.66 & 2.47 & +0.15 & 0.06 & 2.22 & & & 5.82 & & & 41.42 & 20.98 & \\
\hline $34-4,8-10$ & 655.59 & 20 & PLUG & 2.47 & 2.38 & +0.09 & 0.04 & 2.05 & & 1.97 & 5.06 & 4.87 & & & & \\
\hline $35-1,17-19$ & 660.68 & 20 & PLUG & 2.37 & 2.30 & +0.07 & 0.03 & 2.08 & & 2.07 & 4.93 & 4.91 & & 37.47 & 18.11 & \\
\hline $35-1,111-113$ & 661.62 & 20 & PLUG & 2.23 & 2.18 & +0.05 & 0.02 & 1.97 & & & 4.39 & & & & & \\
\hline $35-2,58-61$ & 662.60 & 20 & PLUG & 2.40 & 2.27 & +0.13 & 0.06 & 2.07 & & & 4.97 & & & & & \\
\hline $36-1,13-17$ & 670.15 & 20 & PLUG & 2.56 & 2.47 & +0.09 & 0.04 & 2.08 & & 2.12 & 5.32 & 5.43 & & 34.70 & 16.33 & \\
\hline $36-1,106-109$ & 671.08 & 20 & PLUG & 2.42 & 2.29 & +0.13 & 0.06 & 2.09 & & & 5.06 & & & & & \\
\hline $36-2,27-30$ & 671.79 & 20 & PLUG & 2.51 & 2.30 & +0.27 & 0.12 & 1.99 & & & 5.11 & & & & & \\
\hline $36-2,98-101$ & 672.50 & & PLUG & 2.30 & 225 & +0.05 & 0.02 & 2.04 & & & 4.69 & & & & & \\
\hline $36-3,91-94$ & 673.93 & 20 & PLUG & 2.24 & 220 & +0.04 & 0.02 & 2.03 & & 1.97 & 4.55 & 4.41 & & 42.67 & 21.68 & \\
\hline $37-1,13-16$ & 679.65 & 20 & PLUG & 2.77 & 2.55 & +0.22 & 0.09 & 2.22 & & 2.17 & 6.15 & 6.01 & & 29.11 & 13.38 & \\
\hline $37-2,12-14$ & 681.13 & 20 & PLUG & 2.77 & 262 & +0.15 & 0.06 & 2.20 & & & 6.09 & & & & & \\
\hline $37-3,32-34$ & 682.83 & 20 & PLUG & 2.81 & 2.58 & +0.23 & 0.09 & 2.30 & & & 6.46 & & & & & \\
\hline $37-4,48-50$ & 684.49 & 20 & PLUG & 2.98 & 274 & +0.24 & 0.09 & 2.32 & & & 6.91 & & & & & \\
\hline $37-5,66-72$ & 686.19 & 20 & PLUG & 2.79 & 2.65 & +0.11 & 0.04 & 2.21 & & 2.18 & 6.10 & 6.02 & & 29.00 & 13.33 & \\
\hline $38-1,9-12$ & 689.02 & 20 & PLUG & 2.81 & 2.64 & +0.17 & 0.06 & 2.26 & & 2.15 & 6.35 & 6.04 & & 28.62 & 13.30 & \\
\hline $38-1,96-98$ & 689.97 & 20 & PLUG & 3.04 & 2.90 & +0.14 & 0.05 & 2.33 & & & 7.08 & & & & & \\
\hline $38-2,9-11$ & 690.60 & 20 & PLUG & 2.88 & 247 & +0.41 & 0.17 & 2.39 & & & 6.88 & & & & & \\
\hline $38-2,116-118$ & 691.67 & 20 & PLUG & 2.95 & 2.70 & +0.25 & 0.09 & 2.36 & & & 6.96 & & & & & \\
\hline $38-3,29-31$ & 692.30 & 20 & PLUG & 2.90 & 2.51 & +0.39 & 0.16 & 2.08 & & & 6.03 & & & & & \\
\hline $38-3,103-105$ & 693.04 & 20 & PLUG & 2.58 & 2.28 & +0.30 & 0.13 & 1.95 & & & 5.03 & & & & & \\
\hline $38-4,18-20$ & 693.69 & 20 & PLUG & 2.14 & 1.92 & +0.22 & 0.11 & 1.79 & & 1.73 & 3.83 & 3.70 & & 46.30 & 26.75 & \\
\hline $38-4,102-104$ & 694.53 & 20 & PLUG & 2.04 & 1.70 & +0.34 & 0.20 & 1.70 & & & 3.47 & & & & & \\
\hline $38-5,10-12$ & 695.11 & 20 & PLUG & 6.60 & 2.10 & +0.50 & 0.24 & 1.97 & & & 5.12 & & & & & \\
\hline $38-5,117-119$ & 696.18 & 20 & PLUG & 2.73 & 2.45 & +0.28 & 0.11 & 2.20 & & & 6.01 & & & & & \\
\hline $39-1,9-15$ & 698.62 & 20 & PLUG & 2.91 & 2.56 & +0.35 & 0.14 & 2.26 & & 2.18 & 6.58 & 6.34 & & 26.71 & 12.26 & \\
\hline $39-1,125-127$ & 699.76 & 20 & PLUG & 2.09 & 1.91 & +0.18 & 0.09 & 1.89 & & & 3.95 & & & & & \\
\hline $39-2,31-33$ & 700.32 & 20 & PLUG & 2.96 & 2.69 & +0.30 & 0.11 & 2.22 & & & 6.57 & & & & & \\
\hline $39-2,123-125$ & 701.24 & 20 & PLUG & 2.95 & 2.73 & +0.22 & 0.08 & 2.18 & & & 6.43 & & & & & \\
\hline $39-3,34-36$ & 701.85 & 20 & PLUG & 2.78 & 2.46 & +0.32 & 0.13 & 2.16 & & & 6.00 & & & & & \\
\hline $39-3,122-150$ & 702.86 & 20 & PLUG & 2.67 & 2.28 & +0.39 & 0.17 & 2.05 & & 2.02 & 5.47 & 5.39 & & 33.21 & 16.47 & \\
\hline $39-4,26-31$ & 703.29 & 20 & PLUG & 3.11 & 2.86 & +0.25 & 0.09 & 2.33 & & 2.26 & 7.25 & 7.03 & & 22.34 & 9.89 & \\
\hline $39-4,108-110$ & 704.09 & 20 & PLUG & 2.81 & 246 & +0.35 & 0.14 & 2.16 & & & 6.07 & & & & & \\
\hline $39-5,32-34$ & 704.83 & 20 & PLUG & 2.26 & 2.03 & +0.23 & 0.11 & 2.04 & & & 4.61 & & & & & \\
\hline $39-5,105-104$ & 705.56 & 20 & PLUG & 2.03 & 1.82 & +0.26 & 0.14 & 1.78 & & & 3.70 & & & & & \\
\hline $40-1,37-40$ & 708.39 & 20 & PLUG & 2.57 & 2.35 & +0.22 & 0.09 & 2.00 & & 2.09 & 5.14 & 5.37 & & 29.37 & 14.08 & \\
\hline $40-2,1-3$ & 709.52 & 20 & PLUG & 2.09 & 1.78 & +0.31 & 0.17 & 1.99 & & & 4.16 & & & & & \\
\hline $40-2,81-84$ & 710.33 & 20 & PLUG & 2.12 & 1.77 & +0.35 & 0.20 & 1.77 & & 1.69 & 3.75 & 3.58 & & 52.45 & 31.00 & \\
\hline $40-3,11-13$ & 711.12 & 20 & PLUG & 2.99 & 2.57 & +0.42 & 0.16 & 2.29 & & & 6.85 & & & & & \\
\hline $40-3,107-110$ & 712.09 & 20 & PLUG & 3.16 & 273 & +0.43 & 0.16 & 2.44 & & 2.27 & 7.62 & 7.17 & & 21.56 & 9.49 & \\
\hline $41-1,23-25$ & 717.74 & 20 & PLUG & 3.00 & 2.57 & +0.43 & 0.17 & 2.43 & & 2.27 & 7.29 & 6.81 & & 23.40 & 10.29 & \\
\hline $41-1,115-118$ & 718.67 & 20 & PLUG & 3.47 & 3.99 & +0.48 & 0.12 & 2.38 & & & 8.26 & & & & & \\
\hline $41-2,22-24$ & 719.23 & 20 & PLUG & 3.96 & 3.52 & +0.44 & 0.13 & 2.47 & & & 9.78 & & & & & \\
\hline $41-2,125-127$ & 720.26 & 20 & PLUG & 3.12 & 2.84 & +0.28 & 0.10 & 2.49 & & & 7.77 & & & & & \\
\hline $41-3,32-34$ & 720.83 & 20 & PLUG & 2.58 & 2.54 & -0.01 & -0 & 2.26 & & & 5.83 & & & & & \\
\hline $41-3,142-144$ & 721.93 & 20 & PLUG & 2.87 & 267 & +0.20 & 0.07 & 2.46 & & & 7.06 & & & & & \\
\hline $41-4,27-29$ & 722.28 & 20 & PLUG & 3.05 & 2.71 & +0.34 & 0.13 & 2.41 & & & 7.35 & & & & & \\
\hline $41-4,142-145$ & 723.44 & 20 & PLUG & 2.90 & 2.60 & +0.30 & 0.12 & 2.37 & & 2.16 & 6.87 & 6.26 & & 24.22 & 11.20 & \\
\hline $41-5,39-40$ & 723.90 & 20 & PLUG & 2.87 & 2.58 & +0.29 & 0.11 & 2.40 & & & 6.89 & & & & & \\
\hline $41-5,108-110$ & 724.59 & 20 & PLUG & 2.88 & 2.73 & +0.15 & 0.05 & 2.12 & & & 6.11 & & & & & \\
\hline $41-5,145-147$ & 724.96 & 20 & PLUG & 2.03 & 1.89 & +0.14 & 0.07 & 1.91 & & & 3.88 & & & & & \\
\hline $41-6,25-27$ & 725.26 & 20 & PLUG & 2.59 & 2.46 & +0.13 & 0.05 & 2.28 & & & 5.91 & & & & & \\
\hline $42-1,21-25$ & 727.23 & 20 & PLUG & 2.85 & 2.70 & +0.15 & 0.06 & 2.33 & & 2.26 & 6.64 & 6.44 & & 26.68 & 11.82 & \\
\hline $42-1,107-110$ & 728.09 & 20 & PLUG & 2.95 & 2.69 & +0.26 & 0.10 & 2.40 & & & 7.08 & & & & & \\
\hline $42-2,13-16$ & 728.65 & 20 & PLUG & 2.42 & 2.31 & +0.11 & 0.05 & 2.44 & & & 5.90 & & & & & \\
\hline $42-2,135-137$ & 729.86 & 20 & PLUG & 2.47 & 2.38 & +0.09 & 0.04 & 2.42 & & & 5.98 & & & & & \\
\hline $42-3,46-48$ & 730.47 & 20 & PLUG & 2.65 & 2.58 & +0.07 & 0.03 & 2.30 & & & 6.10 & & & & & \\
\hline $42-3,141-143$ & 731.42 & 20 & PLUG & 2.35 & 2.27 & +0.08 & 0.04 & 2.33 & & & 5.48 & & & & & \\
\hline $42-4,18-22$ & 731.70 & 20 & PLUG & 2.49 & 2.43 & +0.06 & 0.02 & 2.49 & & 2.25 & 6.20 & 5.60 & & 26.76 & 11.91 & \\
\hline $43-1,3-5$ & 736.54 & 20 & PLUG & 2.89 & 2.82 & +0.07 & 0.02 & 2.36 & & & 6.82 & & & & & \\
\hline $45-1,42-44$ & 755.93 & 20 & PLUG & 2.71 & 2.58 & +0.13 & 0.05 & 2.15 & & 2.20 & 5.83 & 5.96 & & 27.57 & 12.52 & \\
\hline $45-2,15-17$ & 757.16 & 20 & PLUG & 2.84 & 2.66 & +0.18 & 0.07 & 2.23 & & & 6.33 & & & & & \\
\hline $45-2,116-118$ & 758.17 & 20 & PLUG & 2.51 & 2.37 & +0.14 & 0.06 & 2.21 & & & 5.55 & & & & & \\
\hline $45-3,40-42$ & 758.91 & 20 & PLUG & 2.36 & 2.30 & +0.06 & 0.03 & 1.91 & & & 4.51 & & & & & \\
\hline $45-3,116-118$ & 759.67 & 20 & PLUG & 2.57 & 2.46 & +0.11 & 0.04 & 2.24 & & & 5.76 & & & & & \\
\hline $45-3,140-150$ & 759.95 & & & & & & & 2.14 & & 1.86 & & & & 47.38 & 25.50 & \\
\hline $45-4,22-24$ & 760.23 & 20 & PLUG & 2.51 & 2.41 & +0.10 & 0.04 & & & & & & & & & \\
\hline $45-4,101-103$ & 761.02 & 20 & PLUG & 2.72 & 2.61 & +0.11 & 0.04 & & & & & & & & & \\
\hline $45-5,26-34$ & 761.80 & 20 & PLUG & 2.52 & 2.48 & +0.04 & 0.02 & 2.00 & & 1.99 & 5.04 & 5.01 & & 41.74 & 21.02 & \\
\hline $46-1,61-64$ & 765.63 & 21 & PLUG & 2.14 & 2.06 & +0.08 & 0.04 & 2.14 & & 2.36 & 4.58 & 5.05 & & 56.52 & 21.23 & \\
\hline $46-3,78-80$ & 768.79 & 21 & PLUG & 2.13 & 1.96 & +0.17 & 0.09 & 2.01 & & 2.02 & 4.28 & 4.30 & & 41.65 & 20.59 & \\
\hline
\end{tabular}


TABLE 6 - Continued

\begin{tabular}{|c|c|c|c|c|c|c|c|c|c|c|c|c|c|c|c|c|c|}
\hline \multirow[b]{3}{*}{$\begin{array}{c}\text { Sample } \\
\text { (Interval in } \mathrm{cm} \text { ) }\end{array}$} & \multirow[b]{3}{*}{$\begin{array}{l}\text { Depth } \\
\text { Sub- } \\
\text { Bottom } \\
\text { (m) }\end{array}$} & \multicolumn{6}{|c|}{$\begin{array}{l}\text { Sound Speed }(\mathrm{km} / \mathrm{s}) \\
\text { (Hamilton Frame) }\end{array}$} & \multicolumn{3}{|c|}{$\begin{array}{l}\text { Bulk Density } \\
\left(\mathrm{g} / \mathrm{cm}^{3}\right)\end{array}$} & \multicolumn{2}{|c|}{$\left[\frac{\mathrm{g}}{\left(\mathrm{cm}^{2} / \mathrm{s}\right)}\right]_{10}^{\text {Impedance }}$} & \multicolumn{2}{|c|}{$\begin{array}{c}\text { Porosity } \\
\text { (\% volume) }\end{array}$} & \multirow[b]{3}{*}{$\begin{array}{c}\mathrm{H}_{2} \mathrm{O} \\
\text { (wt. } \\
\% \text { ) }\end{array}$} & \multirow[b]{3}{*}{$\begin{array}{c}\mathrm{CO}_{3} \\
(\%)\end{array}$} & \multirow[b]{3}{*}{ Lithology } \\
\hline & & \multirow[b]{2}{*}{$\mathrm{C}^{\circ}$} & \multicolumn{3}{|c|}{ Measurements } & \multicolumn{2}{|c|}{ Anistropy } & \multirow[b]{2}{*}{ 植总 } & \multirow[b]{2}{*}{ 离苍 } & \multirow[b]{2}{*}{ 总咅 } & \multirow[b]{2}{*}{ 苮兽 } & \multirow[b]{2}{*}{$\sum_{j}^{\dot{j}}$} & \multirow[b]{2}{*}{$\frac{1}{3}$} & \multirow[b]{2}{*}{ 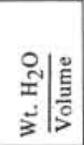 } & & & \\
\hline & & & 总 & $\begin{array}{l}1 \\
\text { to } \\
\text { Bed }\end{array}$ & $\begin{array}{c}1 \\
\text { to } \\
\text { Bed }\end{array}$ & $\begin{array}{c}\|-1 \\
+ \\
\text { or } \\
-\end{array}$ & $\frac{1-1}{\frac{1}{1}}$ & & & & & & & & & & \\
\hline $47-1,29-31$ & 774.80 & 22 & PLUG & 2.05 & 1.86 & +0.19 & 0.10 & 1.98 & & 1.94 & 4.06 & 3.98 & & 46.89 & 24.20 & & Green claystone \\
\hline $47-5,5-7$ & 780.56 & 22 & PLUG & 2.05 & 1.93 & +0.12 & 0.06 & 1.93 & & 2.00 & 3.96 & 4.10 & & 43.04 & 21.47 & & Green claystone \\
\hline $48-1,0-5$ & 784.03 & 21 & PLUG & 2.03 & 1.86 & +0.17 & 0.09 & 1.99 & & 1.96 & 4.04 & 3.98 & & 45.09 & 23.01 & & Green claystone \\
\hline $48-1,128-130$ & 785.29 & 21 & PLUG & 2.05 & 1.88 & +0.17 & 0.09 & 2.04 & & & 4.18 & & & & & & Green claystone \\
\hline $48-2,57-59$ & 786.08 & 21 & PLUG & 2.04 & 1.84 & +0.20 & 0.11 & 1.98 & & & 4.04 & & & & & & Green claystone \\
\hline $48-3,130-132$ & 788.31 & 21 & PLUG & 2.06 & 1.91 & +0.15 & 0.08 & 2.12 & & & 4.37 & & & & & & Green claystone \\
\hline $48-4,67-68$ & 789.18 & 21 & & & & & & & & 1.99 & & & & 44.23 & 22.21 & & Green claystone \\
\hline $49-1,3-5$ & 793.54 & 21 & PLUG & 2.08 & 1.93 & +0.17 & 0.09 & 2.02 & & 2.03 & 4.20 & 4.22 & & 41.03 & 20.26 & & Green claystone \\
\hline $49-2,23-25$ & 795.24 & 21 & PLUG & 2.09 & 1.93 & +0.16 & 0.08 & 2.12 & & & 4.43 & & & & & & Green claystone \\
\hline $50-1,3-8$ & 803.06 & 21 & PLUG & 2.09 & 1.89 & +0.20 & 0.11 & 2.06 & & 1.98 & 4.31 & 4.14 & & 43.86 & 22.16 & & Green claystone \\
\hline
\end{tabular}

from limestone to claystone. The limestones in contrast to the claystones show much higher sound speed and wet bulk density, and lower porosity and water content.

\section{DOWNHOLE LOGGING RESULTS, SITE 405} D. Mann

The following logs were run: borehole compensated sonic/gamma ray/caliper (BHCS/GR/CAL), compensated neutron/formation density/gamma ray (CNL/FDC-gr), and induction 6FF40/spherically focused $\log / \mathrm{gamma}$ ray/ spontaneous potential (ISF/GR/SP).

The maximum limit of the eccentralizer on the neutron/ density tool is 12 inches and readings are unreliable when the hole exceeds this diameter. Where tool contact with the side of the hole is poor, so are the readings. The hole at Site 405 is oversize down to 3280.0 meters $(297.0 \mathrm{~m})^{4}$; the sonic log records only borehole velocities down to 3222.0 meters $(239.0 \mathrm{~m})$ and is not included in Figure 12. The latter is a composite of the main logging curves depth matched against cores, and a generalized stratigraphic description; the main logging breaks are also superimposed on the figure. (In the oversize hole, the density reads close to $1.4 \mathrm{~g} / \mathrm{cm}^{3}$ which is close to the lower limit of resolution for scale settings of the analog print.)

Figure 13 shows how the drilled core results match those determined from the logs. Where depth discrepancies appear artificial, a double arrow marking has been used. Other logging markers that may have lithological/sedimentological significance have been additionally marked in the logging depth column. Physical properties measurements, especially those relating to velocity, have helped considerably in the log to core correlation by peak-to-peak matching with sonic $\log$. The SP proved useful in helping to confirm suggested logging breaks.

\section{Log Interpretation}

\section{Sub-Unit 1A (2983.0-3028.6 m [0-45.0 m])}

Only the gamma-ray log through drill pipe was recorded through this section. Sea bed is seen on the gamma-ray

\footnotetext{
${ }^{4}$ All depths quoted refer either to depths marked on the logging runs using the density/neutron as the base lot or their equivalent sub-sea-bottom depths.
}

curve at $2983.0(0 \mathrm{~m})$ by a reduction to almost nil units API and entry from the drill pipe at 3087.5 meters $(104.5 \mathrm{~m})$. From 3008.0 meters $(25.0 \mathrm{~m})$ to 3017.0 meters $(34.0 \mathrm{~m})$ there is an increase from 5 to 15 API units on the GR indicating a higher clay mineral content. This is not seen in core descriptions but physical properties measurements confirm the clay mineral content in the range of 40 to 50 per cent. The lithology is mainly marly to non-marly foraminifer nannofossil ooze. No clear break is seen on the GR to mark the base of the sub-unit and the curve remains rather flat. Clay mineral content from the physical properties measurements however suggests a more marked fall off in clay mineral content at the lower boundary.

\section{Sub-Unit 1B (3028.0-3048.0 m [45.0-65.0 m])}

The gamma ray remains flat at around 5 API units confirming $\mathrm{CaCO}_{3}$ as the predominant constituent. The lithology is mainly nannofossil ooze-foraminifer nannofossil ooze in which $\mathrm{CaCO}_{3}$ content reaches up to 97 per cent. No clearly defined base of this sub-unit is seen on the GR $\log$.

\section{Sub-Unit 2A (3048.0-3083.0 m [65.0-100.0 m])}

A prounounced lithologic change at top of Sub-unit $2 \mathrm{~A}$ is not readily apparent and the GR shows little character. The lithology is mainly foraminifer nannofossil ooze, nannofossil ooze, and siliceous nannofossil ooze. $\mathrm{CaCO}_{3}$ content falls markedly towards the base of the section while clay mineral content rises to in excess of 70 per cent.

\section{Sub-Unit 2B (3083.0-3228.0 m [100.0-245.0 m])}

The physical properties log confirms the top of this unit to be dominated by clay. Due to hole size difficulties, little information can be inferred from the logging runs down to $3222.0(239.0 \mathrm{~m})$. At this depth, a prominent hiatus is recognized on all the logs which would appear to mark the base of Sub-unit 2A. The density log shows a marked increase from around $1.4 \mathrm{~g} / \mathrm{cm}^{3}$ (close to the lower limit of resolution) to 1.6 to $1.7 \mathrm{~g} / \mathrm{cm}^{3}$; the sonic $\log$ indicates other than purely borehole velocities. The main lithology difference accounting for these changes appears to lie in the increasing silicification of the rocks noted in Cores 26 and 14. The physical properties measurements and neutron log show a marked reduction in porosity from this boundary (Figure 18). 


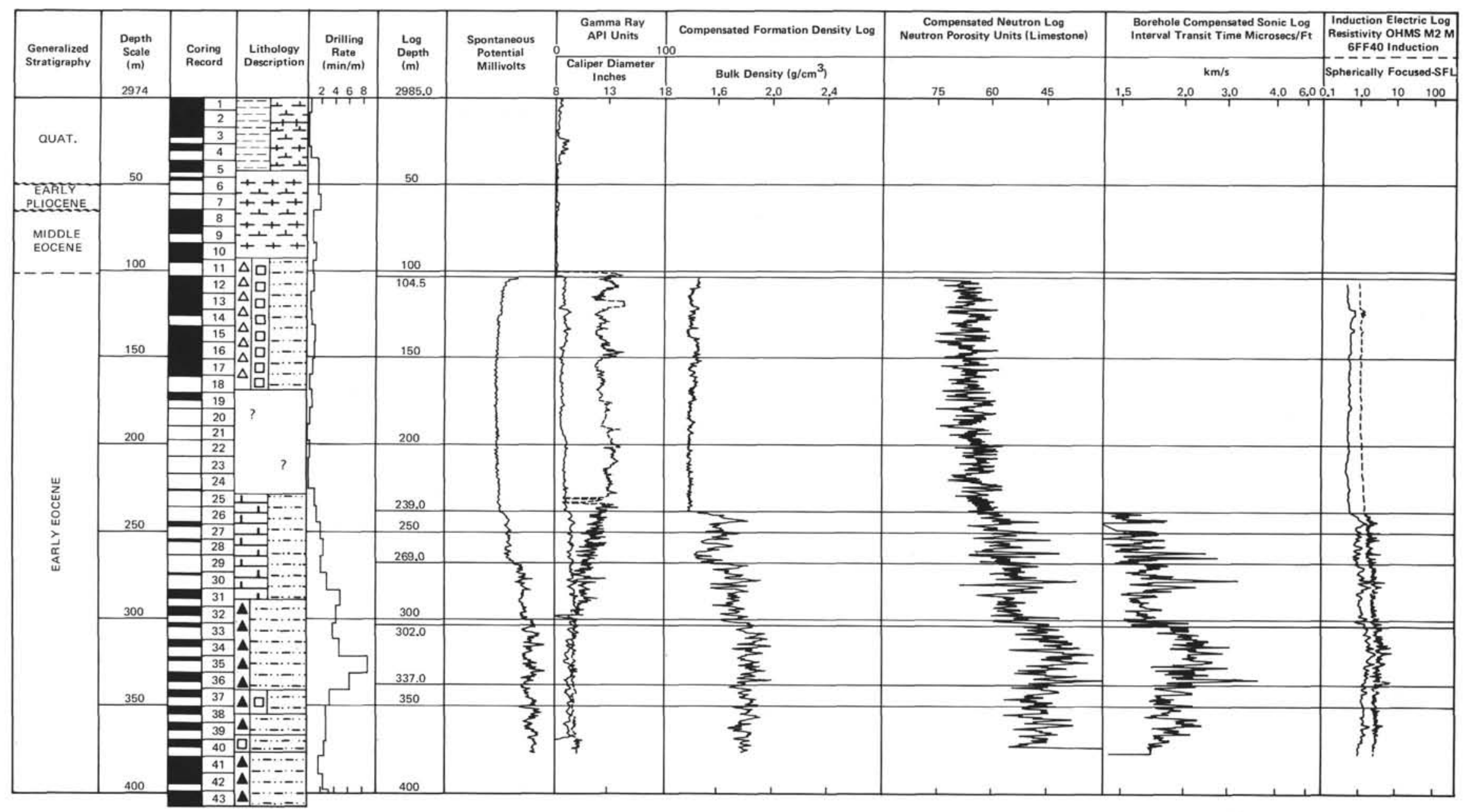

Figure 12. Site 405: Downhole logs and generalized stratigraphy with principal logging breaks. 


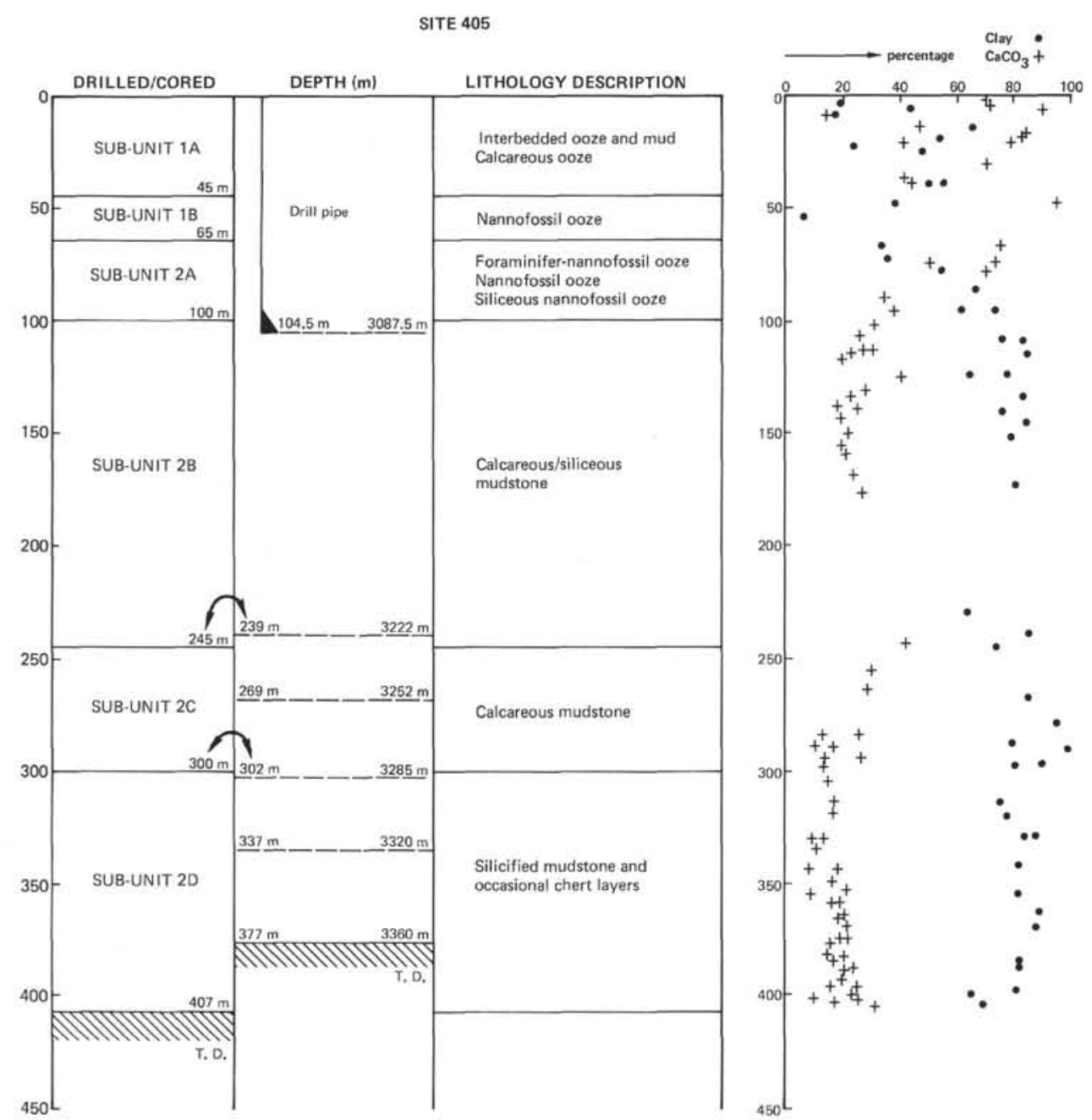

Figure 13. Correlation of lithologic units and logging breaks, Site 405.

The predominant lithology is calcareous siliceous mudstone and is distinguished from units above and below by the abundance of siliceous biogenous remains (avg. $20-30 \%$ of the sediment and ranging up to $40 \%$ ).

\section{Sub-Unit 2C (3228.0-3283.0 m [245.0-300.0 m])}

At 3222.0 meters $(239.0 \mathrm{~m})$ more silicified material appears with an increase in the clay component of the rock; siliceous biogenous remains disappear. Clay content lies in the range of 60 to 70 per cent and the GR rises to a value of around 20 API units. The lithology is mainly siliceous calcareous mudstone. Peaks on the sonic and density, allied to the accompanying troughs in neutron readings, occur opposite reductions in the GR readings, suggesting interbedded tighter, less porous bands of material. Core recovery was relatively poor in Sub-unit $2 \mathrm{C}$ but the logging curves infer an interbedded sequence. Hard beds occur mostly against troughs in the gamma-ray curve. These tight bands are clearly seen in the core material of Cores 31 and 32. Silica also appears in the form of cementing agent in the rock fabric and as chert interbedded with the more calcareous mudstone. The interbedded chert bands are clearly seen in Cores 31 and 32 , but the resolution of the logging tools is insufficient to pick out the individual bands.
At 3252.0 meters $(269.0 \mathrm{~m})$ the density/neutron and SP logs indicate some change in response and although there are superimposed hole effects, this is probably partly due to changes in porosity of the rock material.

\section{Sub-Unit 2D (3283.0-3390.0 m [300.0-407.0 m]) (Figure 15)}

Substantial change in log response from 3285.0 meters $(302.0 \mathrm{~m})$ downwards occurs. Sonic velocities show a marked increase and density values move to a higher range, probably due to a continuing increase in silicification. Laminae are common as are chert bands and interbeds. This depth marks the base of Sub-unit 2C.

Opal becomes a prominent constituent from Core 33 to Core 40 (ranging from $10 \%$ up as high as $75 \%$ ). Interbedding of harder and relatively softer material is seen by the ragged appearance of the logging curves down to 3320.0 $(337.0 \mathrm{~m})$ where the alternation, as seen on the sonic $\log$, becomes less marked. With minor exceptions this lithology continues through to 3360.0 meters $(377.0 \mathrm{~m})$ the lowest recorded depth on the logs.

In view of the somewhat similar lithologies encountered in both Sub-units $2 \mathrm{C}$ and $2 \mathrm{D}$, the best core-to-log match has been made by comparing and translating peak-to-peak velocities from the physical properties measurements onto 


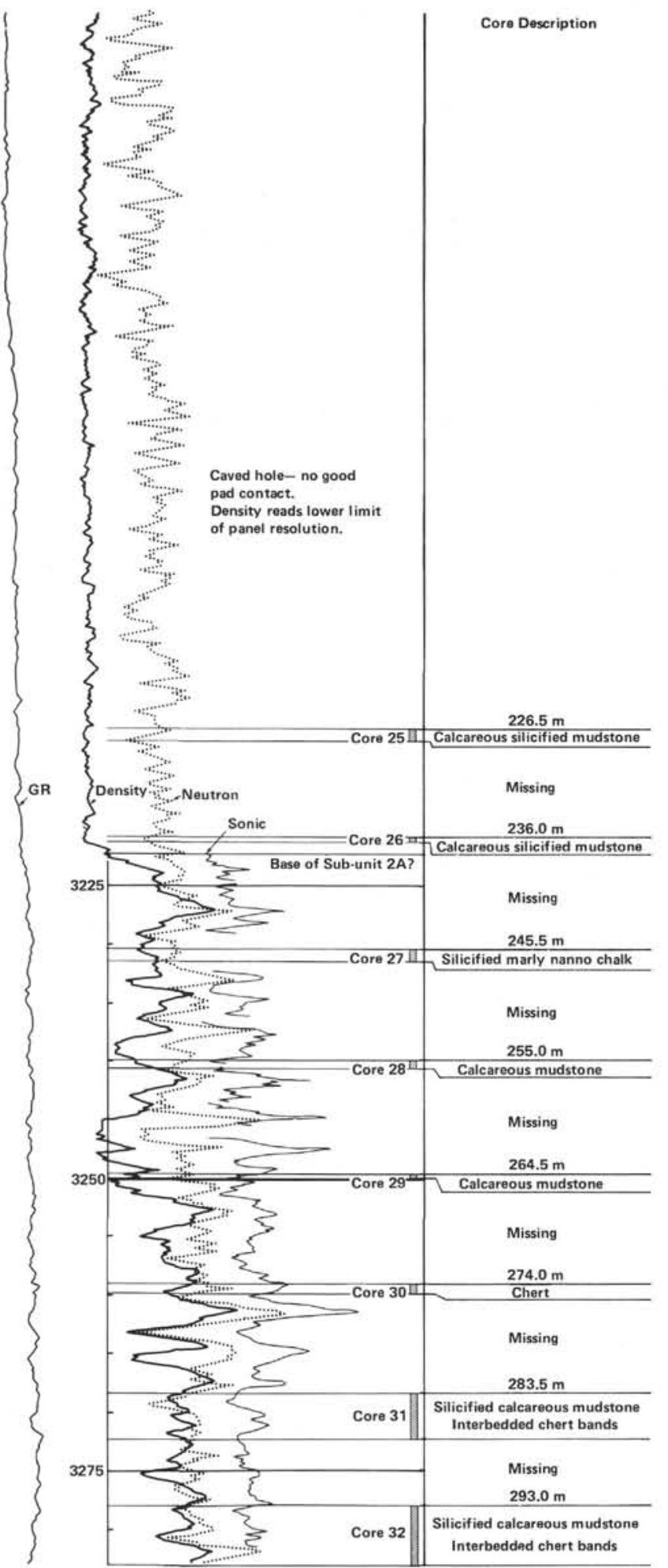

Figure 14. Interlog comparison, Site 405, 2335.0 to 3275.0 meters, Sub-unit $2 B$.

the sonic $\log$ (see Figure 15). The significant points on the neutron density and sonic logs are apparent on the induction/focused resistivity logs.

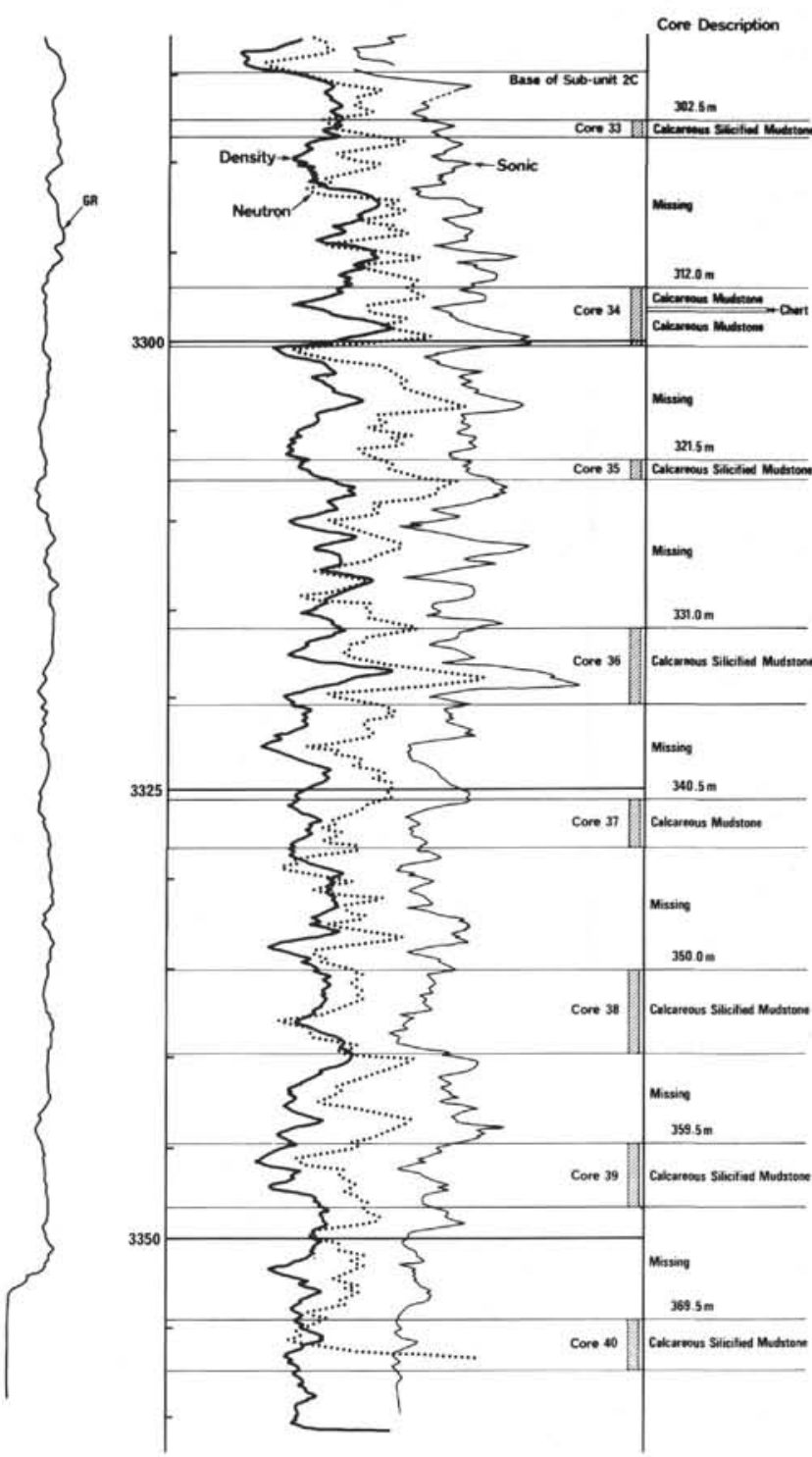

Figure 15. Interlog comparison, Site $405,3275.0$ to 3360.0 meters, Sub-unit $2 D$.

\section{Crossplots}

The crossplots have proved of limited use on this well due to enlarged borehole down to 3222.0 meters $(239.0 \mathrm{~m})$ and to somewhat similar lithologies from 3222.0 meters to total depth; discrimination of the plots is much reduced, but some examples of the crossplots are included.

Superimposition of lithoporosity " $\mathrm{Z}$ " plot—gamma-ray relative intensity (Figure 16, 3088.0-3360.0 m [105.0$377.0 \mathrm{~m}]$ ) shows clearly the trend of readings in the upper part of the hole where fluid velocities predominate (3088.0-3222.0 $\mathrm{m}[195.0-239.0 \mathrm{~m}])$. The tendency of this plot is to give a wider scatter when borehole conditions are poor.

Superimposed density versus sonic " $\mathrm{Z}$ " plotgamma-ray relative intensity (Figure 17, 3088.0$3360.0 \mathrm{~m}$ [105.0-377.0 m]) shows the superposition of a large number of points of similar values around $1.4 \mathrm{~g} / \mathrm{cm}^{3}$ 
near the lower limit of panel resolution on the density device. Some distinction of lithology trends is seen on passing from Sub-units $2 \mathrm{C}$ to $2 \mathrm{D}$; this is shown on the figure.

Figure 18 shows density versus neutron ' $Z$ '" plot gamma-ray relative intensity logs superimposed (3088.0$3360.0 \mathrm{~m}$ [105.0-377.0 m]). This plot again shows a large number of points in the corridor around $1.4 \mathrm{~g} / \mathrm{cm}^{3}$; the lithology trend passing from Sub-units $2 \mathrm{C}$ to $2 \mathrm{D}$ is indicated on the figure.

\section{Conclusions}

1) Little information can be inferred from the logs in the oversized borehole down to 3222.0 meters $(239.0 \mathrm{~m})$.

2) The well-marked onset of silicification is clearly shown by a marked hiatus on all the logs at 269.0 meters.

3) The well-developed peak and trough appearance on the sonic density and neutron curves over the interval 3222.0 meters $(239.0 \mathrm{~m})$ to 3360.0 meters $(377.0 \mathrm{~m})$ indicates interbedded material of harder and relatively softer material (chert layers in otherwise dominantly calcareous mudstone or silicified calcareous mudstone).

4) Discrimination on crossplots is poor where borehole conditions are poor and similar lithologies are encountered.

5) Difficulty occurs in matching cores and logs where lithologies are similar and core recovery is poor. Especially in Sub-units 2C and 2D, peak-to-peak translation of the physical properties velocity measurements are made against the sonic curve for best fit.

\section{DOWNHOLE LOGGING RESULTS, SITE 406}

At Site 406, the following logs were run: Borehole Compensated Sonic/Caliper (BHCS/CAL), Variable Density Log (VDL), Compensated Neutron/Formation Density/Gamma Ray (CNL/FDC/GR), Induction 6FF40/ Electric Log/Short Normal/SP (IES/SN/SP). The gammaray $\log$ on the sonic run failed and the only gammaray available is that recorded on the density/neutron run.

The density/neutron log shows a cyclic rhythmicity down to 3250.0 meters $(356.0 \mathrm{~m})$ with a period of about 10 meters on the density log. The rhythmicity continues down to 3585.0 meters $(691.0 \mathrm{~m})$ but the period appears to change to around 6 meters. The readings appear to be a function of hole conditions and are not related directly to lithology. The sonic $\log$ is less affected by these borehole conditions.

In discussion of the lithological units and sub-units, all data were taken from the shipboard site summaries. Figure 19 shows the match between lithology and the logging. Where depth discrepancies appear artificial a double arrow is used. Other logging markers which may have lithological/sedimentological significance have been additionally marked in the depth column. The SP suffers from magnetism and bimetallism and is of limited use. The physical properties log agrees well with the Schlumberger logs throughout the section and provides a good tie between the lithology and downhole logs.

\section{Log Interpretation}

Figure 20 is a composite of the main logging curves depth matched against cores, and a generalized stratigraphic description. No gamma-ray curve was available between entry into the drill pipe and the sea bed. Entry into the pipe was recorded on the density/neutron $\log$ at 3022.0 meters $(128.0 \mathrm{~m})$.

Sub-Unit 1A (2894.0-2965.5 m [0-71.5 m])

No logs were recorded over this interval.

\section{Sub-Unit 1B (2965.5-3032.9 m [71.5-138.0 m])}

The only supporting evidence for the base of the sub-unit at 138.0 meters appears on the short normal electric log at 3033.0 meters $(139.0 \mathrm{~m})$. Although there is an increase in the density reading at the same depth, enlarged hole conditions discount its reliability. The sonic curve reads mainly fluid velocities as far down as 3058.0 meters (in the range of 194-202 $\mu \mathrm{s}$ ). No cores were taken over this interval.

\section{Sub-Unit 2A (3032.0-3412.0 m [138.0-518.0 m])}

There is no evidence from the logs of any marked change of lithology at 518.0 meters. On the sonic log a general trend of increasing velocity with depth down to 3267.0 meters $(373.0 \mathrm{~m})$ occurs. From this depth downwards the sonic $\log$ reaches a steady value of $145 \mu \mathrm{s}$. This break is supported by a relative deflection on the density/neutron curves and an inflection point on the SP $\log$. Unfortunately, there are no cores covering this junction point, but we speculate that this may make the transition from ooze to chalk by compaction down to 373 meters. There is no marked change in lithology between 373.0 meters and 430.0 meters and the density and sonic values stabilize through to 430.0 meters. At this depth, some evidence of change occurs where the sonic reading moves to a lower median value of $141 \mu$ s and the density reading moves to a slightly higher plateau. No cores were taken.

\section{Sub-Unit 2B (3412.0-3451.0 m [518.0-557.0 m])}

The base of the unit is well defined at 3460.0 meters $(566.0 \mathrm{~m})$; all logs show this to be a major lithological break. Figure 21 shows the density/neutron $\log$ on a 1:200 scale overlain with the sonic curve. Core descriptions have been transferred into the depth column for cross-reference. The figure shows good correlation between the logs and the lithology and physical properties log. The most striking feature of the cores is the uniformly high $\mathrm{CaCO}_{3}$ content and the sharp increase in silica content at the base of the sub-unit. The lithology changes from nannofossil chalk through siliceous nannofossil chalk to calcareous diatomite.

A high GR peak at 3461.0 meters (Core 24) is not explained by an increase in the clay mineral content (smear slides show consistent average clay mineral content in the range $20-25 \%$ ) and may indicate concentration of some radioactive mineral. A scintillometer scan over this core might reveal that the peak is genuine; if so, a spectroscopic analysis to determine which radioactive isotope is present should be made.

\section{Unit 3 (3451.0-3507.0 m [557.0-613.0 m])}

This unit is mainly calcareous diatomite $\left(\mathrm{CaCO}_{3} 35-40 \%\right.$, $\mathrm{SiO}^{2} 50-60 \%$ ). The logs indicate the lower boundary of the unit to be at 3514.0 meters $(620.0 \mathrm{~m})$ which marks the change to calcareous chalk/siliceous calcareous chalk. On the physical properties log, a small transition zone occurs at the merger into Sub-unit $4 \mathrm{~A}$, followed by a sharp and 


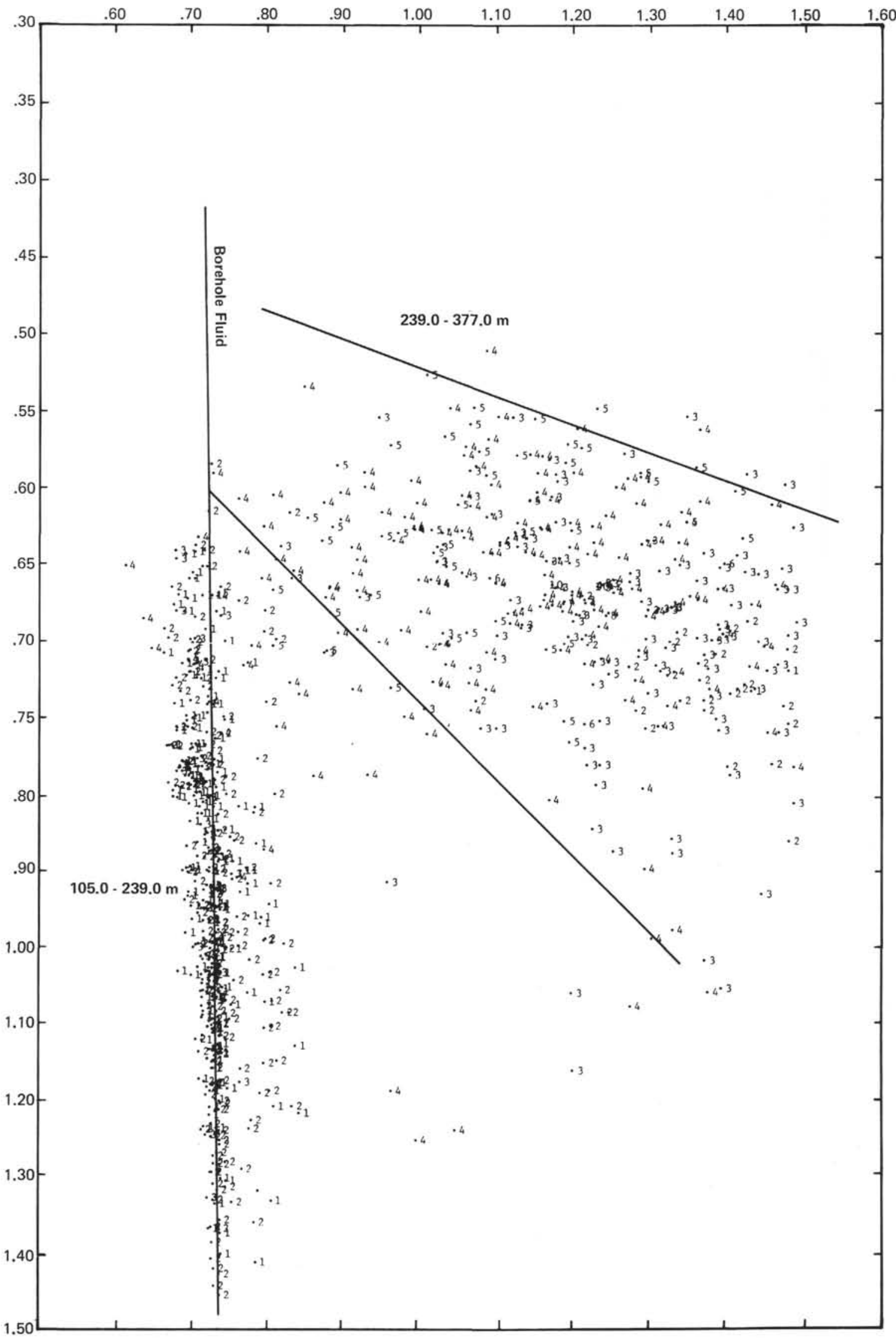

Figure 16. Lithoporosity " $Z$ " plot - gamma-ray relative intensity superimposed 13088.0 to $3360.0 \mathrm{~m}$, 105.0 to $377.0 \mathrm{~m}$ ). 


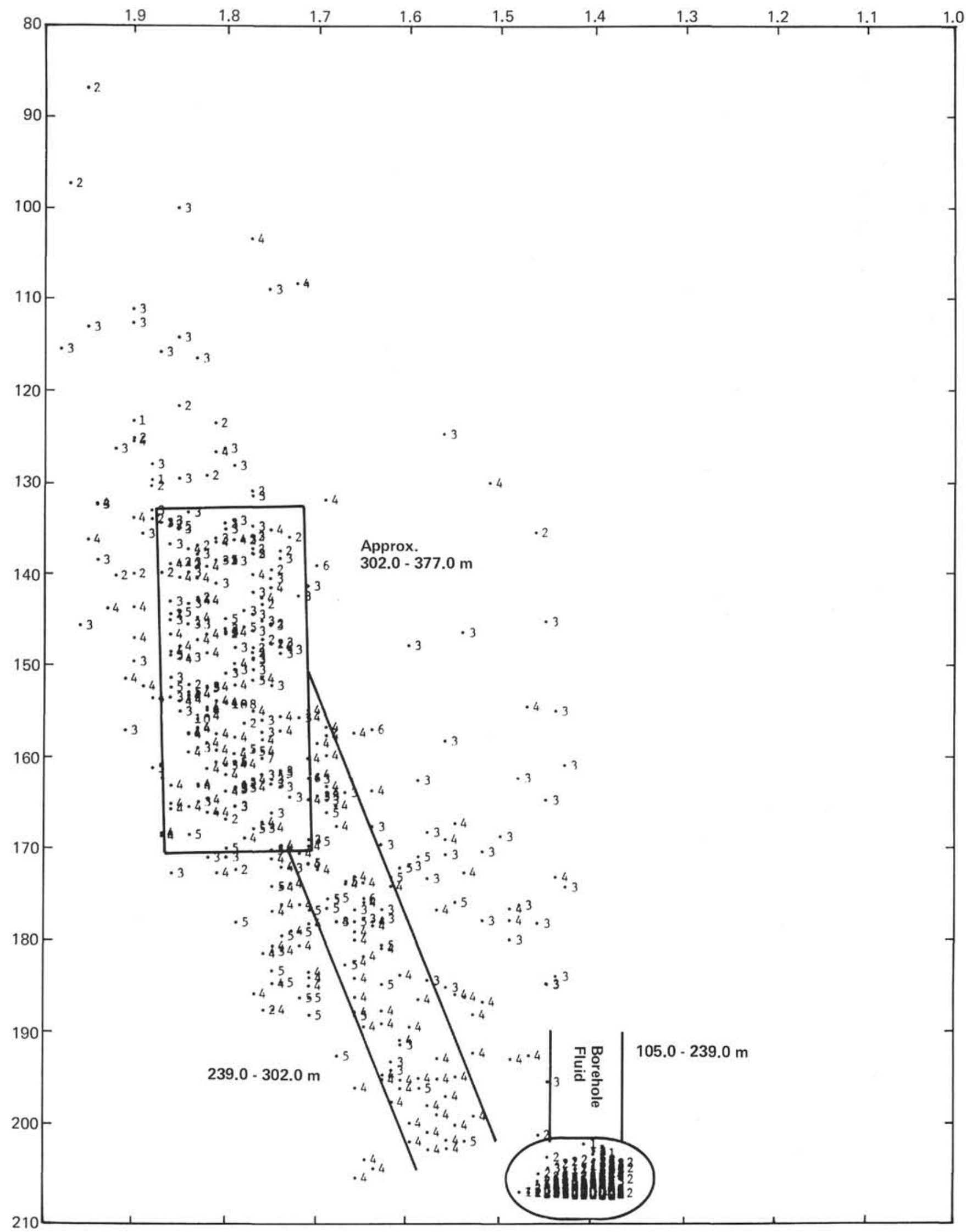

Figure 17. Density versus sonic " $\mathrm{Z}$ " plot - gamma-ray relative intensity superimposed (3088.0 to $3360.0 \mathrm{~m}, 105.0$ to $377.0 \mathrm{~m}$ ). 


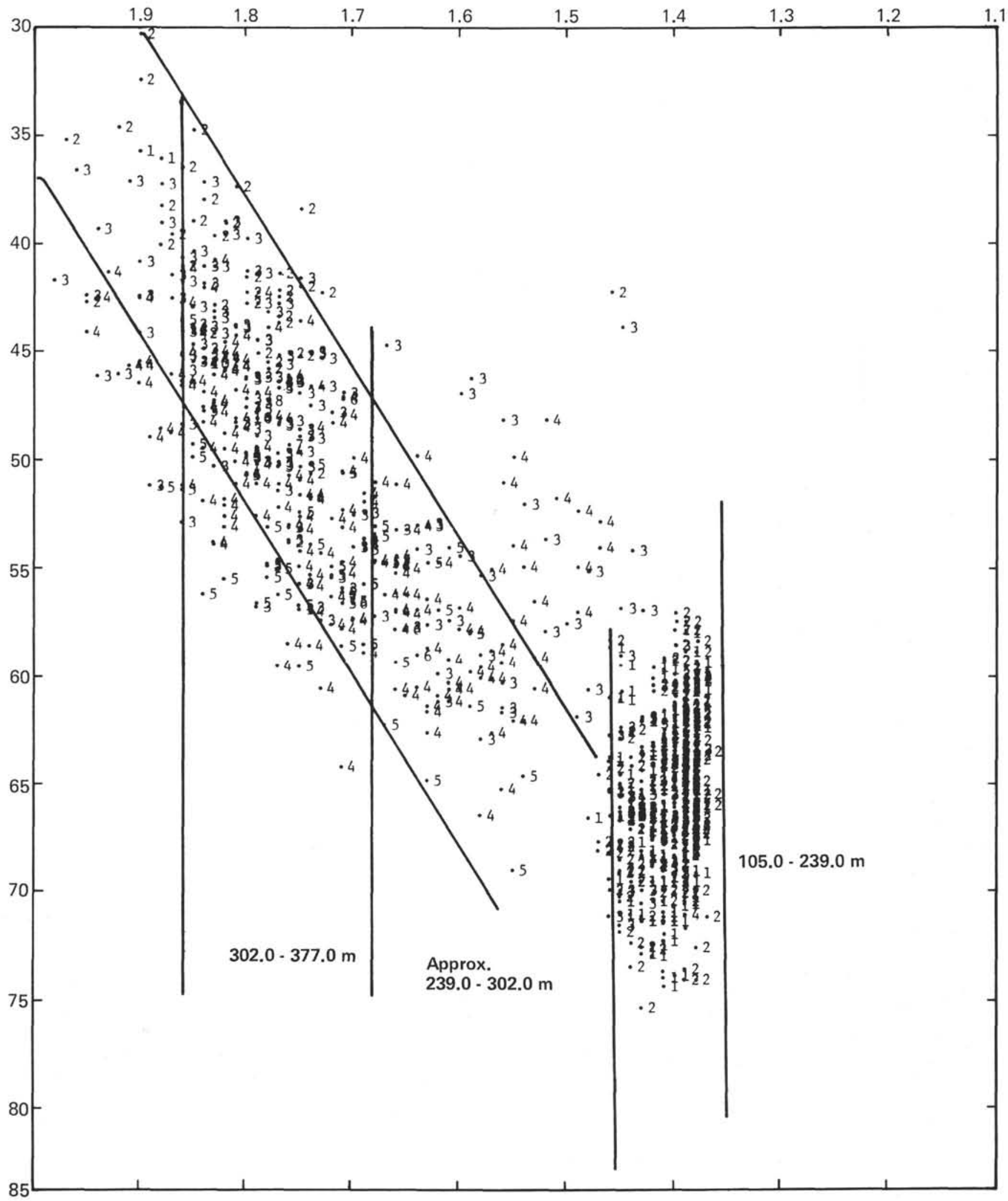

Figure 18. Density versus neutron " $\mathrm{Z}$ " plot - gamma-ray relative intensity superimposed $(3088.0$ to $3360.0 \mathrm{~m}, 105.0$ to $377.0 \mathrm{~m}$ ). 


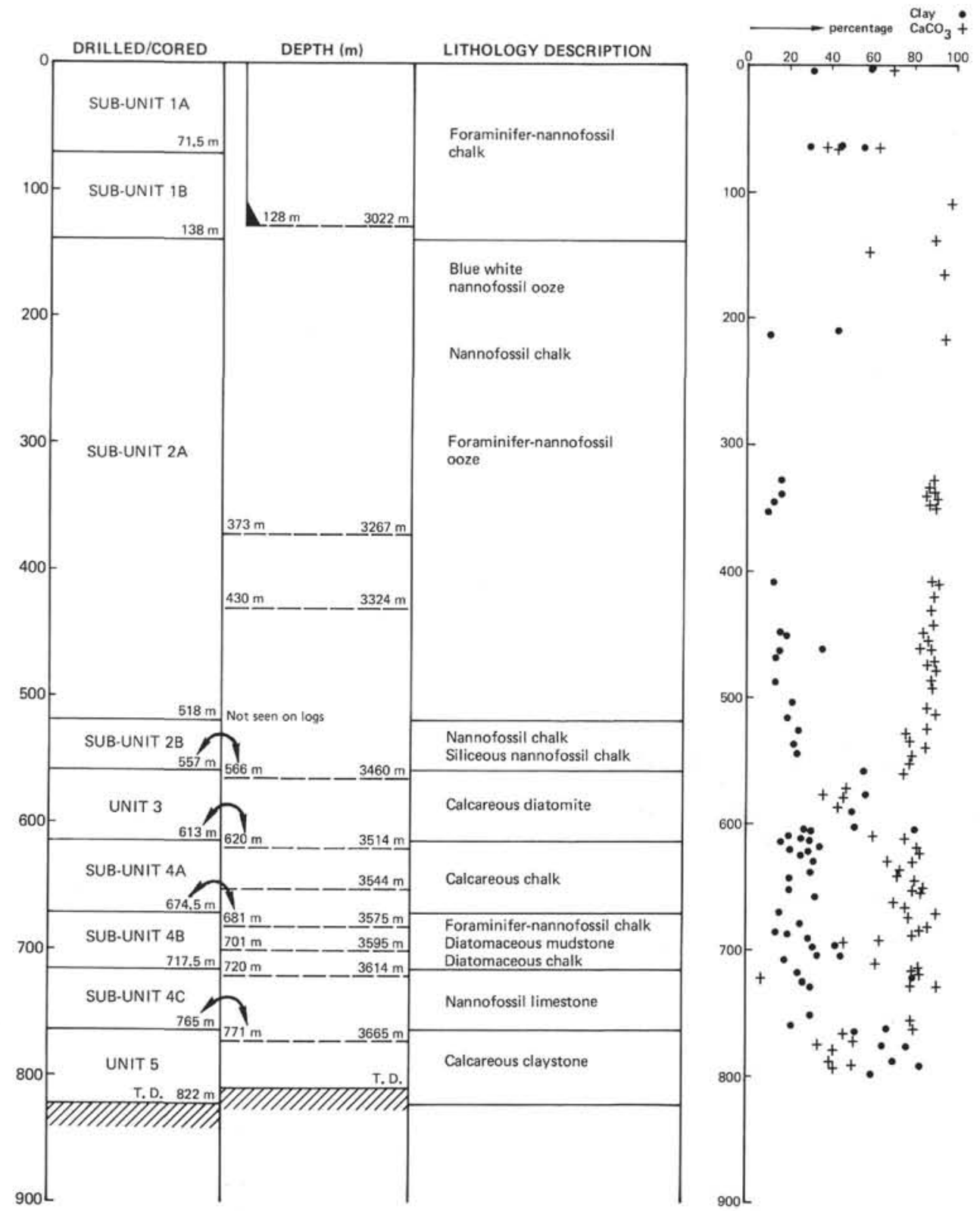

Figure 19. Correlation of lithologic units and logging breaks, Site 406.

continuing rise of $\mathrm{CaCO}_{3}$ content $(\sim 80 \%)$ at the expense of silica which drops to less than 10 per cent.

Velocities measured horizontally and vertically on samples differ, especially at the base of the unit. The cores are laminated and interbedded from 610.0 to 613.0 meters (core depths) but this feature is less obvious on the density/neutron logs because of hole conditions. Shipboard density measurements on samples over the same interval also showed evidence of the interbedding nature of the lithology.

\section{Sub-Unit 4A (3507.0-3565.5 m [613.0-671.5 m])}

The physical properties log indicate a uniformly high $\mathrm{CaCO}^{3}$ content (ca. $75 \%$ ) throughout the section; the main lithology is calcareous chalk. The density, sonic and resistivity values show this unit to be more compacted than
Unit 3 and interbedding is less important towards the base of the sub-unit.

An event of some significance occurs at 3544.0 meters $(650.0 \mathrm{~m})$ and is seen on all logs. Neutron porosity values drop from over 50 per cent to 30 per cent or less, the density increases from around $1.8 \mathrm{~g} / \mathrm{cm}^{3}$ to over $2.0 \mathrm{~g} / \mathrm{cm}^{3}$, sonic velocities increase and resistivity shows a marked increase. These factors point to a reduction in porosity associated with the change from calcareous chalk to nannofossil chalk. This break aligns well with a similar one seen on the physical properties log at 645.0 meters. Some further compaction of the strata may occur below 3544.0 meters, but a cementation effect may also be present. The caliper begins to read undersize below this depth, indicating a build-up of mud cake and that the formation is less friable to the action of the drilling bit. From 3544.0 to 3575.0 meters 


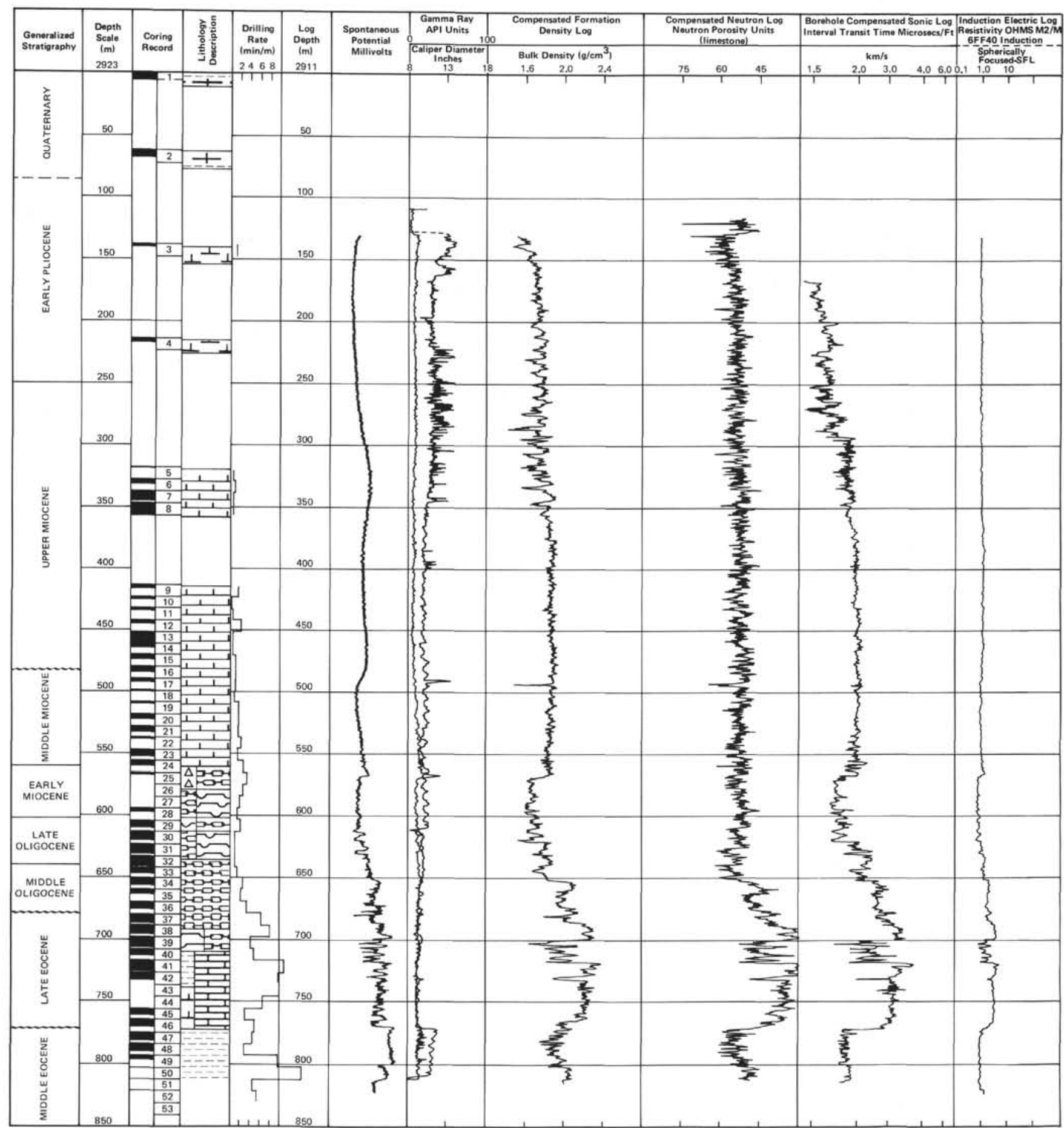

Figure 20. Site 406: Downhole logs and generalized stratigraphy with principal logging breaks.

(653.0-681.0 m) the lithology remains consistent and is mainly calcareous chalk and nannofossil chalk.

\section{Sub-Unit 4B (3565.5-3611.5 m [671.5-717.5 m]) (Figure 22)}

The upper sub-unit boundary shows on the logs at 3575.0 meters $(681.0 \mathrm{~m})$. Between 3575.0 and 3595.0 meters the main lithology consists of foraminifer nannofossil chalk interbedded with calcareous chalk. A steadily decreasing porosity gradient occurs throughout this interval as is shown by all three porosity logs. At 3595.0 meters, there is a marked change in lithology. The break is well characterized on the physical properties log at 693.0 meters (cored depth) by a sharp drop in $\mathrm{CaCO}_{3}$ content accompanied by an increase in silica to around 15 per cent. A continuing layered sequence is seen also on the physical properties log through to 3613.0 meters.

Analysis of the core from 3595.0 to 3613.0 meters $(701.0-719.0 \mathrm{~m})$ shows the reappearance of silica in significant quantities with predominant interbeds of diatomaceous mudstone and calcareous chalk/siliceous calcareous chalk. The fine detail seen in the cores is not apparent on the logs which tend to average these events with 


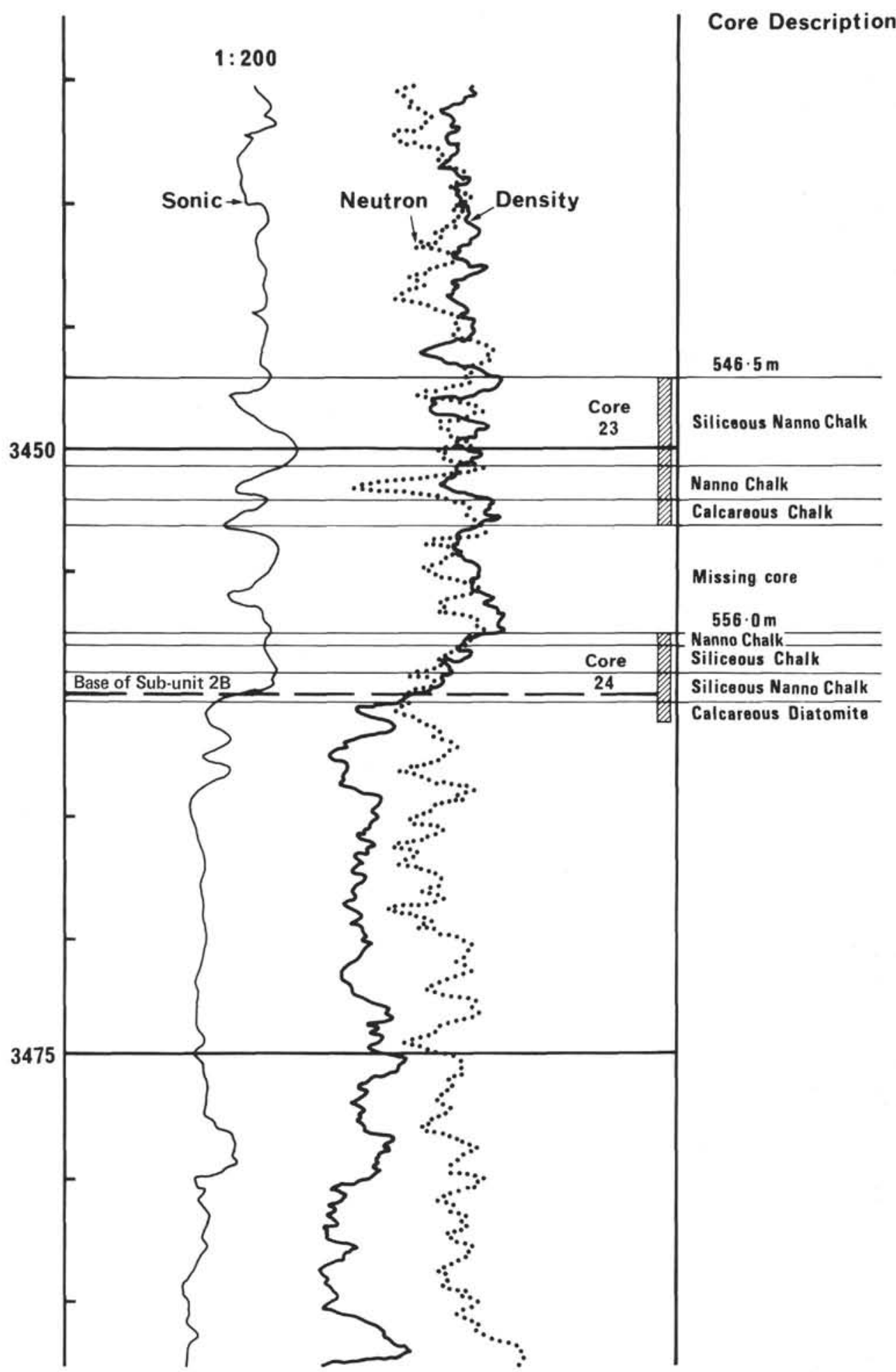

Figure 21. Interlog comparison, Site 406 (Sub-unit 2B, 3435.0 to $3485.0 \mathrm{~m}$ ).

a resolution of about 0.5 meter. It would seem from the logs and physical properties determinations that the interval 3595.0 to 3613.0 meters could well merit a sub-unit status of its own. The lower boundary of Sub-unit 4B appears to have been changed on the physical properties log from that given in the site summary and in this case only the physical properties reference depth has been used.
Sub-Unit 4C (3611.5-3659.0 m [717.5-765.0 m]) (Figure 22)

The logs clearly mark the upper boundary at $3613.0 \mathrm{~m}$ $(719.0 \mathrm{~m})$. Apart from a transition at the top, the remainder of the section shows uniform lithology and the sonic and resistivity curves read near constant values. The density/ neutron readings are broadly similar but suggest an increase 


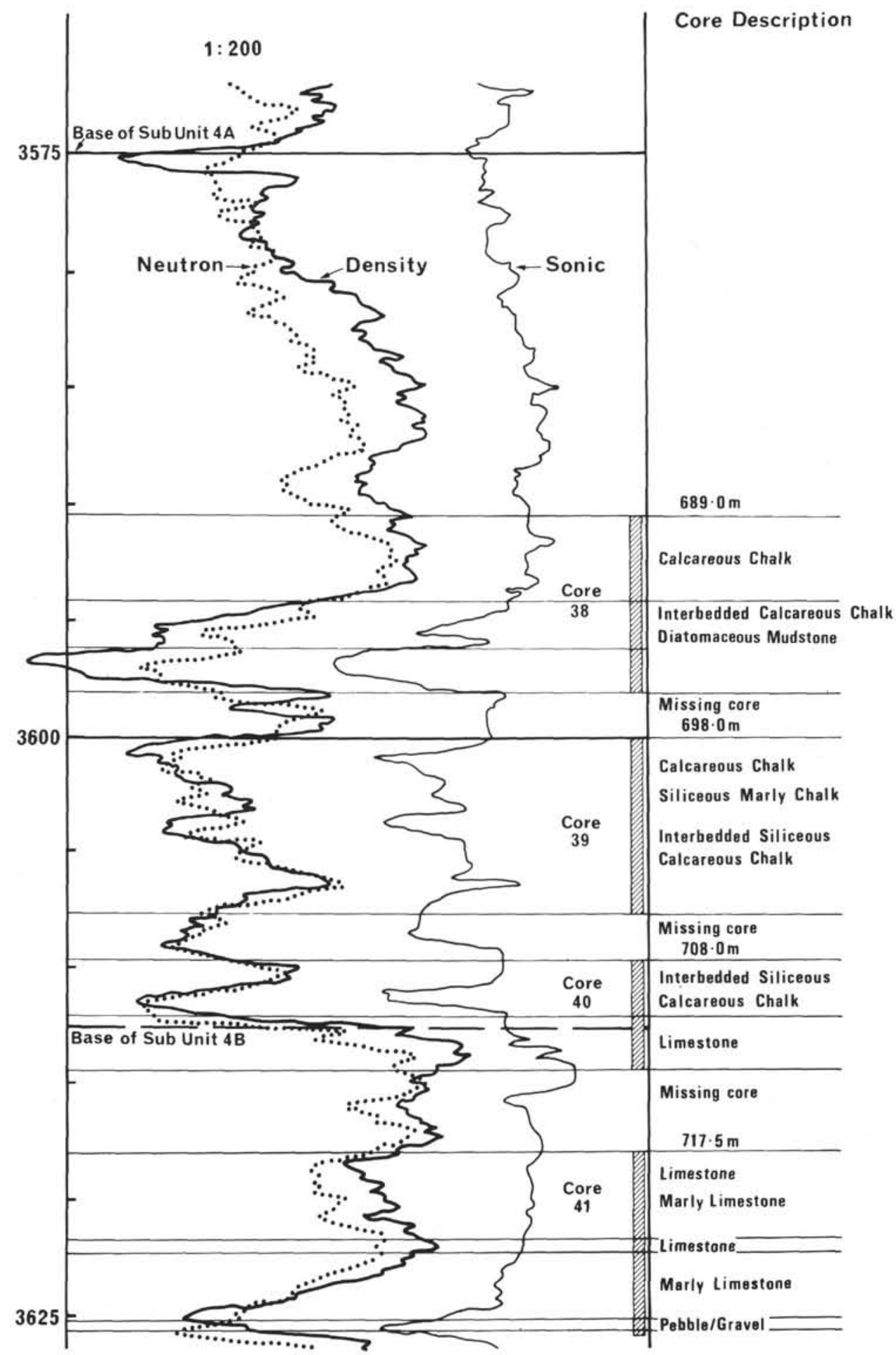

Figure 22. Interlog comparison, Site 406 (Sub-unit $4 B, 3575.0$ to $3625.0 \mathrm{~m}$ ).

in porosity towards the base of the section; the lithology is limestone/marly limestone. The single peak shown on all the logs from 3625.0 to 3626.0 meters is also seen on the physical properties log and correlates with the base of Core 41 , Section 6 which contains the pebble bed.

The entire sub-unit shows a well-developed undersized caliper with a one-quarter inch mud cake development, and exactly straddles the interval, which confirms the homogeneity of the sub-unit.

\section{Unit $5(3659.0-3716.0 \mathrm{~m}[765.0-822.0 \mathrm{~m}])$}

A clear and decisive break on all the logs confirms the upper unit boundary at 3665.0 meters $(771.0 \mathrm{~m})$. The GR moves to a much higher plateau of 32 API units indicating an increase in clay mineral content that is confirmed by the physical properties log. The caliper takes on a ragged appearance although still indicating that many of the layers within the unit are permeable. Visual core descriptions 
confirm the increase in clay content (up to 95\%) and, on the average, a drop in $\mathrm{CaCO}_{3}$ to less than 40 per cent. The sonic $\log$ shows a median value of $154 \mu$ s indicating that the formation is not normally compacted (in logging parlance a reasonable rule of thumb is that a shale, to be considered normally compacted, should have a $\Delta \mathrm{t}$ of less than $100 \mu \mathrm{s})$. The ragged appearance of the sonic caliper suggests that readings are affected by hole conditions. The lithology is mainly laminated calcareous claystone. Sonic values are rather uniform on the 1:200 scale logs but the density/neutron and caliper readings show the interbedded nature of the formation. The logs effectively bottom at around 3710.0 meters.

\section{Crossplots}

The crossplots have been divided into convenient depth zones based on their logging characteristics; a final composite run over all zones shows the general pattern within the well.

Lithoporosity ' 'Z' plot (gamma-ray relative intensity superimposed): Mainly due to poor hole conditions affecting the density/neutron readings this plot was poor in most zones and interpretation was not pursued.

Density versus neutron ' $Z$ ', plot (gamma-ray relative intensity superimposed): Figure $23,3125.0$ to 3230.0 meters (231.0-336.0 m), shows the main group of points where the sonic plateaus. There is considerable peripheral scatter due to hole conditions and absolute values are unreliable throughout the zone.

Figure $24,3230.0$ to 3459.0 meters $(336.0-565.0 \mathrm{~m})$, is similar to Figure 23 above and there is a superimposed cyclicity. Again absolute values are unreliable.

Figure $25,3459.0$ to 3545.0 meters $(565.0-651.0 \mathrm{~m})$, covering Unit 3 and Sub-unit $4 \mathrm{~A}$, indicates points on this plot to be displaced to the right and with slightly higher GR readings (values of 3 and 4 ). The borehole conditions were poor.

Figure 26, 3545.0 to 3658.0 meters $(651.0-764.0 \mathrm{~m})$ covering Sub-units $4 \mathrm{~B}$ and $4 \mathrm{C}$, shows a change to higher density and lower neutron values as borehole conditions improved. The discrimination of the plot becomes more marked and the distinctive lithology of Sub-unit $4 \mathrm{C}$ in the corridor shown is apparent.

Figure $27,3658.0$ to 3702.0 meters $(764.0-808.0 \mathrm{~m})$, shows the well-defined calcareous claystone lithology with the higher GR values of 7,8 and 9. Borehole effects have made most of these plots of little use down to 3512.5 meters $(618.5 \mathrm{~m})$. The composite plot is not included because of its little use.

Density versus sonic " $Z$ "' plot (gamma-ray relative intensity superimposed): This series of plots show the more reliable discrimination of the sonic log compared to the density/neutron results which were badly affected by hole conditions down to 3512.5 meters.

Figure $28,3125.0$ to 3230.0 meters $(231.0-336.0 \mathrm{~m})$, shows the scatter in the density values but a well defined trend towards increasing velocities with depth on the sonic.

Figure $29,3230.0$ to 3462.0 meters $(336.0-568.0 \mathrm{~m})$, shows a remarkably consistent set of sonic readings where the curve plateaus. The scatter at the isolated GR peak of 3461.0 meters is clearly shown by the values 6,9 , and 10 on the plot.
Figure $30,3459.0$ to 3546.0 meters $(565.0-652.0 \mathrm{~m})$, shows the two distinct lithologies of Unit 3 and Sub-unit $4 \mathrm{~A}$. This plot enhances the marked lithology from 3544.0 meters.

Figure $31,3545.0$ to 3658.0 meters $(651.0-764.0 \mathrm{~m})$, shows the course of the plot which takes a different direction from that shown on Figure 33, again confirming the hiatus at 3544.0 meters $(650.0 \mathrm{~m})$. There is considerable scatter in the alternating sequence from 3544.0 to 3612.5 meters. The reappearance of diatomaceous material shows that its association is markedly different from that seen in Unit 3.

Figure $32,3658.0$ to 3702.0 meters $(764.0-808.0 \mathrm{~m})$, clearly shows the calcareous claystone lithology at the base with an abrupt shift of GR intensity from $3 \mathrm{~s}$ and $4 \mathrm{~s}$ to the diagnostic 7,8 , and $9 \mathrm{~s}$ of the basal unit.

Figure $33,3125.0$ to 3702.0 meters $(231.0-808.0 \mathrm{~m})$, is a composite showing that practically all the major zones and units identified separately from the logs can be isolated within the plot.

\section{Conclusions}

1) The SP suffers not only from magnetism but also bimetallism and must be used with extreme caution.

2) The density/neutron values are considered unreliable down to 3460.0 meters (except in a general relative sense) where hole conditions were poor. Cyclicity is noted on the density/neutron curves down to 3512.0 meters due mainly to hole conditions.

3) There is a general compaction effect on the sonic down to 3267.0 meters but the rocks are not normally compacted even at total depth.

4) The density versus sonic " $Z$ " plot shows that crossplotting techniques can prove valuable in discriminating the main bulk lithologies encountered, especially where compaction effects are still apparent on the sonic log.

5) Two distinct logging breaks at $3267.0(373.0 \mathrm{~m})$ and at $3544.0(653.0 \mathrm{~m})$ may indicate some fundamental change in depositional environment. These are not noted in the shipboard summaries.

6) A well-developed interbedded sequence is confirmed by all the logs from 3595.0 to 3613.0 meters which may deserve separate subunit status.

7) Where the caliper is reliable, predictions are more confident.

8) The degree of accord between logs, cores, and the physical properties measurement is good.

9) A gamma-ray recording through drill pipe to sea bed would enable a better depth match with cores and should be adopted as a standard technique.

\section{CORRELATION OF SEISMIC REFLECTORS WITH DRILLING RESULTS}

The control seismic profile through Sites 405 and 406 (Figure 5) was a multichannel seismic profile (line IPOD76-2) made by Seismograph Service (England) Ltd., for the Institute of Oceanographic Sciences (UK) on behalf of the Department of Energy. The multichannel data were acquired using a 2160 in. $^{3}$ airgun array and a 48-channel streamer with 50 meters between traces. The digitized seismic data were resampled at $4 \mathrm{~ms}$ and subjected to true amplitude recovery prior to 24 -fold processing, using de- 


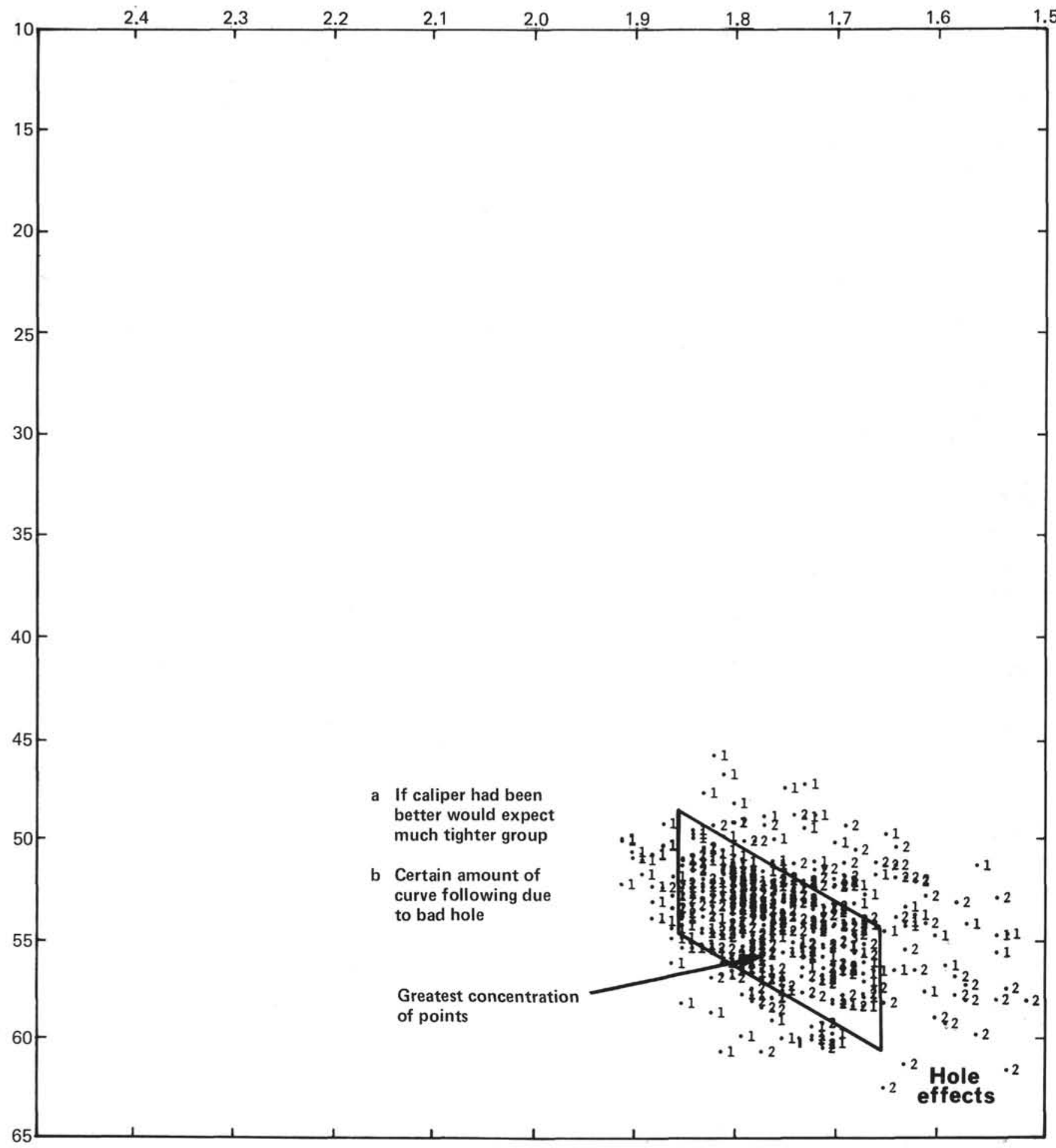

Figure 23. Density versus neutron " $Z$ " plot - gamma-ray relative intensity superimposed $(3125.0$ to $3230.0 \mathrm{~m}, 231.0$ to $336.0 \mathrm{~m}$ ). 


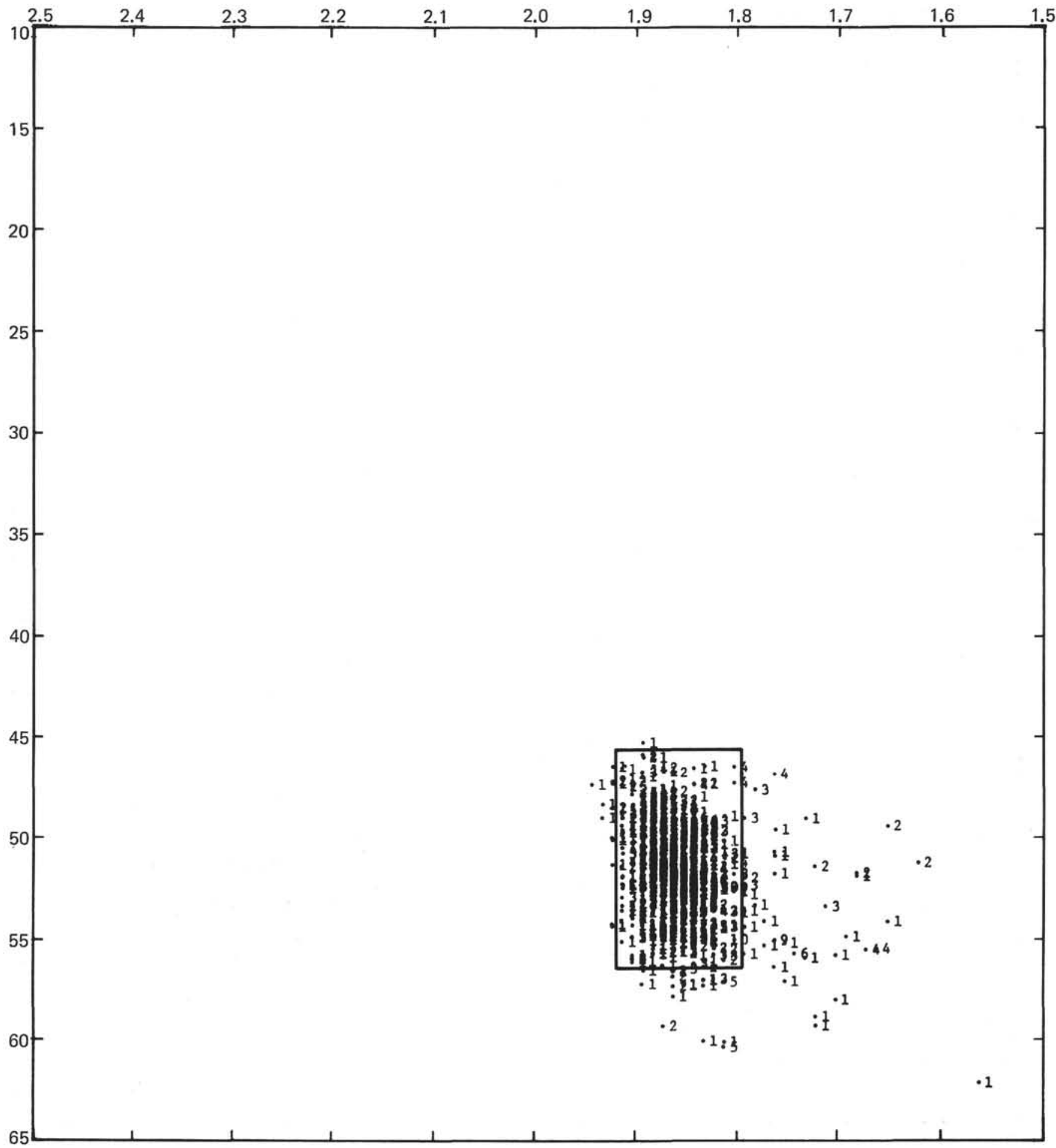

Figure 24. Density versus neutron " $\mathrm{Z}$ " plot - gamma-ray relative intensity superimposed (3230.0 to $3459.0 \mathrm{~m}$, 336.0 to $565.0 \mathrm{~m})$. 


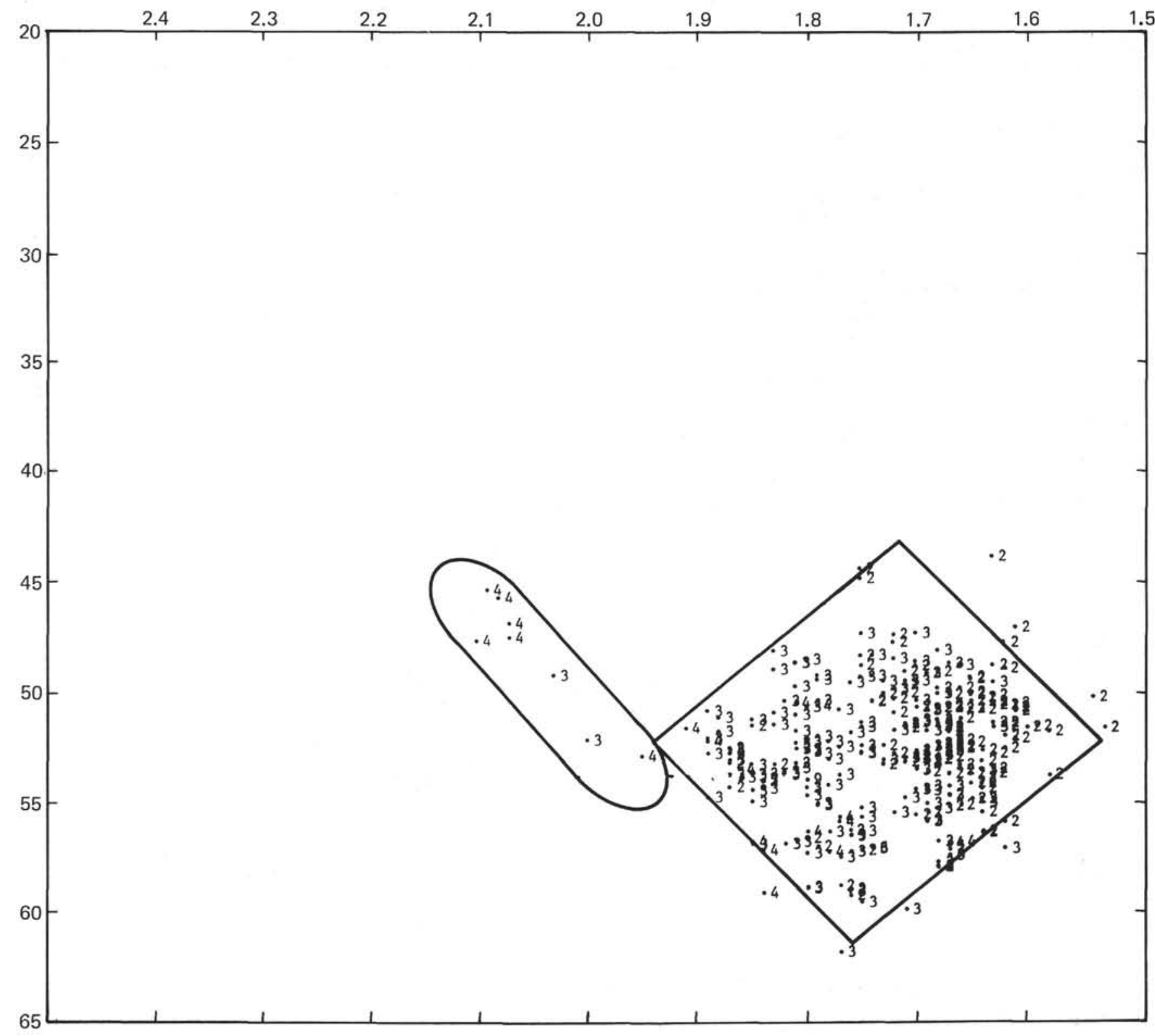

Figure 25. Density versus neutron " $\mathrm{Z}$ " plot - gamma-ray relative intensity superimposed ( 3459.0 to $3545.0 \mathrm{~m}, 565.0$ to $651.0 \mathrm{~m})$. 


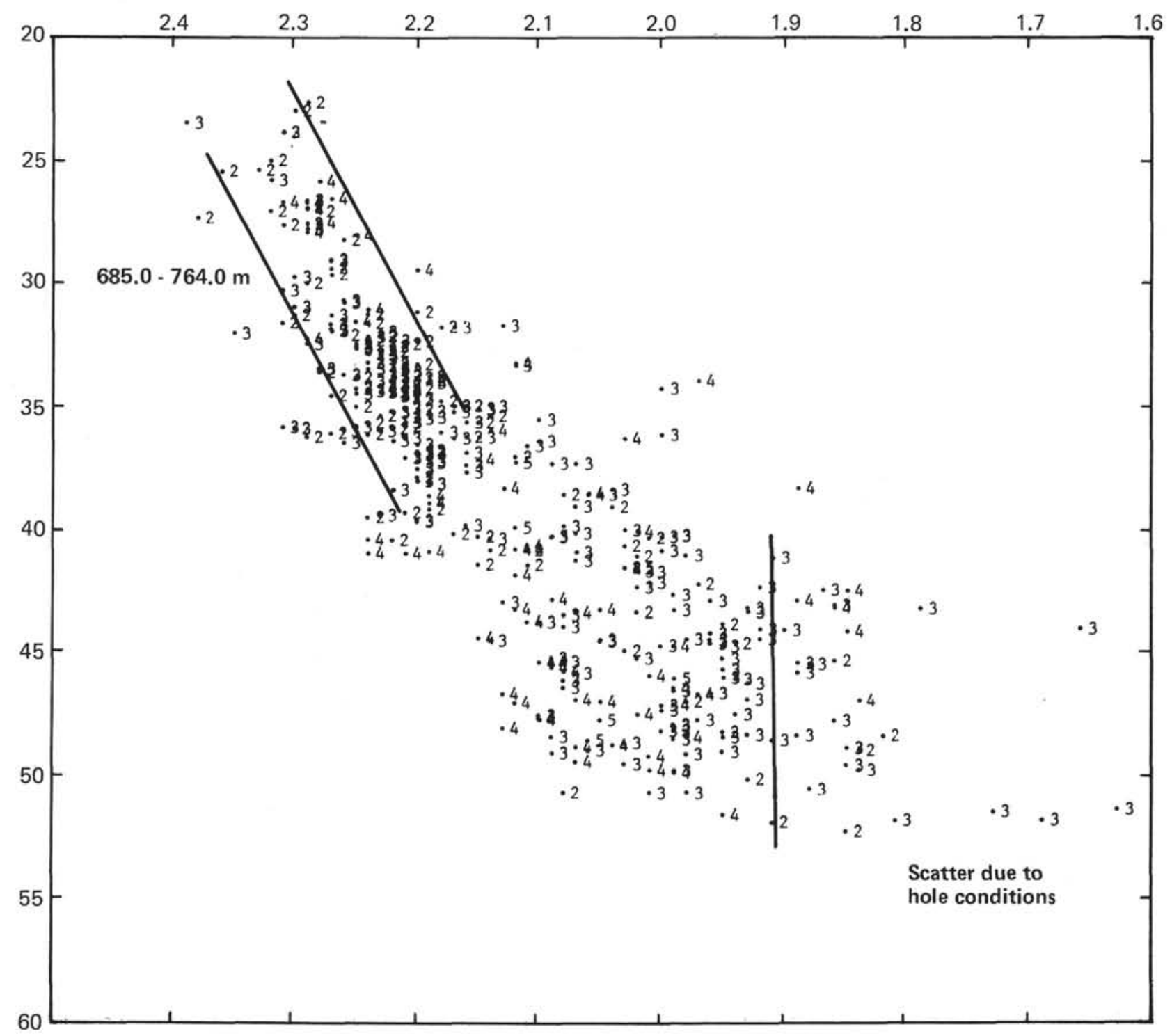

Figure 26. Density versus neutron " $Z$ " plot - gamma-ray relative intensity superimposed $(3545.0$ to $3658.0 \mathrm{~m}, 651.0$ to $764.0 \mathrm{~m}$ ). 


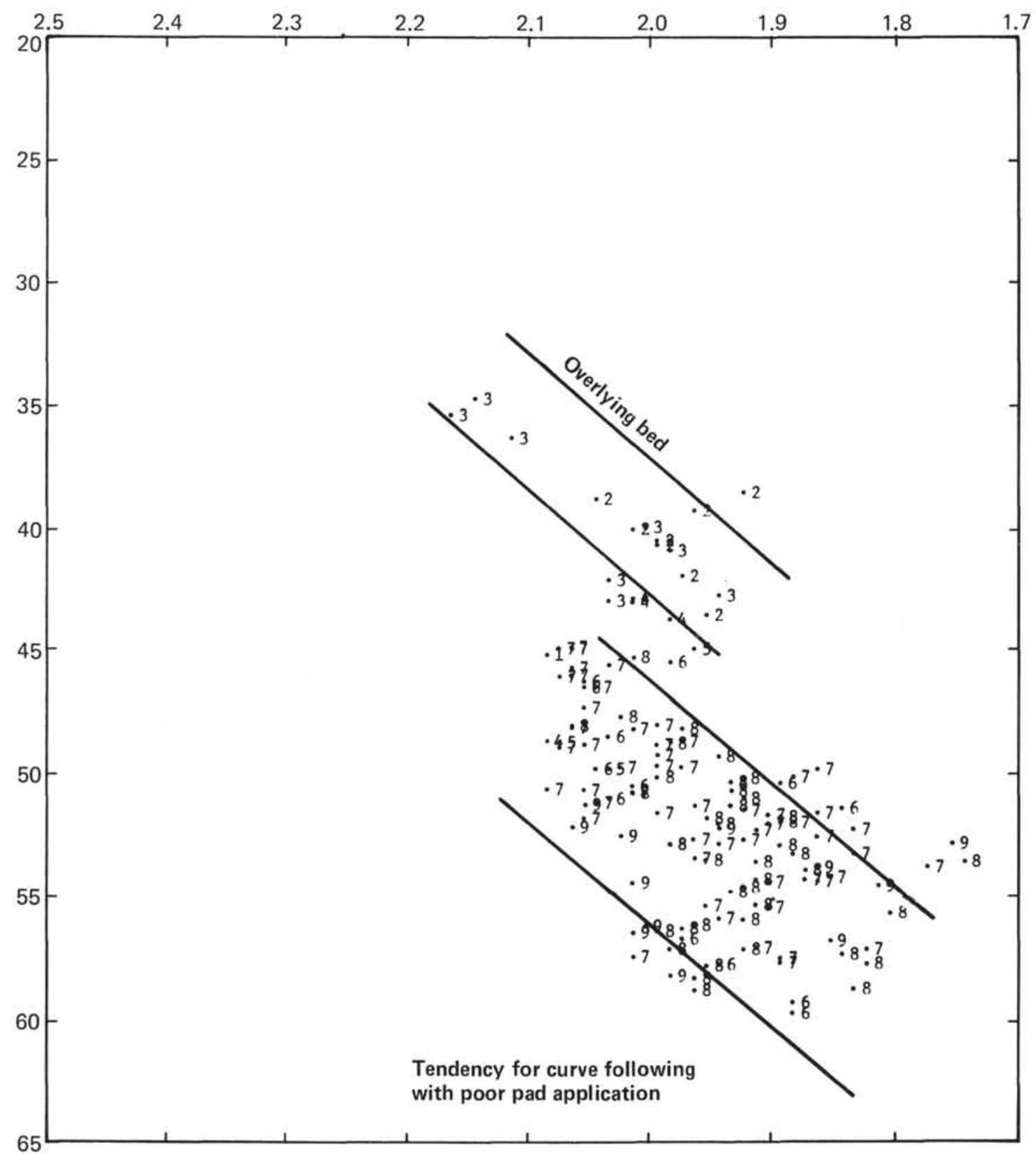

Figure 27. Density versus neutron " $Z$ " plot - gamma-ray relative intensity superimposed (3658.0 to $3702.0 \mathrm{~m}, 764.0$ to $808.0 \mathrm{~m}$ ). 


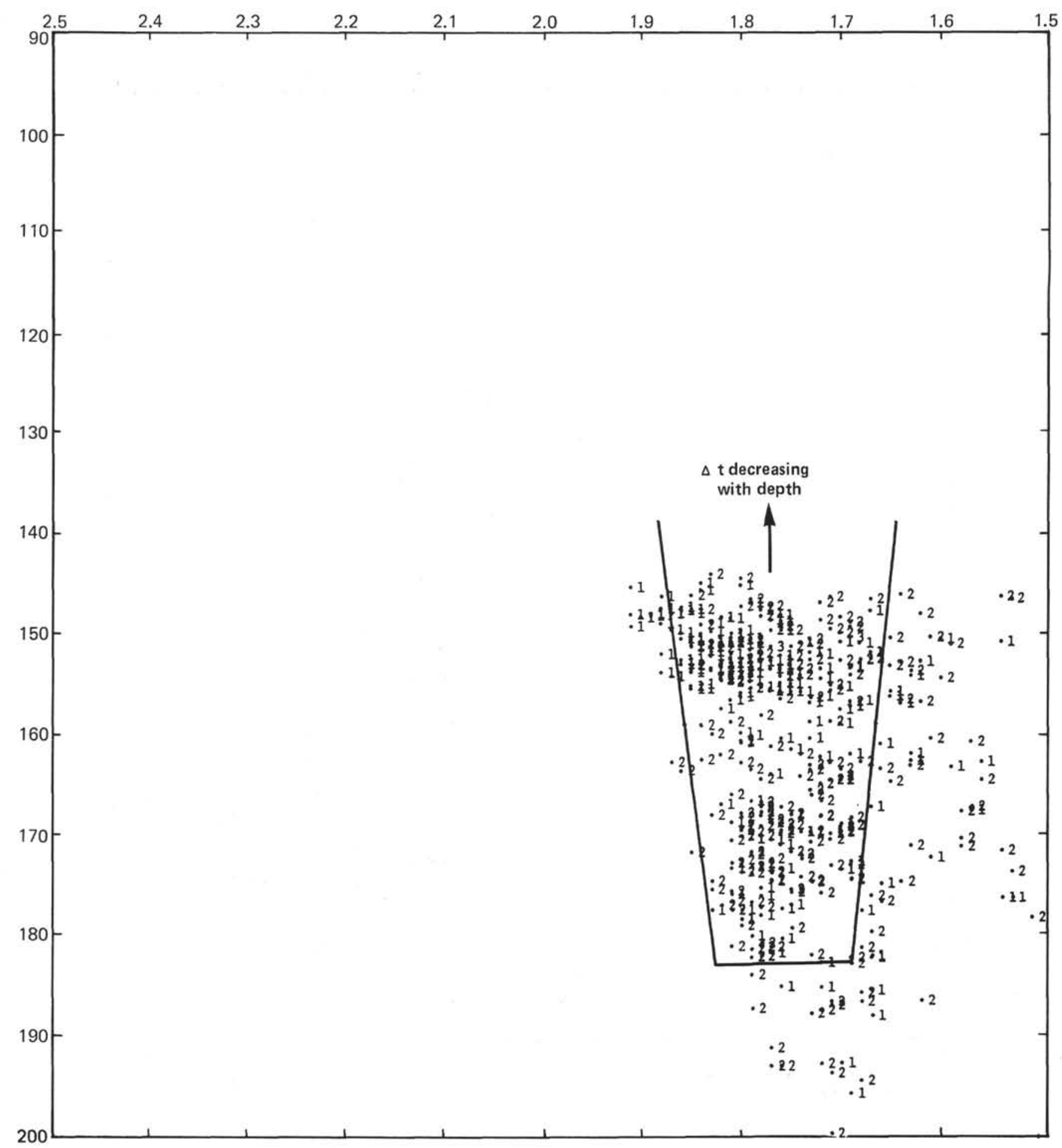

Figure 28. Density versus sonic " $Z$ " plot - gamma-ray relative intensity superimposed ( 3125.0 to $3230.0 \mathrm{~m}, 231.0$ to $336.0 \mathrm{~m})$. 


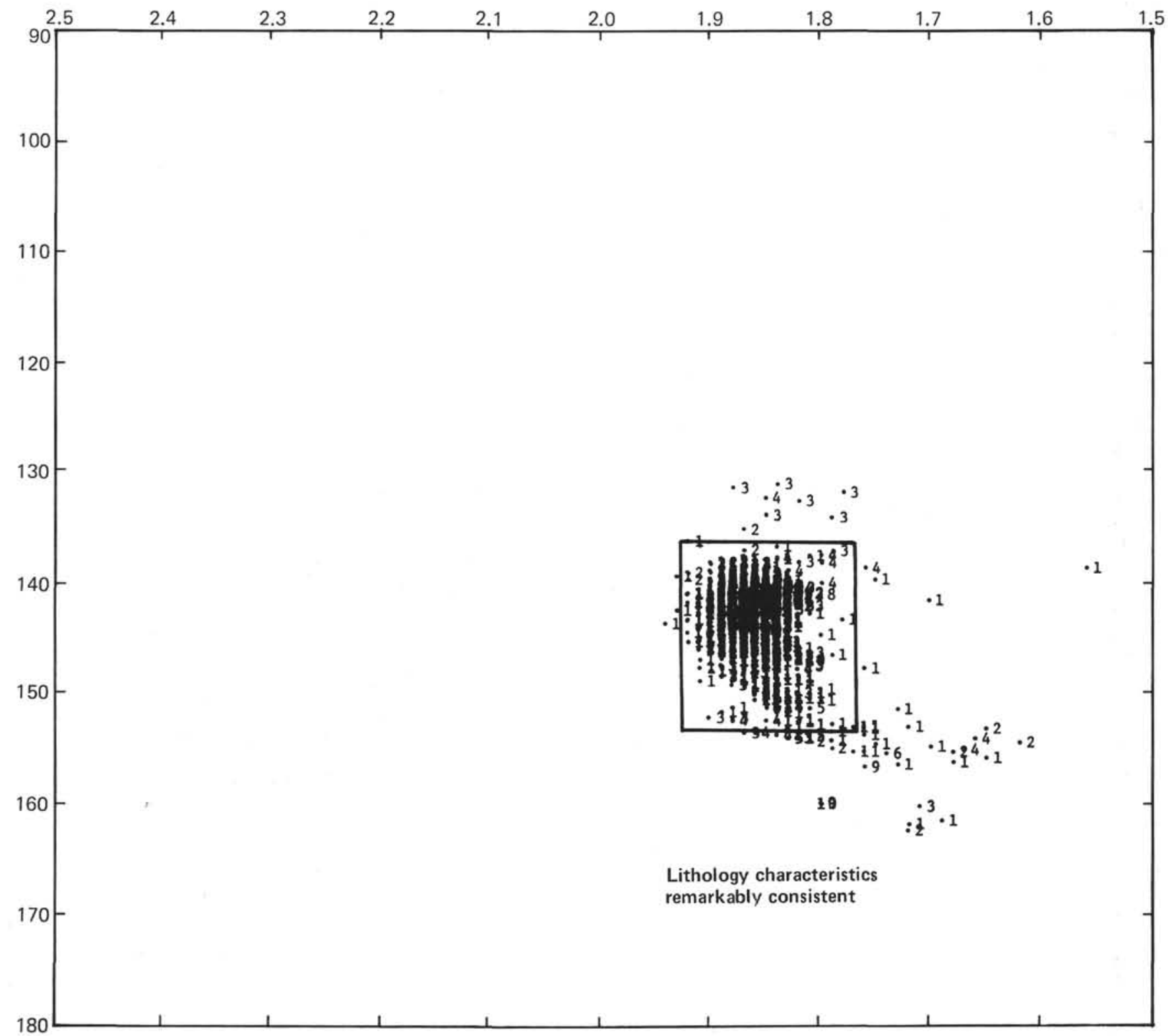

Figure 29. Density versus sonic " $Z$ " plot-gamma-ray relative intensity superimposed ( 3230.0 to $3462.0 \mathrm{~m}, 336.0$ to $568.0 \mathrm{~m}$ ). 


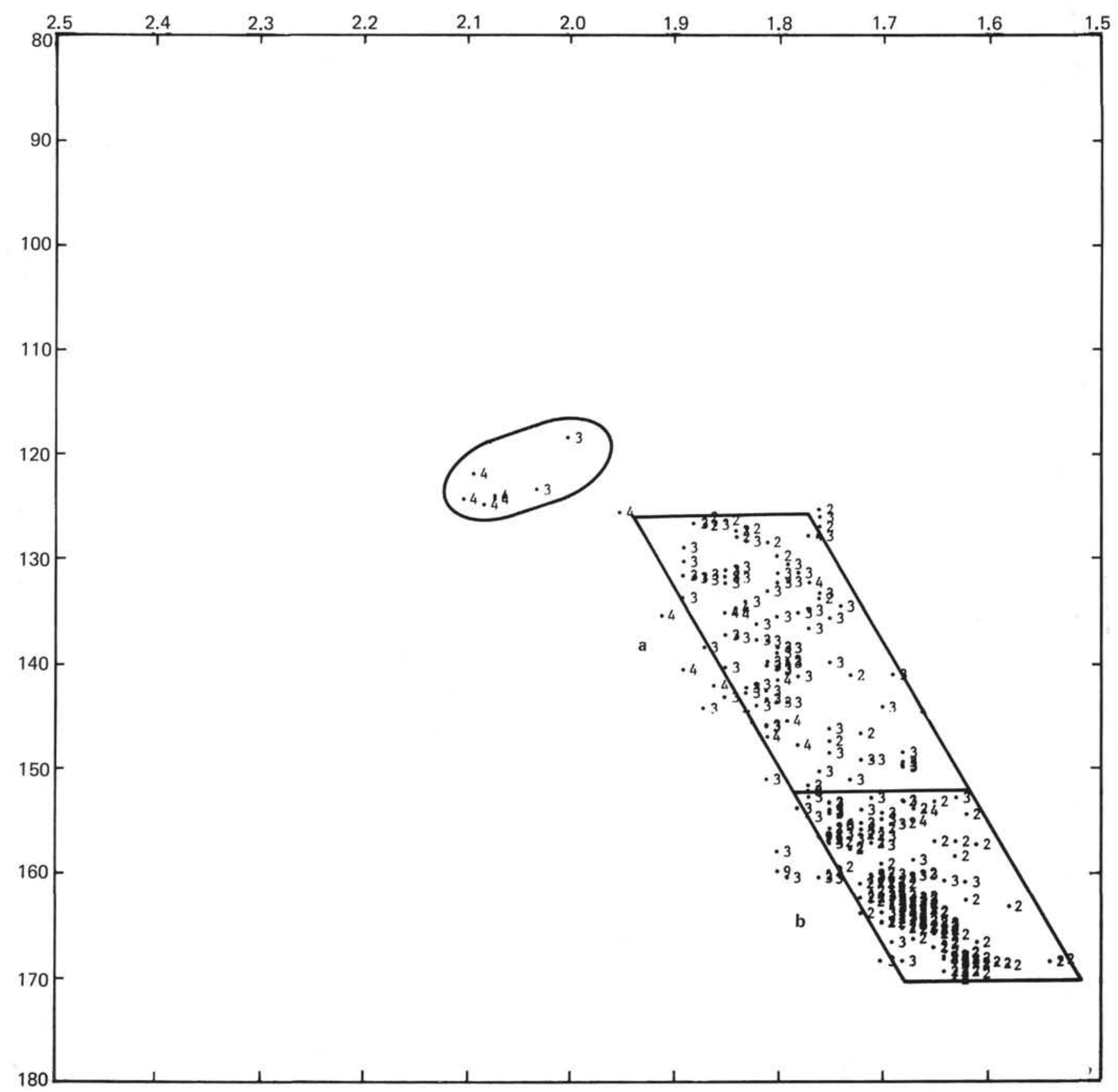

Figure 30. Density versus sonic “ Z" plot-gamma-ray relative intensity superimposed $(3459.0$ to $3546.0 \mathrm{~m}, 565.0$ to $652.0 \mathrm{~m})$. 


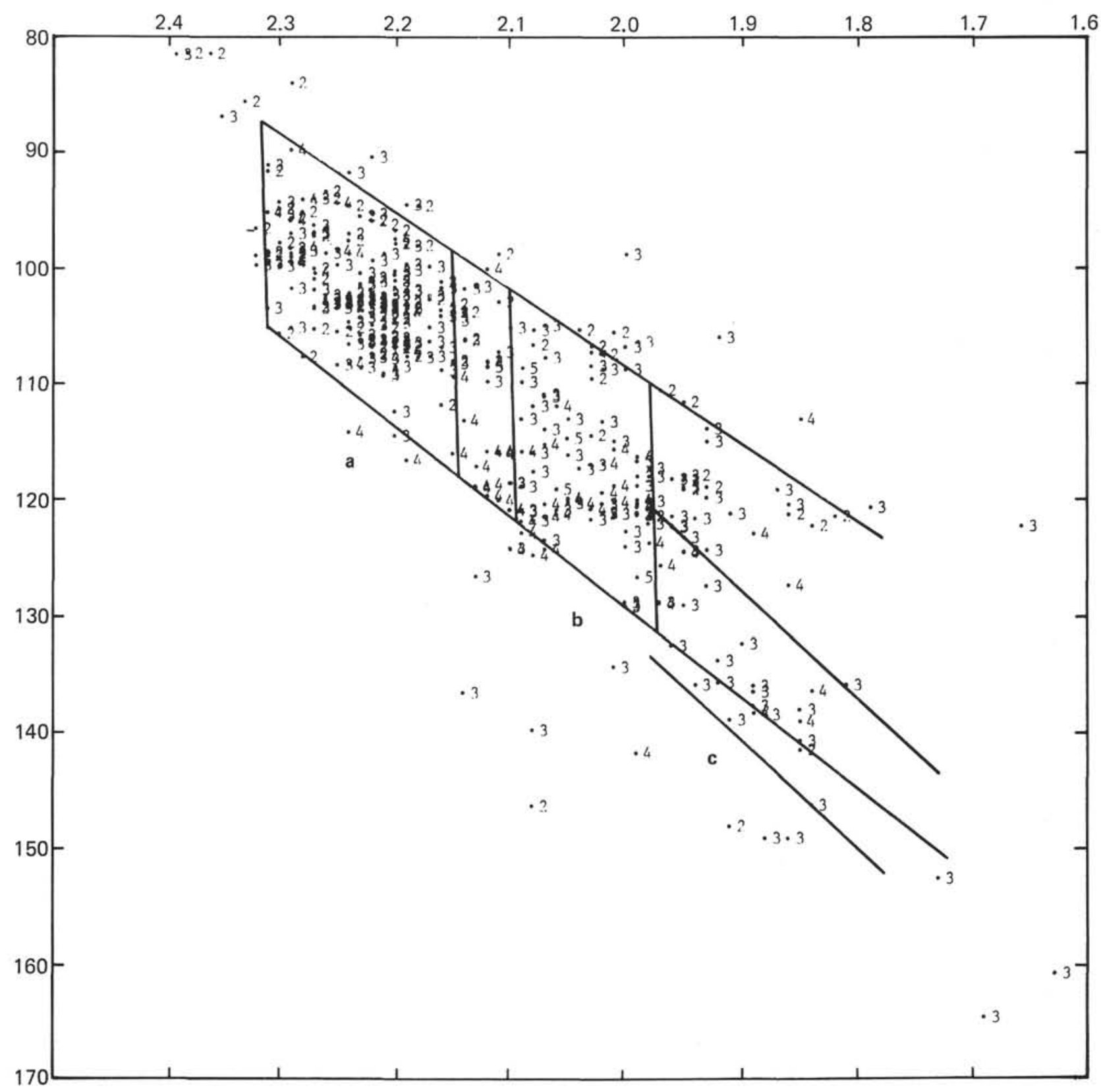

Figure 31. Density versus sonic " $Z$ " plot - gamma-ray relative intensity superimposed (3545.0 to $3658.0 \mathrm{~m}, 651.0$ to $764.0 \mathrm{~m})$. 


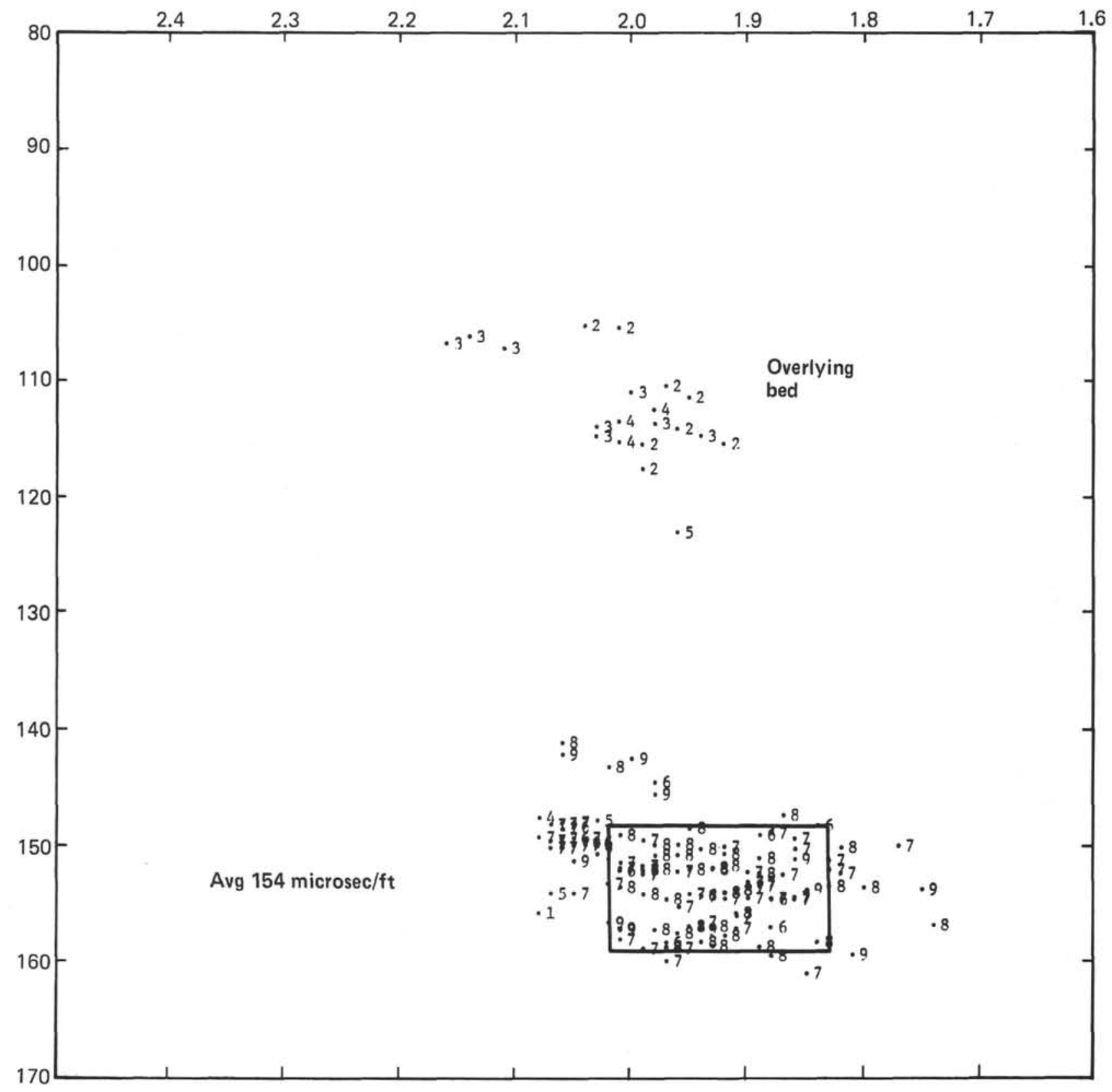

Figure 32. Density versus sonic " $Z$ " plot - gamma-ray relative intensity superimposed $(3658.0$ to $3702.0 \mathrm{~m}, 764.0$ to $808.0 \mathrm{~m}$ ). 


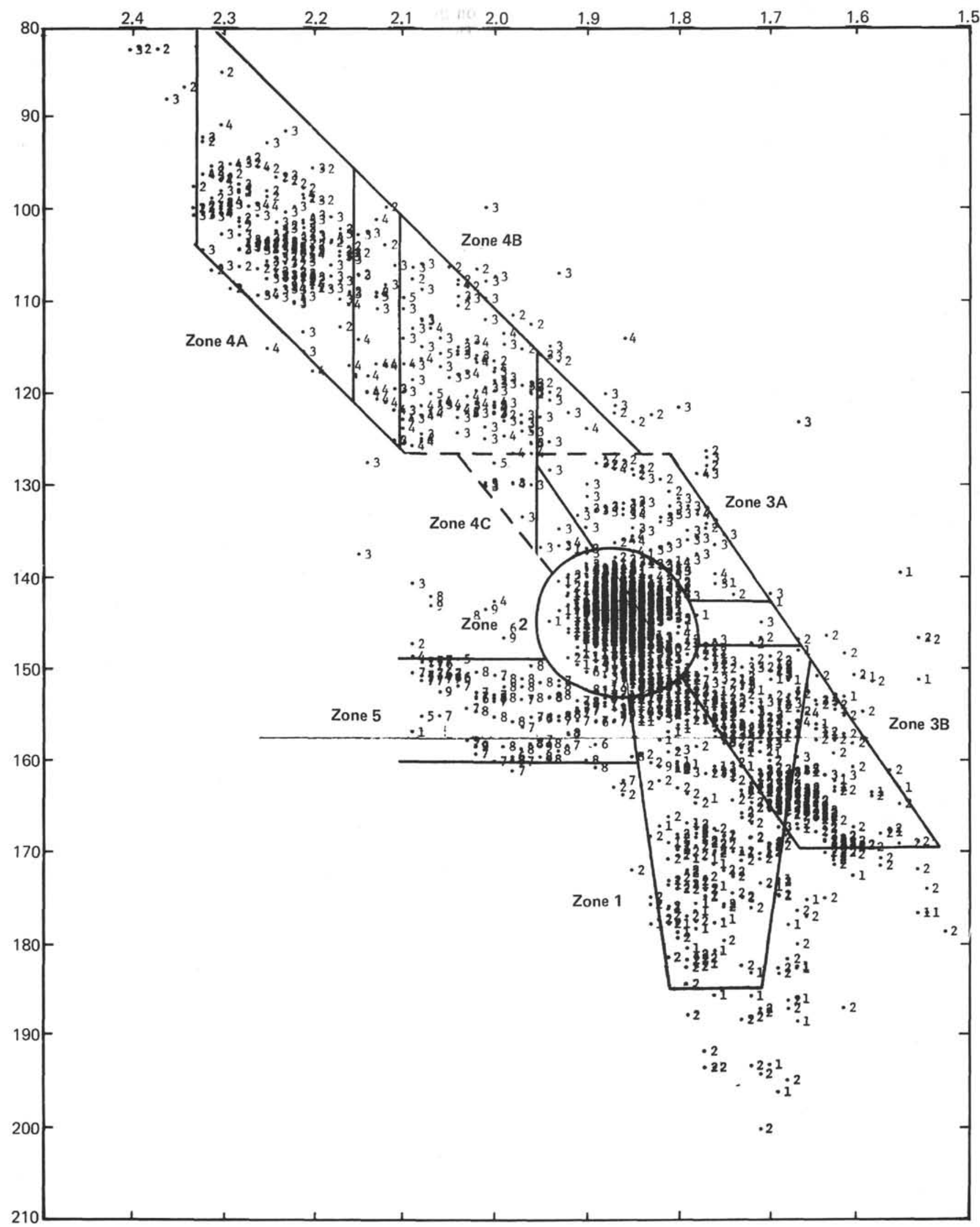

Figure 33. Density versus sonic “ $Z$ ”' composite plot for the depth range 3125.0 to $3702.0 \mathrm{~m}(231.0$ to $808.0 \mathrm{~m})$. 
convolution before and after stack, followed by time varied filtering. The profile has also been reprocessed using diffraction stack migration to clarify reflections in the vicinity of Site 405.

Sites 405 and 406 are located, respectively, at shotpoints 5040 and 4910 , and on the site approach seismic profile at 1250 (29 June 1976) and 1313 (29 June 1976).

The seismic profile is characterized by a thick sediment wedge the top of which is defined by reflector 4 . For convenience, reflectors above the wedge are discussed separately from those below.

Reflector 1, at 0.39 seconds, is a slightly discontinuous reflector exhibiting broad undulations that faintly mirror those of the sea bed. Towards Site 405, reflector 1 is cut out against reflector 2 . Between the sea bed and reflector 1 , the weak and discontinuous reflectors $1 \mathrm{a}$ and $1 \mathrm{~b}$ exhibit cutouts and unconformities suggestive of differential deposition by ocean bottom currents. Beneath the channel adjacent to Site 405 , strong flat-lying reflectors are locally developed in the uppermost 0.2 seconds of section

Reflector 2, at 0.60 seconds, is a strong reflector that rises from the south to overlap the underlying reflectors at shotpoint 4950 . The intra 2-1 section also exhibits features indicative of current-controlled deposition although these are less marked than those above reflector 1 . Between shotpoint 4950 and Site 405, reflector 2 becomes diffuse but apparently rises toward the base of the escarpment.

Reflector 3, at 0.66 seconds, is unconformable with respect to reflector 2 . It does not pinch out against reflector 4 but is the top of a thin interval resting on it. Within the intra 2-3 sequence, a weak reflector, $3 \mathrm{a}$, is present at $0.64 \mathrm{sec}$ onds. The intra 2-3 sequence initially thickens northward but thins as reflector 2 overlaps the underlying reflector 4 .

Reflector 4, at 0.78 seconds, is the top of the distinctive sediment wedge and rises from south to north until overlapped by reflector 2 at shotpoint 4950 . Within the intra 3-4 sequence, the strong reflectors $4 \mathrm{a}$ and $4 \mathrm{~b}$ are cut out northwards against reflector 4 . The underlying sediment wedge is 0.37 seconds thick beneath Site 406 . Reflector $5 a$, within the sediment wedge, marks the onset of a series of reflections the amplitude of which decreases southward. The relationship between reflector 5a and those observed beneath Site 405 is not clear although the latter appear to lie above.

Reflector 5, at 1.13 seconds, is a nearly horizontal, strong, slightly irregular reflector that defines the base of the sediment wedge. It is not the true basement because coherent reflections occur below to a depth of 6.8 seconds. At the fault scarp, the basement rises from 6.8 seconds depth to 3.7 seconds depth in $7 \mathrm{~km}$.

For Site 406, correlation between the seismic reflectors and the lithostratigraphy has been made using synthetic seismograms (Figures 34, 35) generated from the sonic and density downhole logs. The principles of synthetic seismogram generation have been described elsewhere and will not be given again here. The upper 148 meters of the hole were not logged because it was necessary to suspend the drill stem at this depth to support the bumper subs. To construct an accurate velocity model between the sea bed and the top of the sonic log, sonic velocity and density logs were generated by interpolation of the shipboard measurements of these properties made on the few cores taken over this interval. From these data, synthetic seismograms were generated using zero phase bandpass filters approximating 20 and 30 $\mathrm{Hz}$ Ricker wavelets, and time variant filtering. The displays included an acoustic impedance log, primaries plus all order multiples.

The generalized lithology of Site 406 is shown with the electric log data and seismic reflectors in Figure 35 . Weak reflections corresponding to reflectors $1 \mathrm{a}$ and $1 \mathrm{~b}$ are shown on the synthetic seismograms at 0.245 and 0.35 seconds. These reflectors cannot be ascribed to a particular lithology as the equivalent depth intervals were not cored. However, a change in gamma at 195 meters suggests reflector 1a may be associated with an increase in carbonate content. Reflector 1 is predicted at 0.387 seconds $(350 \mathrm{~m})$ in agreement with the observed depth. There is no change in facies at this depth and the reflection may arise from the lithification of ooze to chalk evidenced by the sharp change to more constant sonic velocities and porosities at 350 meters.

Reflector 2 is predicted by the synthetic seismograms at 0.61 seconds $(570 \mathrm{~m})$ in good agreement with the observed depth of 0.60 seconds. The reflector correlates with the change from chalks to calcareous diatomites at the middle/ lower Miocene boundary. The underlying reflector $3 \mathrm{a}$ at 0.64 seconds is apparently associated with a change in diatomite content at the Oligocene/Miocene boundary.

Reflector 3, predicted by the synthetic seismograms at 0.66 seconds $(640 \mathrm{~m})$ marks the change from diatomites with subordinate chalks to calcareous chalks within the Oligocene.

Below reflector 3 , the synthetic seismogram predicts two reflections at 0.72 and 0.74 seconds in good agreement with the observed depths of reflectors $4 \mathrm{a}$ and $4 \mathrm{~b}$. Reflector $4 \mathrm{a}$, at 690 meters, marks the top of an alternating sequence of diatomites and chalks of late Eocene age, whereas reflector $4 \mathrm{~b}$ at 710 meters arises from the change to marly limestones at the base of this sequence.

Reflector 4, predicted by the synthetic seismogram at 0.77 seconds in good agreement with the observed depth, is the unconformity between the upper and the middle Eocene limestones.

In the case of Site 405 , correlation between the diffraction migrated seismic profile and the synthetic seismogram was more problematical. The diffraction migration may have produced a false event earlier in time than the sea bed reflection. Further, poor hole conditions to 240 meters resulted in fluid velocities being logged to this depth. A linear density $\log$ and a sonic velocity log to this depth constructed from the shipboard measurements have been used in addition to the electric logs in computing the synthetic seismograms (Figure 36). At 65 meters below the sea bed, the major hiatus between the lower Pliocene and the middle Eocene is considered to mark reflector 4 and thus the top of the sediment wedge. Below this depth, the significance of the correlation between the synthetic seismogram and the seismic reflection profile is less apparent. The three reflectors (Figure 37 ) appear to correlate with variations in the silicification of the lower Eocene calcareous mudstones.

The relationship between the stratigraphy and reflectors at Sites 405 and 406 is summarized in Figures 35 and 37. 
FILTERING PARAMETERS

\begin{tabular}{|c|c|c|}
\hline ZERO PHASE BANDPASS & ZERO PHASE BANDPASS & A TIME VARIANT BANDPASS FILTER \\
\hline FILTER APPROXIMATING A & FILTER APPROXIMATING A & $50-55 \mathrm{~Hz}$ \\
\hline $20 \mathrm{~Hz}$ RICKER WAVELET & $30 \mathrm{~Hz}$ RICKER WAVELET & $40-44 \mathrm{~Hz}$ \\
\hline
\end{tabular}

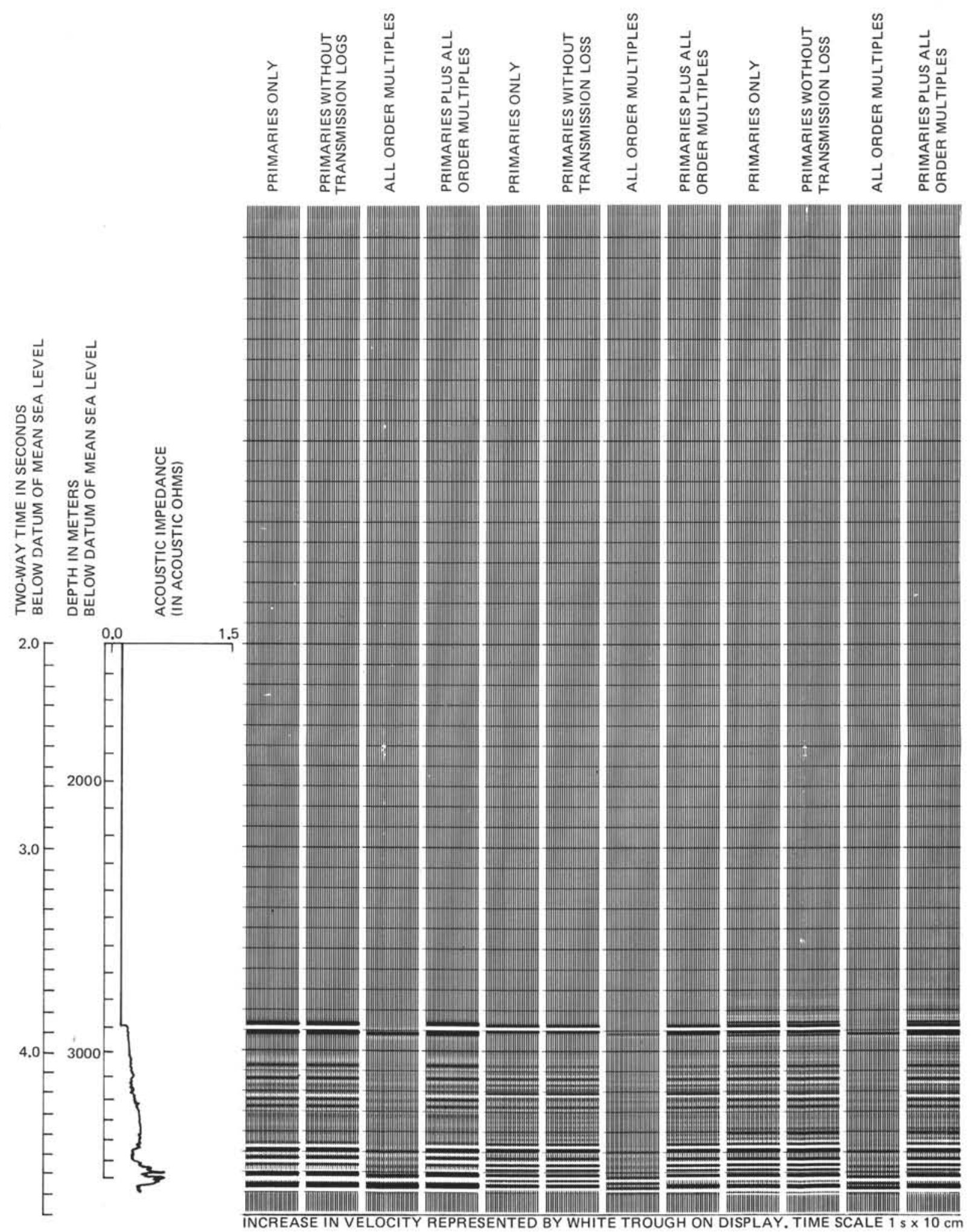

Figure 34. Synthetic seismogram for Site 406. 


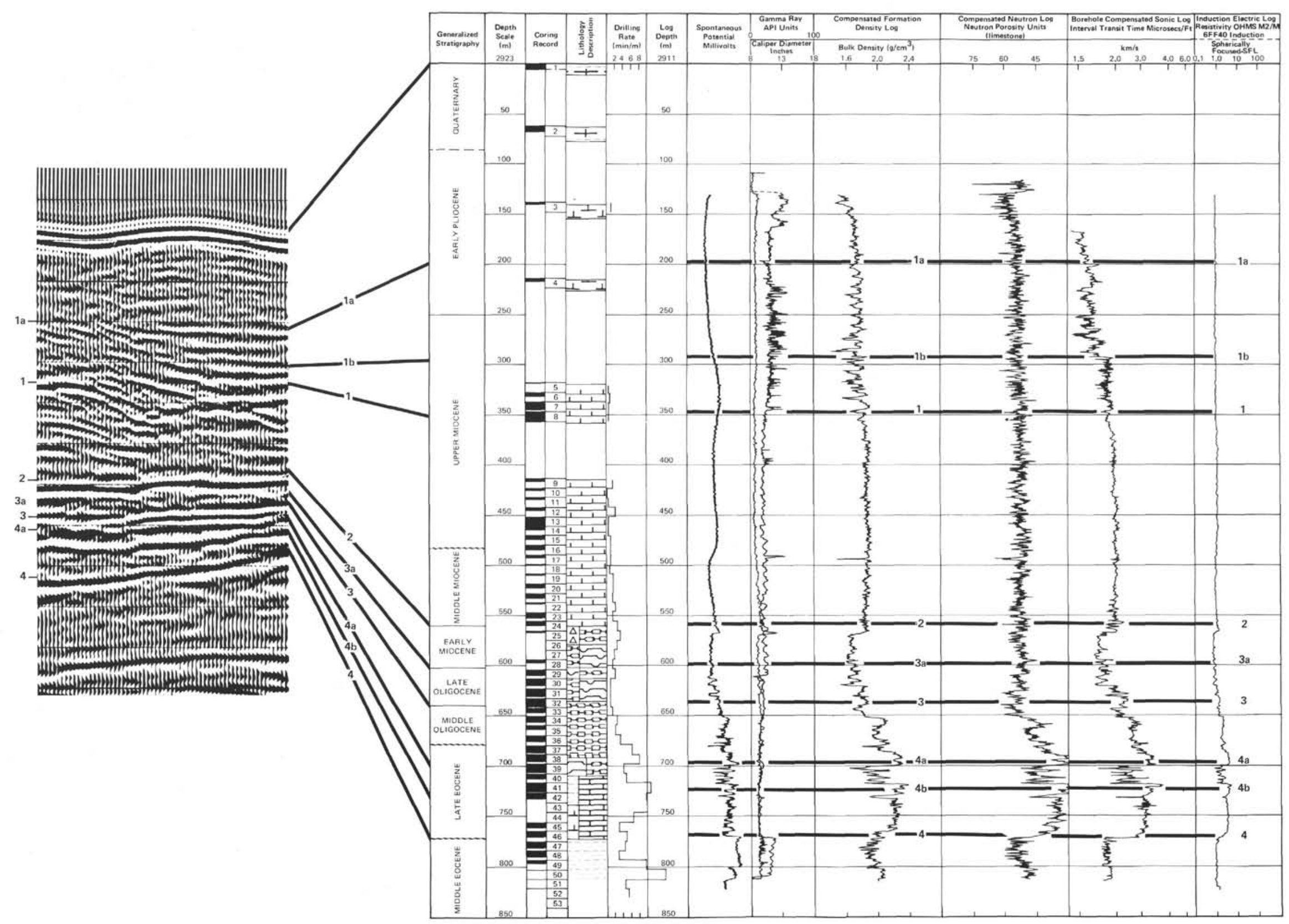

Figure 35. Correlation of seismic reflectors at Site 406. 
FILTERING PAPARMETERS

ZERO PHASE BANDPASS FILTER APPROXIMATING A $20 \mathrm{~Hz}$ RICKER WAVELET
ZERO PHASE BANDPASS FILTER APPROXIMATING A

$30 \mathrm{HZ}$ RICKER WAVELET
A TIME VARIANT BANDPASS FILTER

7-10 $50.55 \mathrm{~Hz}$ At 3.9 s

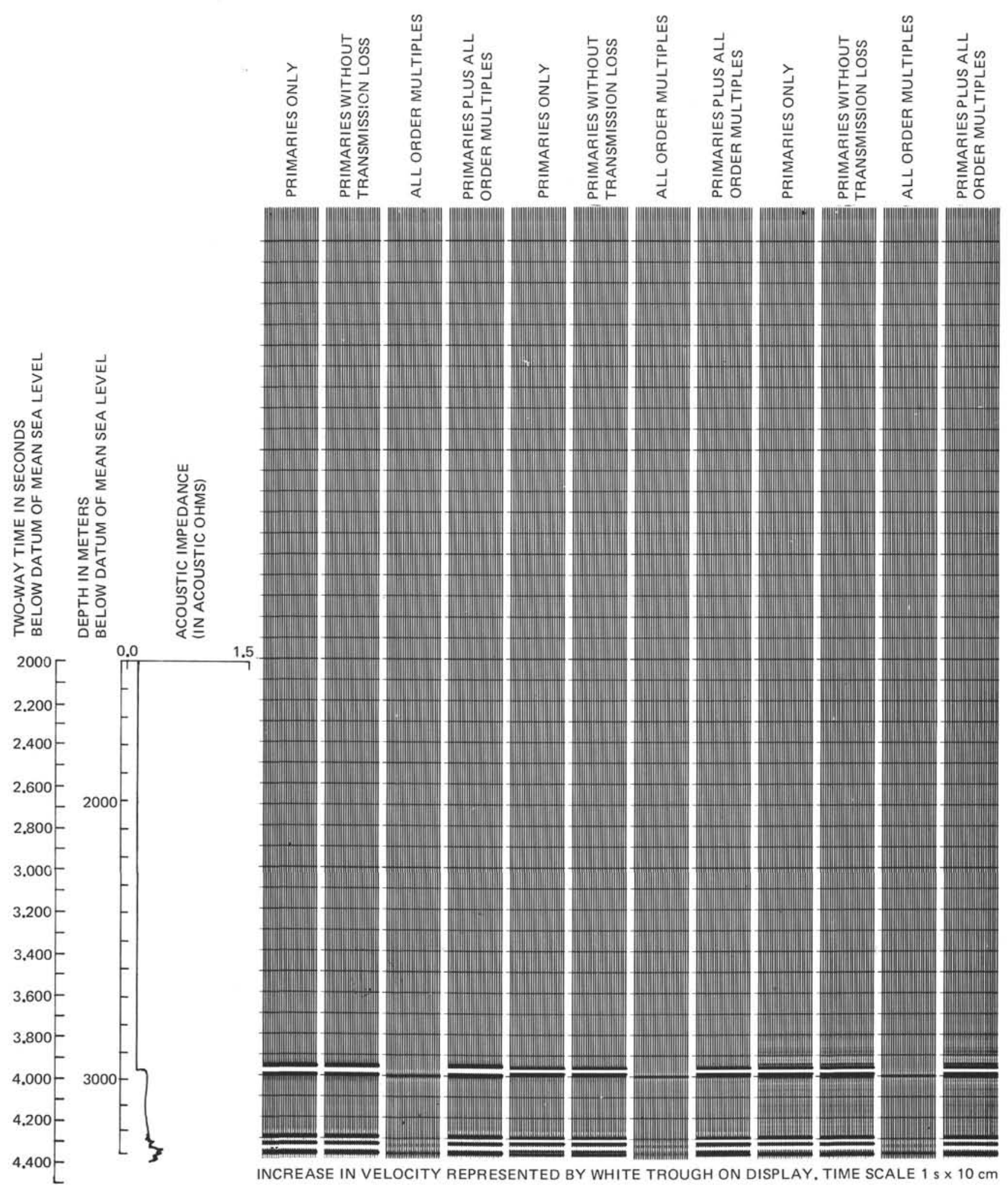

Figure 36. Synthetic seismogram for Site 405. 


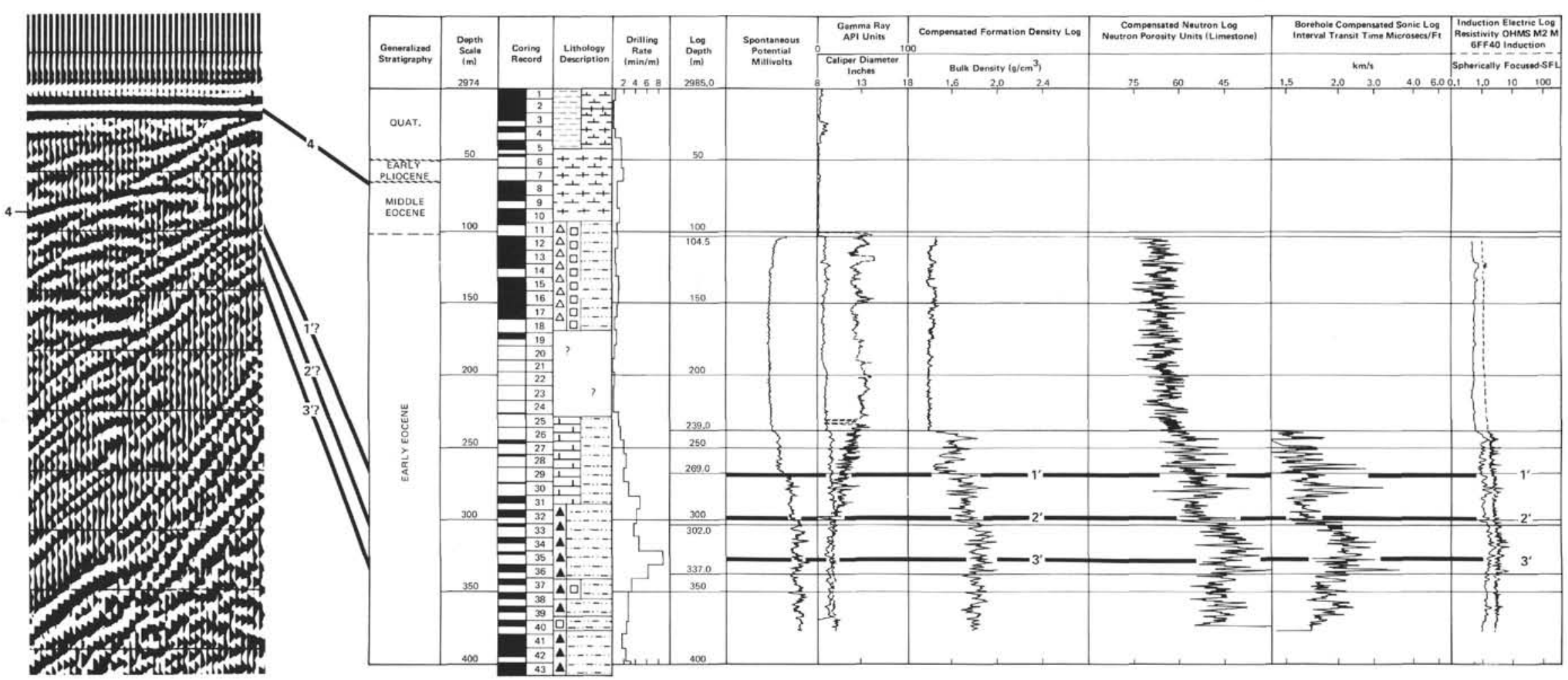

Figure 37. Correlation of seismic reflector at Site 405. 


\section{SEDIMENTATION RATES}

\section{Site 405}

At Site 405 , a sedimentary wedge, more deeply buried to the south, lies close to the sea bottom. Rates of sedimentation at the site are based mainly on nannofossils because precise age determinations were not possible using foraminifers (Figure 38).

For the Pleistocene section of 46 meters recovered in Cores 5 to 7 , a sedimentation rate of about $24 \mathrm{~m} / \mathrm{m}$.y. is calculated. The Pliocene is missing except for the lowermost part (NN 12 to N.18), and the hiatus between the Pleistocene and lowermost Pliocene represents an interval of about $2.6 \mathrm{~m} . \mathrm{y}$. The upper Miocene (NN 11 to N.17) of Core 7 is underlain by middle Eocene sediments (NP 14) and by lower Eocene sediments (NP 13, NP 12); this hiatus represents an interval of at least $40 \mathrm{~m} . \mathrm{y}$.

The lower-middle Eocene sequence, deposited during an interval of $3 \mathrm{~m} . \mathrm{y}$. has the enormous thickness of 342.0 meters, giving a sedimentation rate of $114 \mathrm{~m} / \mathrm{m} . \mathrm{y}$. The upper part of this sequence is rich in siliceous microfossils, which are missing in the lower part.

The sedimentation rate curve established for this hole can be explained by the particular geological setting of the location. Lower Eocene sediments accumulated as a thick wedge along the faulted margin of the Rockall Plateau. They thin rapidly southward where they are covered by a thick post-lower Eocene section. The pinch-out of the cover near Site 405 explains the discontinuous and thin upper section recovered there.

\section{Site 406}

Site 406 , located about 5 miles south of Site 405 in a more basinal position, displays a thick sequence of Quaternary (NN 21 to N.23) to upper Miocene (NN 11/10 to N.16) sediments, from Core 1 to Core $15(0-480.0 \mathrm{~m})$. The upper part of this sequence was only spot cored. In the sedimentation rate curve (Figure 39), no break is recognized, and for this time interval, the rate is calculated at about $45 \mathrm{~m} / \mathrm{m}$.y. The upper Miocene is underlain disconformably by middle Miocene sediments (NN 6 to N.12); the hiatus represents an interval of about $3 \mathrm{~m}$.y. For the lower part of the middle Miocene and the uppermost part of the lower Miocene, the sedimentation rate is calculated at about $34 \mathrm{~m} / \mathrm{m}$.y. Only the lowermost Miocene is present. The hiatus within the lower Miocene sequence encompasses an interval of about $6 \mathrm{~m}$.y. The lower Miocene to middle Oligocene section occurring in Cores 25 to 36 , Section $1(565.5-671.0 \mathrm{~m})$ indicates a sedimentation rate of about $22 \mathrm{~m} / \mathrm{m}$.y

A hiatus of about $8 \mathrm{~m}$.y. includes the interval between the middle Oligocene (NP 24 to N.1 to N.3) and the upper Eocene (NP 19/NP 20 to P.18 to P.14). For the upper Eocene sequence of 90 meters, a sedimentation rate of about $30 \mathrm{~m} / \mathrm{m}$.y. is calculated. For the underlying middle Eocene (NP 14 to P.8 to P.13), the rate is about $70 \mathrm{~m} / \mathrm{m} . y$., and the hiatus between the upper and middle Eocene marks an interval of about 8.2 m.y.

\section{SUMMARY AND CONCLUSIONS}

Sites 405 and 406 were situated on and to the south of the prominent east-west scarp that forms part of the rectilinear southwest margin of the Rockall Plateau. Site 405, drilled in 2958 meters water depth, bottomed at 407.0 meters in claystones of early Eocene age. Site 406, drilled approximately 5 miles to the south, bottomed at 822 meters in marly limestones of middle Eocene age.

The east-west segment of the southwest margin may have been a transform fault with an offset of 100 miles active between 73 and 55 m.y., during the early opening of the Labrador Sea (Olivet et al., this volume; Roberts, 1974, 1975; Roberts et al., this volume). Motion along the transform fault may have been partly contemporaneous with the rifting that initially structured the younger northeastsouthwest margin drilled at Sites 403 and 404.

Sites 405 and 406 were sited on the transform fault using a 24-fold 48-trace seismic profile made by the Institute of Oceanographic Sciences. The seismic section (Figure 40) shows a prominent basement fault scarp with a relief of about 3.5 seconds (two-way time). At the foot of the scarp, presumed continental basement lies at about 0.5 seconds depth in contrast to the oceanic basement to the south at 4.0 second depth. Within the overlying section, five prominent reflectors are present. A strong flat-lying reflector (5) at about 1.0 second depth is underlain by a series of strong flat-lying reflectors that infill the irregular oceanic basement. Above reflector 5, a prominent fan-like sedimentary wedge defined by reflector 4 , thickens northward to the base of the scarp. Reflectors 1, 2, and 3 pinch-out northward against reflector 4 .

Site 406 was located at the southern edge of the channel aligned along the base of the fault scarp and was designed to penetrate to reflector 5 through the outer part of the fan-like body. Site 405 was situated at the southern edge of the fault scarp and was intended to penetrate through the lower part of the fan. Collectively the sites were drilled to provide a composite stratigraphic section to reflector 5 .

\section{Site $\mathbf{4 0 5}$}

Site 405 was continuously cored from the sea bed at 2974 meters to a total sub-bottom depth of 407 meters. Almost the whole of the Pliocene (ca. 3 m.y.) is unrepresented, and a hiatus of about $43 \mathrm{~m}$.y. was present between the upper Miocene and the middle Eocene.

Two main lithologic units and six sub-units were recognized in the section. Unit 1 extends from the sea floor to the prominent upper Miocene/middle Eocene hiatus at a depth of 65 meters. The hiatus is considered to correspond to reflector 4. Sub-unit $1 \mathrm{~A}$ consists principally of yellowish brown marly foraminifer nannofossil ooze and greenish gray foraminifer nannofossil ooze. The characteristic mineral assemblage consists of illite (40\%), smectite $(20-40 \%)$, chlorite $(15 \%)$, kaolinite $(10 \%)$, and calcite (mean $40 \%$ ). Pebbles of presumed ice-rafted origin occur throughout the sub-unit. In contrast, Sub-unit $1 \mathrm{~B}$ is characterized by high carbonate $(90 \%)$, smectite $(40 \%)$, 


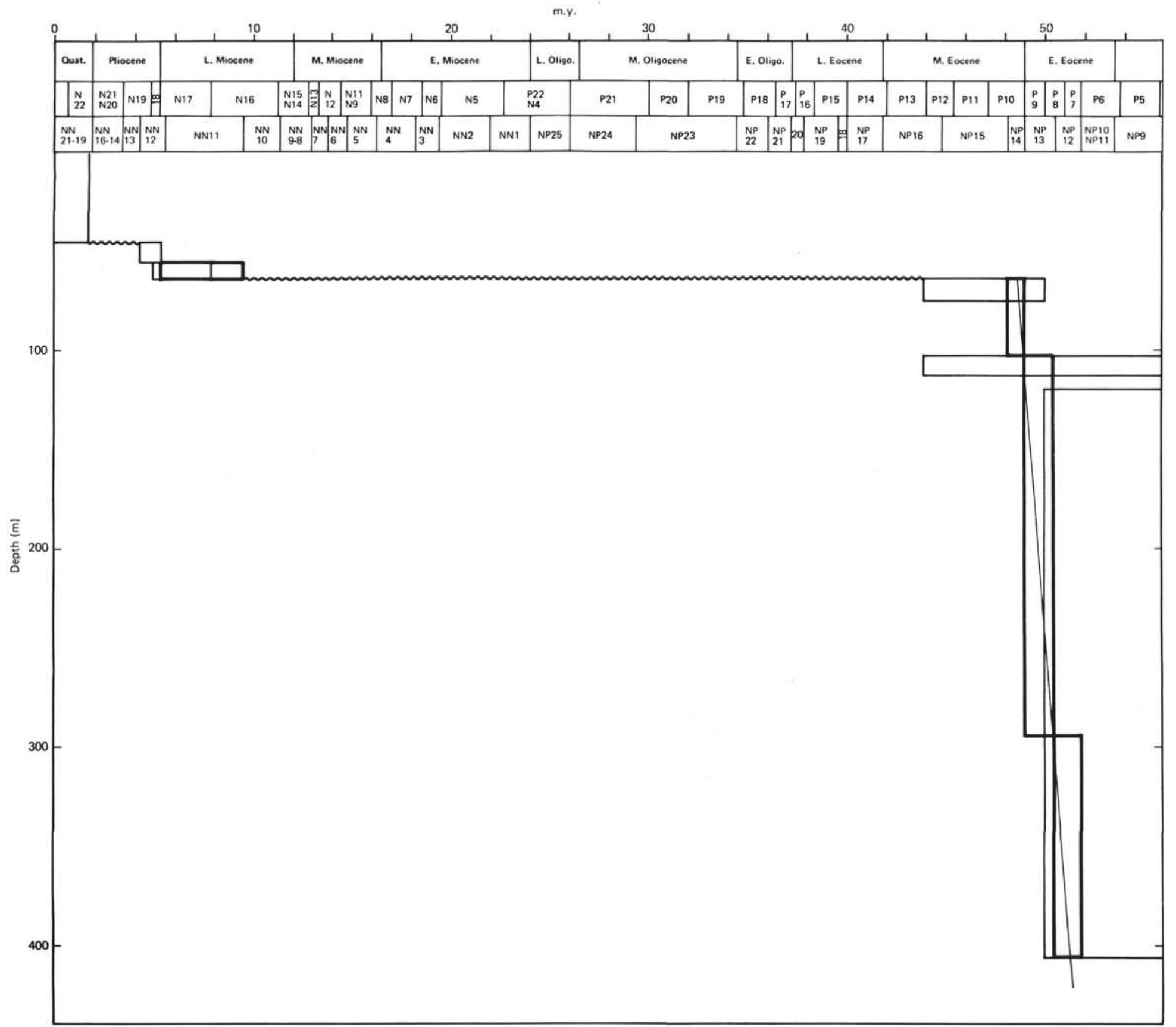

Figure 38. Sedimentation rates, Site 405. 
illite $(40 \%)$, with minor kaolinite and chlorite; detrital quartz and feldspar are absent.

The boundary between Units 1 and 2 is defined by the middle Eocene/upper Miocene hiatus and is also characterized by a change to a mineralogical assemblage consisting of low carbonate, smectite with high crystallinity, and dominant silica (opal-CT or amorphous) (Latouche and Maillet, this volume). Four sub-units have been defined on the basis of carbonate content, degree of bioturbation, and silicification.

Sub-unit $2 \mathrm{~A}$ is of middle Eocene age and is paleontologically correlative with Cores 49 to 52 of Site 406 . The principal lithologies are foraminifer nannofossil ooze, nannofossil ooze, and siliceous nannofossil ooze. Carbonate decreases throughout the sub-unit from 70 to 30 per cent. The benthic foraminiferal assemblage of Core 8 is believed to indicate epibathyal conditions $(\sim 1000 \mathrm{~m})$. Sub-unit 2B $(100-245 \mathrm{~m})$ consists of olive-gray to dark greenish gray siliceous mudstone and is characterized by abundant biogenous silica $(20-30 \%)$. The variation in palynological assemblages in different samples may suggest variable ocean currents. Reworked Senonian dinocysts are rare (Costa and Downie, this volume). Sub-unit 2C (245-300 m) is composed of calcareous mudstone in which detrital clay is dominant and biogenous silica absent. Burrows are flattened parallel to the bedding and plane laminae and dips of up to 10 degrees are present. Glauconite is present in some laminae and burrows. Sub-unit 2D (300-407 m) comprises dark greenish gray silicified mudstone with occasional chert layers. A higher proportion of authigenic silica is present. Common laminae show dips ranging from 15 to 20 degrees near the base. A $2-\mathrm{cm}$ bed of tuffaceous material was observed in Core 43 (Zone NP 12, cf. Site 403). Palynological assemblages from Sections 43-1 and 43-6 suggest nearby fluctuating shelf environments giving way to shallow tropical embayments (Costa and Downie, this volume). The planktonic foraminifer assemblages of Cores $8-43$ are characterized by small size low diversity and the presence of intergradational species. Benthic foraminifer assemblages are a mixture of bathyal and upper-slope to shelf species suggesting frequent contamination (Murray, this volume).

\section{Site 406}

The 822-meter section penetrated at Site 406 includes sediments ranging in age from Quaternary to middle Eocene. Hiatuses in the section occur between the upper and middle Miocene, possibly within the lower Miocene, between the middle Oligocene and the upper Eocene, and between the upper Eocene and the middle Eocene. Five lithologic units and three sub-units have been recognized.

Unit $1(0-65.0 \mathrm{~m})$ consists of olive-gray calcareous mud, light olive-gray marly foraminifer nannofossil ooze, and gray foraminifer nannofossil ooze occurring in rhythmic alternations. Occasional ice-rafted pebbles are present and the clay mineral assemblage consists of illite $(40 \%)$, smectite $(25 \%)$, chlorite $(18 \%)$, and kaolinite $(15 \%)$ (Latouche and Maillet, this volume). Benthic foraminifers are lower bathyal to abyssal (Murray, this volume). Unit 2 (110-557.5 m), Pliocene to middle Miocene, comprises bluish white to light greenish gray foraminifer nannofossil ooze and chalk and is characterized by a uniformly high carbonate content (avg. 90\%). The clay fraction is dominated by smectite but a component of illite, kaolinite, and chlorite is present throughout. Fine, parallel wavy and contorted laminae are characteristic. In the lower 10 to 20 $\mathrm{cm}$, a color change to the greenish yellowish gray of Unit 3 is also marked by an increase in biogenic siliceous components, a decrease in carbonate, and the disappearance of illite, chlorite, and kaolinite. Benthic foraminifers indicate a lower bathyal to abyssal environment (Murray, this volume). Although no facies change occurs within the unit, reflector 1 may arise from the lithification of ooze to chalk at 350 meters shown by the sharp change in physical properties and the logs.

Unit 3 (557.5-617.5 m) ranges in age from early Miocene to late Oligocene and consists principally of diatomaceous chalk with interbeds of calcareous diatomite often with paper-thin lamination. Diatoms $(40-60 \%)$, carbonate (30$40 \%)$, and smectite $(10-20 \%)$ are the principal components with minor radiolarians and sponge spicules. Reflector 2 correlates with the change from chalks to calcareous diatomites at the middle Miocene/lower Miocene boundary. Underlying reflector 3 a correlates with a change in diatomite content at the Oligocene/Miocene boundary. Reworked Eocene palynomorphs are common and the upper Oligocene palynological assemblage has a close affinity with those of the Norwegian Sea (Costa and Downie, this volume).

Unit $4(617.5-765.0 \mathrm{~m})$ is divided into three sub-units based on the presence or absence of slump structures and the relative abundance of biogenic silica. Its top is defined by the middle Oligocene/upper Eocene hiatus. Sub-unit 4A (617.5-671.5 m) consists dominantly of light greenish gray to pale green calcareous chalk interbedded with bioturbated siliceous calcareous chalk and foraminifer nannofossil chalk at a centimetric scale. In contrast to Unit 3, biogenic siliceous components comprise only 8 per cent, but the carbonate content is 78 per cent. Traces of glauconite occur in Cores 33 and 34 (middle Oligocene, cf. Site 403). Reworked Senonian and Eocene palynomorphs are common. Sub-unit 4B $(671.5-708 \mathrm{~m})$ is distinguished by the presence of slumping and a more abundant biogenic silica component of 12 per cent. Slumps found in Cores 37 (1-2) and 37 (2-3-4) are, on the average, less than 1 meter thick associated with microfaulting, microslumps, and "varve-like" laminae. Abundant middle to upper Eocene foraminifer fragments are present in Core 37. Reflector $4 \mathrm{a}$ at 690 meters marks the top of the alternating sequence of upper Eocene diatomites and chalks where reflector $4 \mathrm{~b}$ arises from the change to marly limestones at the base. Sub-unit $4 \mathrm{C}$ consists of limestone and nannofossil limestone, characterized by minor biogenic siliceous components and abundant carbonate (avg. 80\%). Slumped beds occur in Cores 41,42 , and 45 . In one slump, upper Eocene limestone is overlain by a conglomerate containing fragments of mudstone of early Eocene age in a matrix of upper Eocene calcareous chalk. Within the unit, reworked Upper Cretaceous and lower Eocene dinocysts are common (Costa and Downie, this volume). The benthic foraminiferal assemblage of Core 41 indicates deposition in epibathyal depths (Murray, this volume). The base of Unit 4 is defined by the unconformity between the 
న

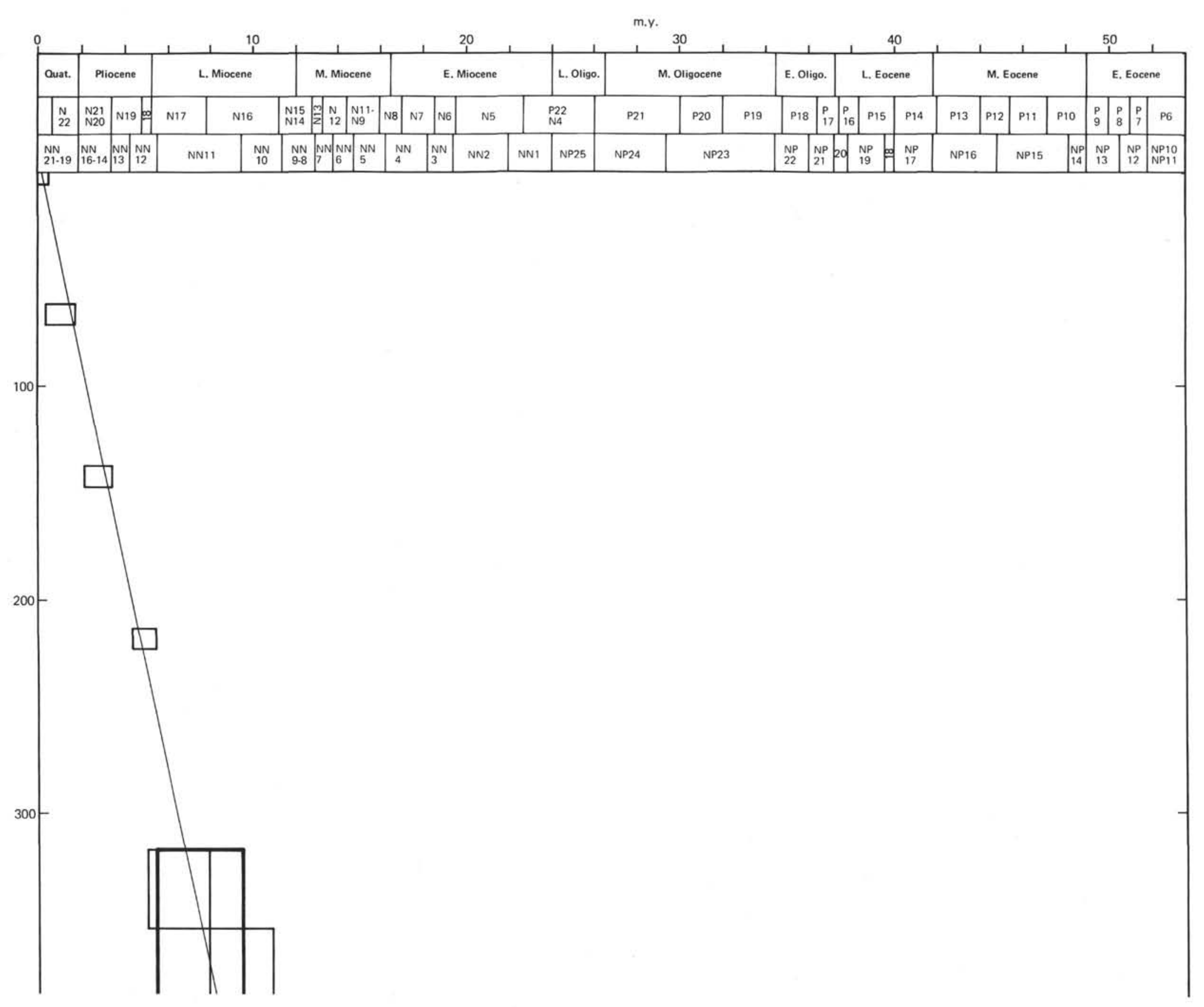




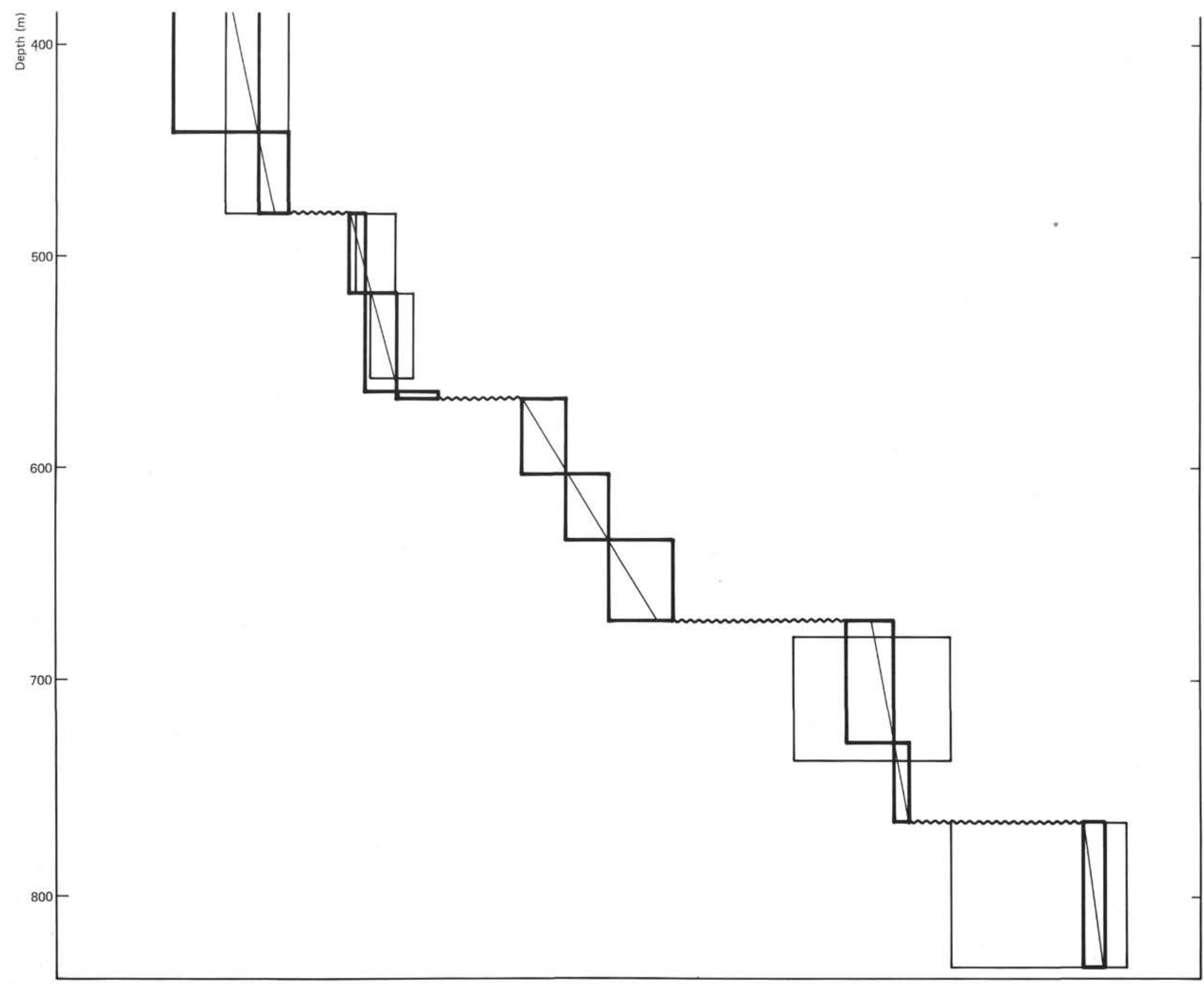


END OF

$\checkmark$ SONOBUOY LAUNCHED

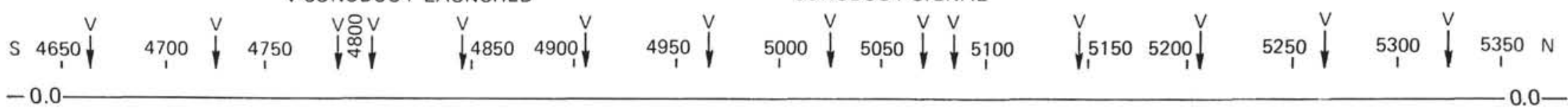

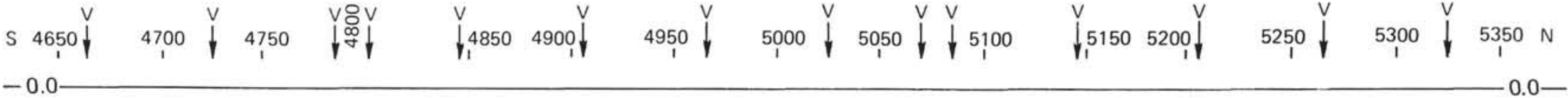

SONOBUOY SIGNAL

$-1.0$

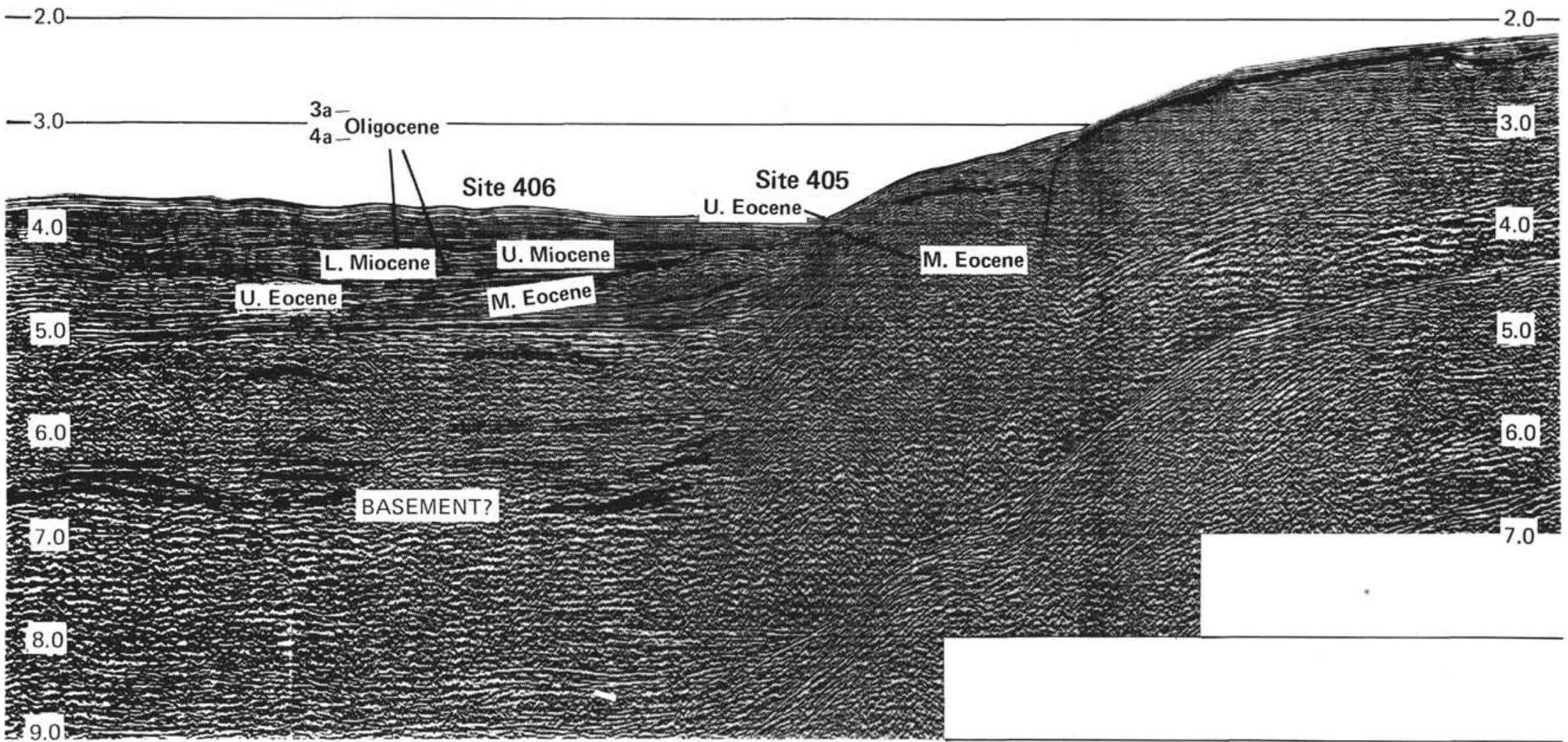

Figure 40. Multichannel seismic profile through Sites 405 and 406. 
upper middle Eocene limestones which also gives rise to reflector 4

Unit $5(765-822 \mathrm{~m})$ consists of brownish gray to gray marly calcareous chalk and limestone representing the uppermost part of the fan-like body observed on the seismic profiles. The carbonate content averages 32 per cent and the clay mineral content is almost entirely smectite. Variations in the palynological assemblages in different samples suggest instability in ocean circulation patterns whereas variable preservation indicates mixing of contemporaneous populations and transport of shelf sediments into deeper water (Costa and Downie, this volume).

\section{Depositional History}

The oldest sediments observed on the seismic profile through Sites 405 and 406 comprise an interval of strong flat-lying reflectors that infill the irregular oceanic basement. These sediments and the overlying strong reflector 5 were not penetrated at either site. Downward extrapolation of sedimentation rates (Figures 38, 39) suggests that reflector 5 is early Eocene in age (equivalent to anomaly-24) and the oceanic basement is inferred to be Paleocene in age from magnetic anomaly and regional tectonic considerations (Roberts et al., this volume). The 3 $\mathrm{km}$ of sediment thickness between reflector 5 and the oceanic basement below were therefore deposited entirely between the Paleocene and the Eocene, and are thus at least partly contemporaneous with the sediments at Sites 403 and 404. The Paleocene/Eocene sediments of Sites 405 and 406 were deposited on oceanic crust accreting to the south of the transform fault. In contrast, the contemporaneous sediments of Sites 403 and 404 were deposited in a rifting basin on continental crust. The lithology of these sediments is not known, but they are inferred to be volcaniclastic from high interval velocities (ca. $3+3.5 \mathrm{~km} / \mathrm{s}$ ) and the lithology of the contemporaneous beds at Sites 403 and 404. The rapid sedimentation at all four sites may reflect subaerial erosion of the rift highlands of the Rockall Plateau. The very strong reflector 5 may be caused by extrusives associated with the onset of spreading between Greenland and Rockall at anomaly-24 time (52 m.y.) (Hailwood et al., this volume). During post-early Eocene time, a large fan composed of claystones prograded outward in epibathyal depths from the base of the scarp. The existence of epibathyal depths at both sites in middle Eocene time places several constraints on the history of vertical tectonic movements along the transform scarp. Since the post-Eocene section is not faulted in either area, it is clear that a large part of the scarp must have been subaerial in middle Eocene time. The seismic profile and the paleobathymetric data suggest a total relief of $2.6 \mathrm{~km}$ of which at least $1.6 \mathrm{~km}$ were subaerial. Since middle Eocene time, the continental and oceanic crust on either side of the transform have remained coupled and have subsided to their present depths. These data apply only to the post-middle Eocene history, but it is clear from the regional geological data (Roberts et al., this volume) that the transform fault was created in the Late Cretaceous (anomaly 31-32 time) and remained active until $52 \mathrm{~m} . \mathrm{y}$. when the spreading axis passed beyond the trailing edges of the continents. The seismic data indicate a further $1.8 \mathrm{~s}$ of relief (approximately $3.0 \mathrm{~km}$ ) below reflector 5 . Since the post-reflector 5 sequence is not faulted, a relief of about $5.5 \mathrm{~km}$ along the fault was created by Eocene time. It is, therefore, inferred that vertical decoupling of the continent-ocean boundary, in addition to horizontal decoupling, took place along the transform during Late Cretaceous/Eocene time.

The inferences made above suggest that the scarp was subjected to subaerial erosion. The bevelled surface of the scarp crest may be an erosion surface and the fan itself may have been supplied by the sediments eroded from the scarp. Proximity to the shelf in middle Eocene time is indicated by mixtures of bathyal and shelf species and by palynological assemblages indicative of fluctuating shelf environments. The abundance of biogenic silica in the fan sediments drilled at the base of the scarp may indicate local upwelling . However, marly chalks and gray limestones that comprise the upper part of the fan at Site 406 show a decrease in biogenic silica with increasing distance from the scarp.

Reflector 4 defining the top of the fan marks a hiatus between the upper Eocene and middle Eocene at Site 406 and a prolonged hiatus between the middle Eocene and upper Miocene at Site 405. The more complete section at Site 406 includes hiatuses between the upper and middle Miocene, within the lower Miocene and between the middle Oligocene and upper Eocene. These hiatuses and the associated lithological changes may bear a close relationship to events in the evolution of the North Atlantic circulation from the Eocene to the present.

The middle to upper Eocene hiatus was associated with erosion rather than nondeposition because burrows unfilled with intra middle to upper Eocene sediments are found in the uppermost middle Eocene. The erosional event can be ascribed to an intensification of deep bottom water circulation associated with the cooling recorded by the oxygen isotope data (Létolle et al., this volume). The upper Eocene/Oligocene section was deposited in epibathyal depths but is dominated by slumping and the presence of diatomites. The slumps, which contain reworked Upper Cretaceous dinocysts and lower Eocene sediments, may be related to erosion associated with subsidence of the Rockall Plateau although the intensified circulation also may have contributed. The intensified steep dips recorded in the middle Eocene of Site 405 may also be related to the subsidence. Interbedded sequences of diatomites or siliceous chalk and calcareous chalks are common and may indicate upwelling against the fault scarp. The middle/upper Oligocene hiatus is associated with a change in the palynological assemblage from one with little affinity to Europe to one having a close affinity with the Norwegian Sea (Costa and Downie, this volume). The change may indicate the initiation of the exchange of water between the Norwegian Basin and the North Atlantic (Ducasse and Peypouquet, this volume). In the lower Miocene/Oligocene section, diatoms often comprise as much as 60 per cent of the diatomaceous chalk indicating that oceanographic conditions favored blooms of diatoms. In post-early Miocene time, biogenic silica production declined abruptly and the sediments were deposited in lower bathyal to abyssal depths. The fine parallel wavy and contorted laminae that characterize the Pliocene/middle Miocene section may reflect the influence of ocean bottom currents that is clearly shown on the seismic reflection profile 
(Roberts et al., this volume). A circulation change associated with the decrease in bottom temperature near the N.15 Zone may result in the absence of the N.15 Zone between the middle and upper Miocene (Létolle et al.; Müller, both, this volume). Warmer surface temperatures during the late Miocene may be partly responsible for the decline in biogenic silica production. It should be noted that at Site 405 sediments representing the interval from middle Eocene to late Miocene time are absent, which indicates that a current strong enough to inhibit deposition, and perhaps erode, has flowed over Site 405 since middle Eocene time. Erosion clearly can be seen at the level of reflector 4 between shotpoints 4950 and 5050. The existence of a marginal channel adjacent to the scarp, and underlain by a thinner post-upper Miocene section, suggests that the current may have flowed along the base of the scarp and perhaps been accelerated by the local topography (Roberts, 1975).

Since Pliocene time, the facies at both sites reflect the increasing and continuing importance of glaciation of the Northern Hemisphere. A further nondepositional and/or erosional event took place in intra Miocene/Pleistocene time resulting in the absence of the Pliocene at Site 405 .

\section{REFERENCES}

Costa, L.I. and Müller, C., 1978. Correlation of Cenozoic dinoflagellate and nannoplankton zones from the NE Atlantic and NW Europe, Newsl. Stratig., v. 7, p. 65-72.

Jones, M. T. and Roberts, D. G., in preparation. Marine magnetic anomalies in the eastern North Atlantic Ocean.

Laughton, A. S., 1971. South Labrador Sea and the evolution of the North Atlantic, Nature, London, v. 232, p. 612-617.

Le Pichon, X., Hyndman, R., and Pautot, G., 1972. Geophysical study of the opening of the Labrador Sea, J. Geophys. Res., v. 73, p. $7637-7649$.

Olivet, J. L., Le Pichon, X., Monti, S., and Sichler, B., 1974. Gibbs Fracture Zone, J. Geophys. Res., v. 79, p. 2059-2072.

Roberts, D. G., 1971. New geophysical evidence on the origins of the Rockall Plateau and Trough, Deep-Sea Res., v. 18, p. 353-359.

, 1974. Structural development of the British Isles, continental margin and the Rockall Plateau. In Bark, C. A. and Drake, C.L. (Eds.), The geology of continental margins: New York (Springer-Verlag), p. 343-359.

1975. Marine Geology of the Rockall Plateau and Trough, Phil. Trans. Roy. Soc. London, v. 278, p. 447-509.

Roberts, D. G., Ardus, D. A., and Dearnley, R. A., 1973a. Pre-Cambrian rocks drilled from the Rockall Bank, Nature Phys. Sci., v. 244, p. 21-23.

Roberts, D. G., Flemming, N. C., Harrison, R. K., and Bonns, P., 1973b. Helen's Reef: A Cretaceous microgabbroic intrusion in the Rockall intrusive center, Mar. Geol., v. 16, M21-M30.

Ruddiman, W. B., 1972. Sediment distribution on the Reykjanes Ridge: seismic evidence, Geol. Soc. Am. Bull., v. 83, p. 2039-2062.

Vogt, P. R., Johnson, G. L., Holcombe, T. L., Gilg, J. G, and Avery, O. E., 1971. Episodes of sea-floor spreading recorded by the North Atlantic basement, Tectonophysics, v. 12, p. 211-234.

Vogt, P. R. and Avery, O. E., 1974. Detailed magnetic surveys in the Northeast Atlantic and Labrador Sea, J. Geophys. Res., v. 79, p. 363-389.

\section{APPENDIX}

\section{PETROGRAPHY OF SOME PEBBLE FRAGMENTS FROM DSDP LEG 48, SITE 405, SOUTHWEST MARGIN OF ROCKALL PLATEAU}

R. R. Harding, Institute of Geological Sciences, London, United Kingdom

\section{INTRODUCTION}

Pebble fragments (Table $i$ ) from Leg 48, Site 405, Cores 19, 23, and 25-29 were identified petrographically for comparison with possible source areas, and for evidence of mode of deposition. The cores are of early Eocene age ( $W$. coleothrypta Zone) (Costa and Downie, this volume).

\section{PETROGRAPHY}

Sample 405-19-1, 1-3 cm. Gneiss. Andesine and quartz occur as anhedral grains in a granitoid texture, with golden to pale brown biotite flakes commonly showing a preferred orientation. Subrounded zircon is present in both biotite and plagioclase and opaque grains are included in plagioclase or associated with biotite and chlorite. There are minor amounts of augite, garnet, and muscovite.

Sample 405-23-1, 6-8 cm. Pyroxene granulite. Anhedral plates of hypersthene containing thin lamellae parallel to (100) are commonly associated with granular clinopyroxene, most of which shows sharp, curved boundaries against quartz and plagioclase. Flakes of golden brown to pale yellow biotite lie interstitially to the above minerals, in places being marginally altered to green chlorite. The plagioclase is andesine with slight normal zoning to more sodic rims. Some grains show shadowy extinction.

Sample 405-25-1, 6-8 cm. Gneiss. A gray leucocratic rock, with anhedral plagioclase and quartz comprising 80 per cent of the volume, with subsidiary biotite, muscovite, microcline, opaque oxides, apatite, sphene, zircon, and epidote. Zircons $(0.05 \mathrm{~mm})$ and apatite $(0.15 \mathrm{~mm})$ have rounded outlines and generally rest in quartz or plagioclase hosts, although a few zircons are interstitial and some exhibit overgrowths. The texture varies between granitoid and granulitized, the latter occurring in elongate zones and probably associated with alteration processes causing development of epidote, sphene, and muscovite.

Sample 405-25-1, 10-12 cm. Gneiss. Hornblende and plagioclase are the two main minerals. The hornblende is an intense green to pale yellow-green pleochroic variety, subhedral to anhedral and poikilitic in parts, with inclusions of quartz, apatite, or zircon. The anhedral, lamellar-twinned grains of oligoclase are partly altered to sericite and are separated from some hornblende crystals by thin reaction rims. Sphene and chlorite are associated in patches, the shapes of which indicate that they formed at the expense of biotite. Quartz is most apparent as rounded inclusions in both hornblende and plagioclase, but it also occurs in the matrix of the rock which has an overall granoblastic texture.

Sample 405-25-1, 17-19 cm. Porphyritic basalt. Phenocrysts of labradorite and smaller phenocrysts of ?bastite pseudomorphous after olivine or orthopyroxene rest in a fine-grained $(0.01-0.1 \mathrm{~mm})$ granular

TABLE $i$

Pebble Samples From Lower Eocene Cores, Leg 48, Site 405

\begin{tabular}{lcl}
\hline \multicolumn{1}{c}{$\begin{array}{c}\text { Sample } \\
\text { Interval in cm) }\end{array}$} & $\begin{array}{c}\text { Depth Below Sea } \\
\text { Floor }(\mathrm{m})\end{array}$ & \multicolumn{1}{c}{ Rock Type } \\
\hline $19-1,1-3$ & $170.01-170.03$ & Gneiss \\
$23-1,6-8$ & $208.06-208.08$ & Pyroxene granulite \\
$25-1,6-8$ & $227.06-227.08$ & Gneiss \\
$25-1,10-12$ & $227.10-227.12$ & Gneiss \\
$25-1,17-19$ & $227.17-227.19$ & Porphyritic basalt \\
$26-1,3-5$ & $236.03-236.05$ & Granitic gneiss \\
$26-1,18-20$ & $236.18-236.20$ & Hornblende granulite \\
$27-1,4-6$ & $246.04-246.06$ & Granitic gneiss \\
$27-1,9-11$ & $246.09-246.11$ & Gneiss \\
$28-1,4-6$ & $255.04-255.06$ & Porphyritic basalt \\
$28-1,7-9$ & $255.07-255.09$ & Gneiss \\
$28-1,13-15$ & $255.13-255.15$ & Metamorphosed dolerite \\
$29-1,5-7$ & $265.05-265.07$ & Impure limestone \\
& & \\
\hline
\end{tabular}


matrix of andesine, augite, and opaques. In parts, the augite and andesine are subophitic. There are a few patches of partly devitrified olive-green glass, and analcime is also present.

Sample 405-26-1, 3-5 cm. Granitic gneiss. Plagioclase (andesine and oligoclase) is intergrown with microcline and quartz in a granitic texture and is variably sericitized or saussuritized. Green to pale green pleochroic hornblende has been extensively altered to biotite, clinozoisite, quartz, calcite, opaques, and sphene with a development of sieve texture in parts. Perthite and microcline mantle plagioclase and mafic clusters with quartz filling the interstices. Apatite is a common inclusion in hornblende, biotite, and opaque minerals.

Sample $405-26-1,18-20 \mathrm{~cm}$. Hornblende-granulite. This rock is a porphyroblastic hornblende-biotite-granulite with large crystals and augen of oligoclase and microcline resting in a matrix of subhedral to anhedral grains of the same minerals. The hornblende is dark green, and biotite shows dark brown to pale yellow pleochroism. Rounded quartz grains and opaques of various shapes, with accessory rounded and prismatic apatite and rounded zircons comprise the remainder of the rock.

Sample 405-27-1, 4-6 cm. Granitic gneiss. Sericitized plagioclase, microcline, and quartz make up 90 per cent of the rock in a granitic texture which has been granulitized along discrete zones. Sparse clusters of mafic minerals consist of opaques, biotite, chlorite, and a little clinozoisite, and one cluster consists of a sieve-textured hornblende with inclusions of quartz, clinozoisite, and olive-green biotite. Rounded zircons, some with complex overgrowths, prisms of apatite, and calcite are accessory minerals.

Sample 405-27-1, 9-11 cm. Gneiss. Green to pale yellow pleochroic hornblende in clusters of coarse interlocking crystals; it contains a few inclusions with brown haloes and is variably bleached and altered (first along cleavages) to biotite, clinozoisite, or calcite. Andesine, in similar-sized crystals, is patchily replaced by euhedral clinozoisite, calcite, and ?chlorite and, with quartz, it forms a granoblastic matrix to the hornblende clusters. The quartz is crowded with clinozoisite grains.

Sample 405-28-1, 4-6 cm. Porphyritic basalt. Rare phenocrysts of pale brown augite with a thin outer, deeper brown zone, and abundant microphenocrysts of colorless orthopyroxene, brown augite, and labradorite rest in a groundmass of intergranular plagioclase, pyroxene and opaques. Some plagioclase laths have "swallowtail" terminations, and some have axial zones of intergranular mesostasis. Glass is present interstitially.

Sample 405-28-1, 7-9 cm. Gneiss. Large anhedral andesine crystals in a granitoid texture have been granulitized in zones with development of variable strain shadows and exsolution of quartz in plates along the cleavage planes. Orthopyroxene (probably hypersthene) is largely fresh, but many grains are bent or cracked and some alteration to biotite has occurred along cleavages. Accessory apatite and zircon are found mainly in plagioclase hosts, and subhedral opaques are generally associated with the orthopyroxene. Quartz occurs in granulitic and suture-textured zones.
Sample 405-28-1, 13-15 cm. Metamorphosed dolerite. The original intergranular and subophitic texture of a two-pyroxene dolerite is recognizable even though the orthopyroxene has altered to golden brown mica or chlorite and the clinopyroxene to green amphibole; clusters of garnet euhedra have grown at the expense of plagioclase and orthopyroxene. The labradorite and andesine are clouded and a later phase of alteration has caused development of pale green amphibole and opaques with some introduction of calcite.

Sample 405-29-1, 5-7 cm. Impure limestone. Abundant coccoliths, foraminifers, siliceous sponges, spicules, anhedral opaque grains, glauconite, and flakes of chlorite and other clay minerals rest in a very fine $(0.001 \mathrm{~mm})$ matrix of specks of carbonate and low-birefringent material which is probably silica. The following nannoflora was identified by Dr. A. W. Medd:

$\begin{array}{ll}\text { Neococcolithes dubius (Deflandre) } & \text { Jurassic to NP } 18 \\ \text { Transversopontis prava Locker } & \text { NP 15-NP 17 } \\ \text { Ericsonia } \text { sp. } & \text { Eocene } \\ \text { Clathrolithus spinosus } \text { Martini } & \text { NP 16-NP 19 } \\ \text { Blackites spinosus/creber plexus } & \text { L/M Eocene } \\ \text { Reticulofenestra } \text { cf. umbilica (Levin) } & \text { NP 15-NP 22 } \\ \text { Chiasmolithus eograndis/solitus plexus } & \text { NP 12-NP 14 } \\ \text { Micrantholithus mirabilis Locker } & \text { NP 11-NP 12 }\end{array}$

\section{DISCUSSION}

The fragments consist of orthogneisses, paragneisses, basic volcanic rocks, and an impure limestone. Dr. A. W. Medd concluded that the nannoflora of Sample 405-29-1,5-7 cm, is a mixture of NP 12 and NP $15 / 16$ elements with no discoasterids having been found to confirm either of these dates. This single sample cannot be used as a reliable indication of age of the pebble because two hypotheses to account for its features, namely reworking or downhole contamination, seem to be equally likely. The ortho- and paragneisses represented by 10 of the above specimens all have analogs in the Outer Hebrides and Scottish mainland; in particular, Sample $405-28-1,13-15 \mathrm{~cm}$ is considered by Dr. R. Dearnley (personal communication) to resemble closely the Scourie dykes in the Outer Hebrides (at a slightly lower metamorphic grade than those on the mainland). The two porphyritic basalts possess no obvious features which would indicate their source; both are similar to types found on the Isle of Skye and in northern Ireland in Tertiary provinces. There was poor recovery of material from these cores and because no matrix adheres to the pebbles, the evidence of the type of sediment in which the pebbles were deposited is missing. Three groups of pebbles have been distinguished: those derived from basic igneous, sedimentary, and high-grade metamorphic sources, but important factors bearing on the origin of the deposit are not known and for this reason age determinations of the pebbles were not made. The time of their deposition remains an open question. 